\title{
From river to shelf, anatomy of a high-frequency depositional sequence: The Late Pleistocene to Holocene Tiber depositional sequence
}

\author{
SALVATORE MILLI*, MARCO MANCINI†, MASSIMILIANO MOSCATELLI†, \\ FRANCESCO STIGLIANO $\uparrow$, MATTIA MARINI $\$$ and GIAN PAOLO CAVINATO $\dagger$ \\ *Dipartimento di Scienze della Terra, SAPIENZA Università di Roma, Piazzale Aldo Moro 5, 00185 \\ Roma, Italy (E-mail: salvatore.milli@uniroma1.it) \\ $\dagger$ CNR-IGAG Istituto di Geologia Ambientale e Geoingegneria, Via Salaria km 29,300, 00015 \\ Monterotondo (RM), Italy \\ ¥Dipartimento di Scienze della Terra “Ardito Desio”, Università di Milano, Via Mangiagalli 34, 20133 \\ Milano, Italy
}

Associate Editor - David Mohrig

\begin{abstract}
The Late Pleistocene/Holocene Tiber delta succession represents the most recent and one of the best preserved, high-frequency/low-rank depositional sequences developed along the Latium continental margin of the Italian peninsula. Several previous studies have established a robust data set from which it has been possible to describe the stratigraphic architecture of the entire Tiber depositional sequence from the landward to seaward sectors and over a distance of $60 \mathrm{~km}$. The Tiber depositional sequence shows many characteristics found in other Late Pleistocene to Holocene deltaic and coastal successions of the Mediterranean area. The stratigraphic architecture of the Tiber depositional sequence is controlled mainly by glacioeustasy, although factors such as tectonic uplift, volcanism and subsidence, exert an influence at a local scale. The resulting depositional model allowed discussion of some important points such as: (1) the genesis of the Tiber mixed bedrock-alluvial valley, extending from the coastal plain to the innermost portion of the shelf, recording (i) multiple episodes of incision during relative sea-level fall, and (ii) a downstream increase of depth and width of the valley during the base-level fall and the subsequent base-level rise; (2) the different physical expression of the Tiber depositional sequence boundary from landward to seaward, and its diachronous and composite character; (3) the maximum depth reached by the Tiber early lowstand delta at the end of the sea-level fall is estimated at $c a 90 \mathrm{~m}$ below the present sea-level and not at $120 \mathrm{~m}$ as suggested by previous works; (4) the backward position of the Tiber late lowstand delta relative to the deposit of early lowstand; (5) the change of the channel pattern and of the stacking pattern of fluvial deposits within the Lowstand Systems Tract, Transgressive Systems Tract and Highstand Systems Tract. All of these features indicate that the Late Pleistocene/ Holocene Tiber delta succession, even if deposited in a short period of time from a geological point of view, represents the result of the close interaction among many autogenic and allogenic factors. However, global eustatic variations and sediment supply under the control of climatic changes can be considered the main factors responsible for the stratigraphic architecture of this sedimentary succession, which has been heavily modified by human activity only in the last 3000 years.
\end{abstract}


Keywords High-frequency depositional sequences, significance of sequence boundary, Tiber delta succession, Upper Pleistocene-Holocene, wave-dominated delta, wave-dominated estuary.

\section{INTRODUCTION}

The Quaternary high-frequency depositional sequences are certainly the better-preserved stratigraphic units in the geological record, where it is possible to discriminate the effects related to the pervasive glacio-eustatic sea-level fluctuations from other factors, such as tectonics and climate. This is particularly true for the deposits of the coastal depositional systems, where interactions among relative sea-level changes, sediment supply and marine processes are better-recorded (Boyd et al., 1992). This interaction is particularly well-recorded in the Late Pleistocene and Holocene deposits, within which all systems tracts of the high-frequency sequences have a high probability of preservation. Moreover, the stacking pattern of the systems tracts is simple to read and allows better evaluation of how they respond to the rapid sealevel fluctuations and sediment supply and, in particular, how fluvial accommodation develops during the late lowstand, transgressive and highstand systems tracts (see for example, Posamentier \& Allen, 1999; Holbrook and Bhattacharya, 2012; Blum et al., 2013). Such evidence has been recognized in several Late Pleistocene and Holocene successions in different parts of the world such as the Australian coast (Thom, 1983; Thom \& Roy, 1985; Evans et al., 1992; Roy, 1994), the Brazilian coast (Dominguez et al., 1987; Dominguez \& Wanless, 1991), Japan (Saito, 1994), and the Korea Strait (Yoo \& Park, 2000), the south-east Asian coast (Dalrymple et al., 2003; Robert and Sydow, 2003; Reijenstein et al., 2011) and the Atlantic and Gulf coasts of the United States (Rampino \& Sanders, 1980; Demarest \& Kraft, 1987; Suter et al., 1987; Penland et al., 1988; Belknap et al., 1994; Blum, 1994; Nichol et al., 1994, 1996; Sydow \& Roberts, 1994; Thomas \& Anderson, 1994; Morton \& Suter, 1996; McBride et al., 1999; Anderson et al., 2004), where they show remarkable similarities with respect to the organization of late Quaternary depositional sequences.

In the Mediterranean area, the Late Pleistocene and Holocene sedimentary successions of the main deltas such as the Nile (Coutellier \&
Stanley, 1987; Sestini, 1989; Stanley \& Warne, 1994), the Rhône (Oomkens, 1970; Tesson et al., 1990, 1993; Gensous et al., 1993; Torres et al., 1995; Gensous \& Tesson, 1996, 1998; Boyer et al., 2005; Labaune et al., 2005), the Ebro (Díaz et al., 1990; Somoza et al., 1998), the Alboran Sea (Ercilla et al., 1994; Hernández-Molina et al., 1994, 1996) and, in Italy, the Po (Nelson, 1970; Amorosi et al., 1999, 2003, 2004, 2005; Amorosi \& Milli, 2001; Amorosi \& Colalongo, 2005), the Tiber (Belluomini et al., 1986; Bellotti et al., 1994, 1995, 2007; Milli, 1997; Amorosi \& Milli, 2001; Giraudi, 2004; Di Bella et al., 2013; Milli et al., 2013), the Ombrone (Bellotti et al., 1999, 2004; Bellotti, 2000; Tarragoni et al., 2011), the Campania coastal plain (Barra et al., 1992; Ortolani \& Pagliuca, 1999) and the Arno (Aguzzi et al., 2007; Amorosi et al., 2008, 2013) rivers show remarkable similarities in terms of stratigraphic evolution. Nevertheless, none of these systems has been the subject of correlations between the internal (fluvial sector) and the external portions (coastal and marine sectors), nor analysis of how these sectors respond to relative sea-level fall and rise, and to variations in sediment supply. Thus, the importance of research on the Tiber depositional sequence (TDS) resides in the fact that it was possible, for the first time, to have a detailed correlation of $c a 60 \mathrm{~km}$ from the internal to the external portions (from land to sea) of a high-frequency depositional sequence. This correlation constitutes a powerful tool that can be used in sequence-stratigraphic studies and shows how the concepts of sequence stratigraphy are valid and powerful to analyse the sedimentary successions.

The detailed investigations carried out in the last two decades in the Tiber delta area (see previous literature) documented how the sedimentary dynamics and the stratigraphic architecture of the Late Pleistocene and Holocene succession (the TDS) was strictly controlled by glacioeustatic sea-level changes and by a concomitant action of the volcanism and tectonics (Milli, 1997; Milli et al., 2008). These factors, in turn, controlled the position and orientation of the Tiber-incised valley and delta mouth, as well as 
the tributary rivers flowing into the Tiber. The research also recognized that forcing factors controlling the architecture of the TDS (climate, sediment supply, accommodation space, marine processes, and density differences between effluent and receiving waters) varied in time and space during the sea-level fall and rise, thus allowing to record, in the examined succession, a change from a wave-dominated estuary to a wave-dominated delta (Amorosi \& Milli, 2001; Milli et al., 2013).

Although most of the data presented here have been discussed through the years (Bellotti et al., 1989, 1994, 1995, 2007, 2009, 2011; Chiocci \& Milli, 1995; Milli, 1997; Amorosi \& Milli, 2001), only recently have other investigations been conducted in the inland and offshore sectors of the Tiber River (Di Bella et al., 2013; Mancini et al., 2013; Milli et al., 2013), allowing detailed reconstruction of the architecture of the entire depositional sequence of the Tiber for almost $60 \mathrm{~km}$ from land to sea.

The purpose of this article is to provide a useful and documented example of a complete high-frequency depositional sequence developed on a time interval of $150 \mathrm{ka}$, described from the internal fluvial sectors to the external coastal and shelfal sectors. As such, the entire Late Pleistocene to Holocene Tiber succession represents a detailed depositional model, recording the transition from a wave-dominated estuary to a wave-dominated delta, which can be utilized as a subsurface analogue. In addition, the several stratigraphic cross-sections may allow definition of three-dimensional (3D) volumes within which the lithofacies distribution, the depositional geometry and the small-scale to largescale permeability pattern can be reconstructed. Furthermore, when the petrophysical properties are available, 2D seismic modelling can be undertaken to obtain a simulated seismic section which can be used in order to image the most likely seismic features of the internal hydrocarbon or water reservoir geometry (Marini et al., 2013), and as a model for hydrostratigraphy and geohazard evaluation (subsidence, soil settlement and local seismic response).

\section{GEOLOGICAL AND SEQUENCE- STRATIGRAPHIC SETTING}

The Tiber delta lies on the central coastal sector of the Latium region (central Italy), south-west of Rome. It extends along the coast for approxi- mately $38 \mathrm{~km}$ and is considered to be a wavedominated delta (Bellotti et al., 1994; Fig. 1). The Tiber River supplying the delta is $405 \mathrm{~km}$ long and has a drainage basin of $c a 17000 \mathrm{~km}^{2}$, which includes part of the central-northern Apennines and the volcanic area of Latium, where carbonate, siliciclastic and volcanic rocks are exposed.

The Tiber delta develops along the Tyrrhenian margin of the Italian peninsula, a margin that has been affected by extensional processes since the upper Miocene as a consequence of the progressive eastward shifting of the west-directed Apennine subduction (Malinverno \& Ryan, 1986; Patacca et al., 1990; Doglioni et al., 2004). Starting from the Miocene, the extensional tectonics migrated eastward from the Tyrrhenian area to the Apennines divide where, at present, the boundary between two different domains is located: compressional to the east and extensional to the west (Cavinato \& De Celles, 1999; D'Agostino et al., 2001).

The Tyrrhenian extensional margin of central Italy is characterized by the presence of northwest/south-east normal faulting and of coeval north-east/south-west transverse systems. Both systems have played an important role in controlling the Plio-Quaternary volcanism (Acocella \& Funiciello, 2006 and references therein; Fig. 2). The north-west/south-east normal faults are also responsible for the development of several subparallel Plio-Quaternary extensional basins, whose continuity is often interrupted by the north-east/south-west fractures. The latter are interpreted as transfer faults of the northwest/south-east normal faults (Acocella \& Funiciello, 2006) and give rise to a series of transverse extensional basins. Both of these basins are filled with syn-rift and post-rift clastic sediments to which volcaniclastic deposits are associated (Funiciello et al., 1976; Mariani \& Prato, 1988; Cavinato et al., 1992; Barberi et al., 1994; Faccenna et al., 1994).

In the Latium area, the Roman basin (Conato et al., 1980) hosts the late Quaternary Tiber succession, and extends north and south of the Tiber River for $c a 135 \mathrm{~km}$. The development of this basin started in the Late Pliocene and was accompanied by a continuous regional uplift (Milli, 1997; Bordoni \& Valensise, 1998; Giordano et al., 2003; Mancini et al., 2007) and by intense volcanic activity, which reached its climax in the Middle-Late Pleistocene when the volcanic complexes of the Magmatic Roman Province developed (Locardi et al., 1976; Fornaseri, 


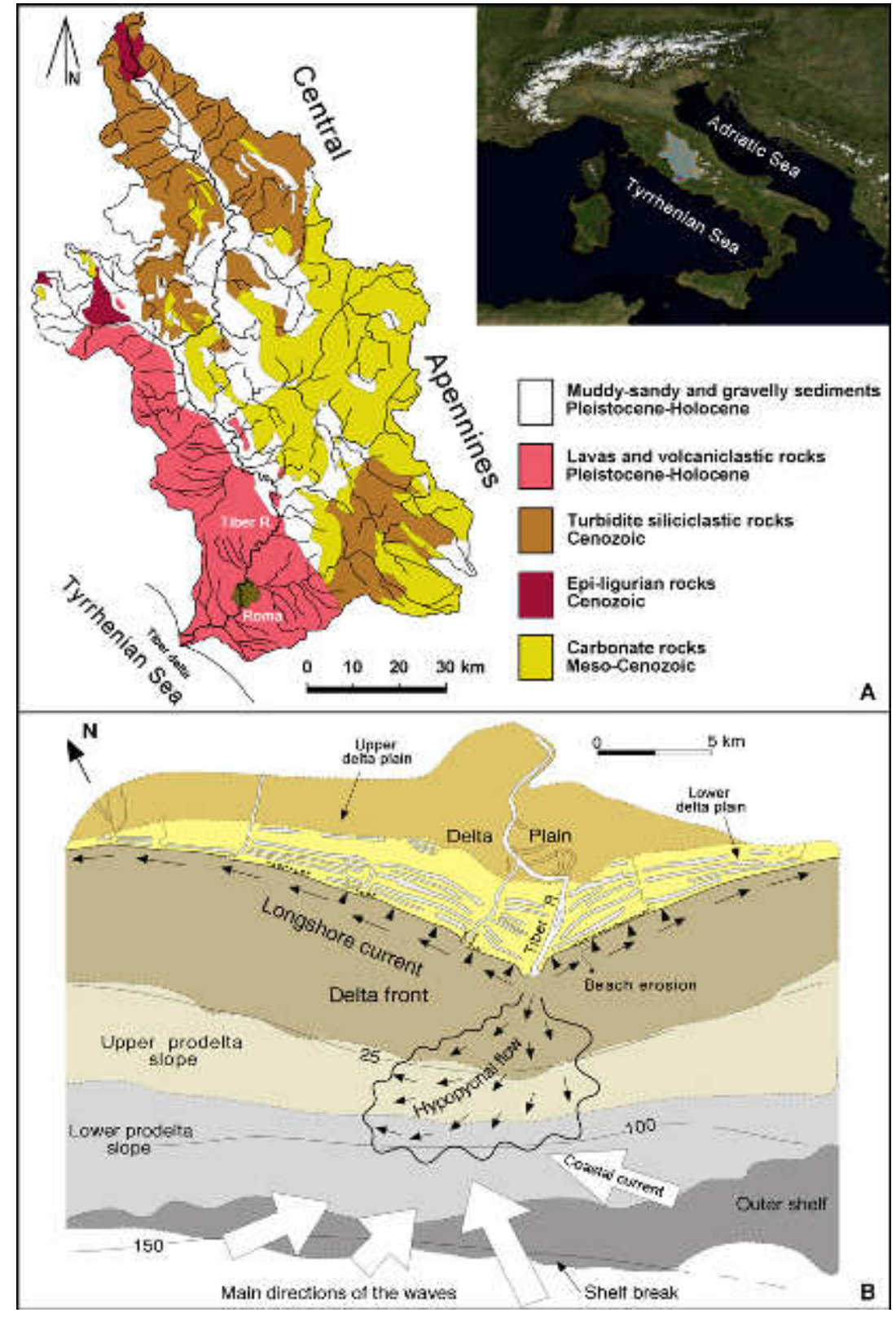

Fig. 1. (A) Drainage basin of the Tiber River and main outcropping rocks. (B) Main depositional processes of the wave-dominated Tiber delta (modified from Bellotti et al., 1994). Metres below presentday sea-level.
1985; Cioni et al., 1993; De Rita et al., 1993, 1995; Karner et al., 2001; Peccerillo, 2005).

The stratigraphic framework of the Roman basin is the result of the close interaction between tectonic uplift, volcanic activity and glacioeustatic sea-level fluctuations (Cavinato et al., 1992; De Rita et al., 1994, 2002; Milli, 1994, 1997; Giordano et al., 2003; Mancini \& Cavinato, 2005; Milli et al., 2008, and references therein). The stratal architecture of this basin is characterized by several depositional units constituting low rank (high-frequency) depositional sequences (sensu Mitchum \& Van Wagoner, 1991; Catuneanu et al., 2009, 2011) with a duration variable from 30 to $120 \mathrm{kyr}$, stacked to form two composite high rank sequences named the Monte Mario Sequence (MMS: Lower Pleistocene) and Ponte Galeria Sequence (PGS: Late Lower PleistoceneHolocene), respectively (Milli, 1997; Milli et al., 2013, and references therein; Fig. 3).

The MMS deposits crop out in the study area with a limited extension (Monte Mario sector) and are essentially known through the stratigraphies of several wells. These deposits are known in the literature as the Monte Mario formation, a unit subdivided by Conato et al. (1980) into two informal members: the Monte Mario member and the Monte delle Piche member. Based on 
Fig. 2. Geological sketch of the Central Italy Tyrrhenian margin: (1) Messinian-Holocene sedimentary deposits; (2) Pliocene-Pleistocene lavas and volcaniclastic deposits; (3) Meso-Cenozoic sedimentary deposits; (4) main buried faults; (5) strike-slip faults; (6) normal faults; (7) major thrusts. The black square indicates the study area.

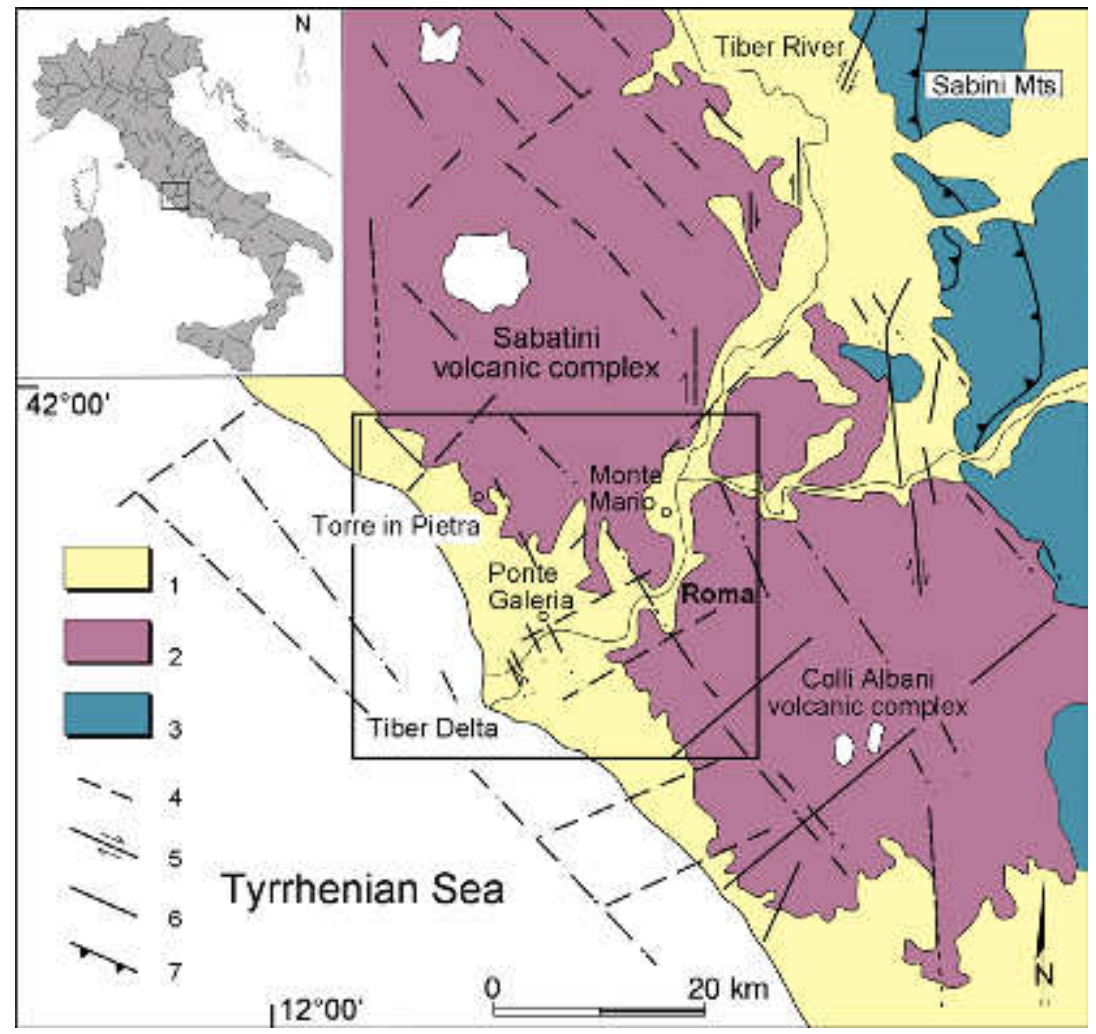

recent data derived by Milli (1997), Cosentino et al. (2009) and Di Bella (2010), it is suggested here that the delta deposits of the Monte Mario member belong to the Late Lowstand Systems Tract (LLST) of the MMS, while the transitionshelf deposits of the Monte delle Piche member belong to the Transgressive Systems Tract (TST) of the MMS (see stratigraphic scheme of the Roman basin proposed by Milli et al., 2013) (Fig. 3).

The PGS is more complete than the MMS, and contains fluvial, fluvio-palustrine-lacustrine, barrier island-lagoon and transition-shelf depositional systems, organized to constitute the lowstand systems tract (LST), the transgressive systems tract (TST) and the highstand systems tract (HST) of the PGS (Fig. 3). Volcaniclastic deposits belonging to the Albani and Sabatini volcanic complexes are interfingered with these sediments and together constitute the filling of tributary-incised valleys merging into the Tiber valley.

The PGS ranges in thickness from 10 to $110 \mathrm{~m}$, between the city of Rome and the Tyrrhenian Sea coastline. It lies above the shelfal mud sediments of the MMS through a diachronous and composite (polygenic) erosional surface, formed during the sea-level fall characterizing the inter- val time between Marine Isotope Stage (MIS) 31 and MIS 20 (Fig. 3). This high rank composite sequence consists of 12 low rank sequences, from 5 to $80 \mathrm{~m}$ thick (Fig. 3; Milli et al., 2013), the boundaries of which are represented by sharp erosional surfaces, recording basin and downward shift of facies, subaerial exposure and palaeosol formation in the interfluvial areas (Milli, 1997). As a whole, the low rank sequences form a complex stack of multiple-incised valleys (Milli, 1997; Milli et al., 2008, 2013), which essentially include bedrock-alluvial and coastal plain segments (sensu Blum et al., 2013), while shelf segments are not developed, except for short stretches in the innermost portion of the shelf (see The mixed bedrock-alluvial Tiber valley section).

The stratigraphic organization of the PGS shows that the oldest six low rank sequences (from PG01 to PG3) stack to form the LST of the PGS. Sequences from PG4 to part of PG8 are referable to the TST, while the sequence PG9 (the TDS) developed entirely during the HST of the PGS (Fig. 3; Milli et al., 2013).

The whole stacking pattern of the PGS shows a general trend characterized by a seaward stack of the low rank depositional sequences (Fig. 4). This trend is opposite to the trend that the PGS 


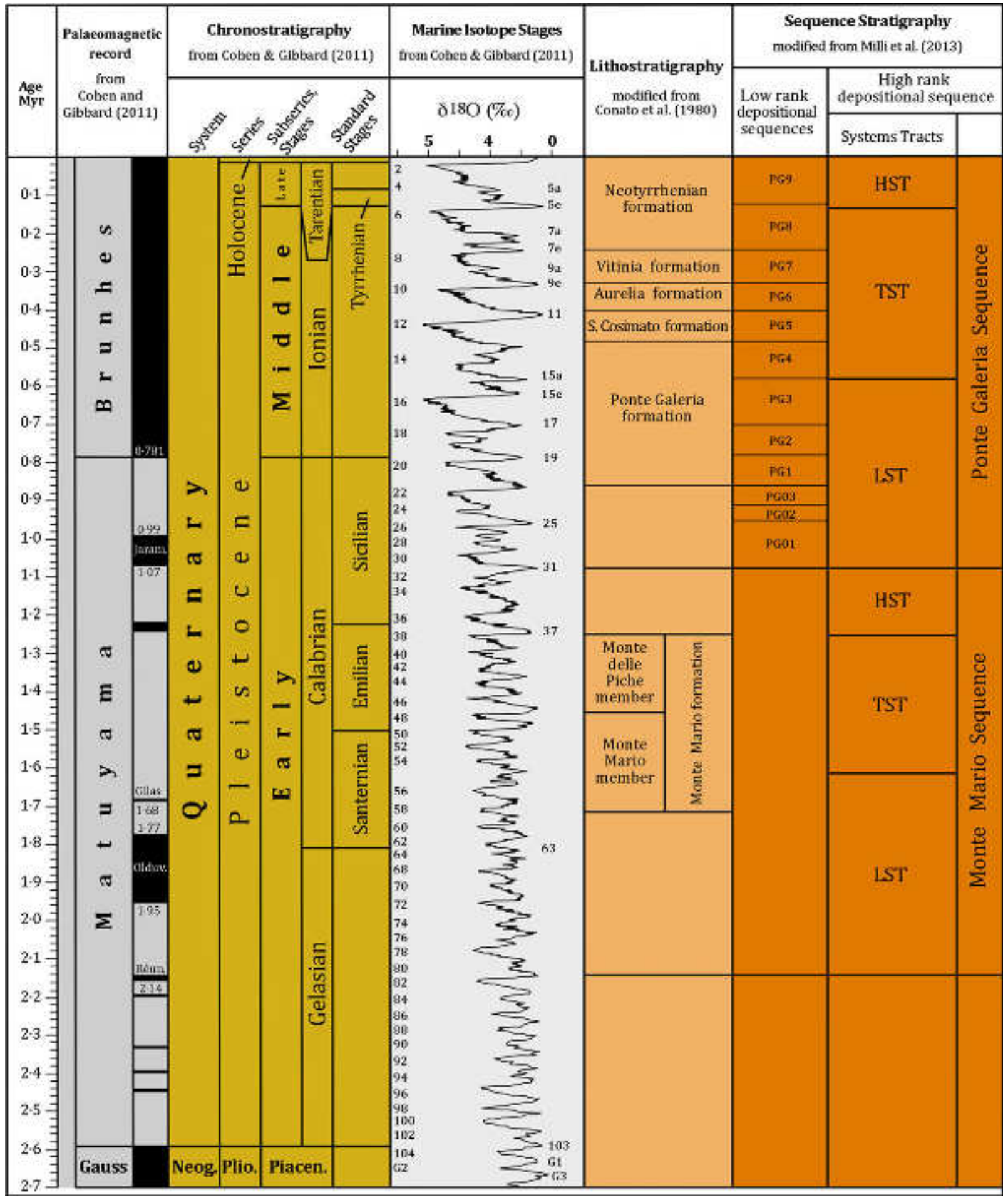

Fig. 3. Chronostratigraphic and sequence-stratigraphic scheme of the Quaternary deposits of the Roman basin (modified after Milli et al., 2013). HST, Highstand Systems Tract; TST, Transgressive Systems Tract; LST, Lowstand Systems Tract; PG, Ponte Galeria

would display if controlled by glacioeustasy alone. In this case, each low rank sequence should migrate progressively landward, confirm- ing the trend detectable on the eustatic curve (Haq et al., 1988; Hardenbol et al., 1998; Miller et al., 2005). On the contrary, the present setting 


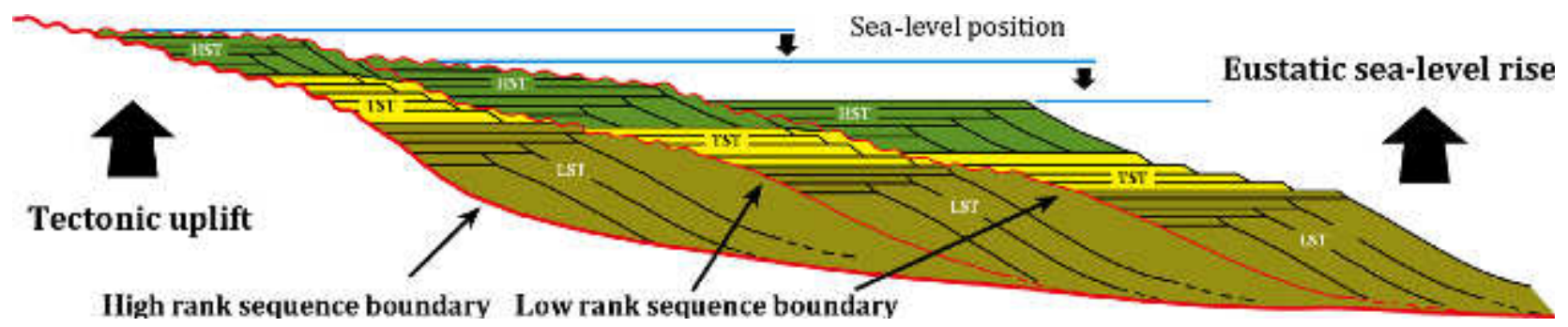

Fig. 4. Conceptual sketch showing the stratigraphic relationships among the low rank sequences within the Roman basin as related to the interaction between tectonic uplift of the Latium Tyrrhenian margin and eustatic sea-level changes during the development of the high rank Ponte Galeria Sequence. Note the downward and the seaward migration of the sequences as due to the tectonic uplift of the continental margin.

of the PGS is considered to be the result of the interaction of three main factors: (i) highfrequency sea-level fluctuations related to glacioeustasy; (ii) volcanic activity; and (iii) tectonic uplift that affected the eastern Tyrrhenian margin during the Middle-Late Pleistocene. The latter would have forced the seaward migration of the low rank sequences, thus contributing to define the final stacking pattern of the PGS (see more details and discussion in Milli, 1997; Milli et al., 2008).

\section{DATA AND METHODS}

The investigated area extends for $c a 60 \mathrm{~km}$ from land to sea, and covers the whole Tiber alluvial plain crossing the urban area of Rome within the GRA (Grande Raccordo Anulare) highway ring, the present delta plain and the submerged sector until the shelf edge (Fig. 5). Inland, the stratigraphic architecture of the TDS has been reconstructed utilizing a large database constituted by $c a 1200$ continuous coring boreholes, collected by public administration and private companies, which are uniformly well-distributed along the Tiber alluvial valley and on the Tiber delta plain. All of these boreholes are stored in the CNR-IGAG (Consiglio Nazionale delle Ricerche-Istituto di Geologia Ambientale e Geoingegneria) database (Fig. 5) and have been utilized by several authors over the years to study the Late Pleistocene/Holocene Tiber delta succession (see references). For the submerged sector, a high-resolution seismic profile extending from the Tiber mouth to the shelf break and three gravity cores, located on the continental shelf near the shelf break (core TC8, $-126 \mathrm{~m}$ and core TC7, $-155 \mathrm{~m}$ below present sea-level) and on the continental slope (core TC6 -240 m below present sea-level) were utilized (Bellotti et al., 1994; Di Bella et al., 2013). All boreholes have provided a detailed description (centimetric scale) of the stratigraphy and lithological and textural information. About $50 \%$ of the boreholes also furnished qualitative and quantitative data on macrofaunistic and microfaunistic content. For several inland boreholes and for the gravity cores, in addition to the microfaunistic content, pollen and geochemical data were available (Bellotti et al., 2007, 2009, 2011; Di Rita et al., 2010, 2015; Di Bella et al., 2011, 2013; Di Rita and Magri, 2012; Milli et al., 2013), thus allowing major constraints for the palaeoenvironmental interpretations. More recently, a new $30 \mathrm{~km}$ long, multichannel seismic line has been acquired along the Tiber River, from $4 \mathrm{~km}$ offshore to Rome. The seismic line, calibrated using the well logs of the area, has allowed detection of some structural elements that are high angle normal faults that dip to the south-west. Some of faults cut the TDS boundary and deform the lower portion of the TDS itself, indicating tectonic activity over the last $20 \mathrm{kyr}$ (Bigi et al., 2014).

These data have constituted a robust database for environmental and stratigraphic interpretation. In order to better define the age of the TDS deposits, 87 calibrated radiocarbon datings were used, both new and from previous datasets (see Table 1 with references).

For the construction of correlation panels (Fig. 6) presented in this work 169 boreholes were utilized with their radiocarbon dating (32), the stratigraphy and facies analysis of which was revisited in order to better constrain the environmental interpretation. For the same reason all the stratigraphic descriptions and radiocarbon dating of the boreholes closest to those used for the construction of the correlation pan- 


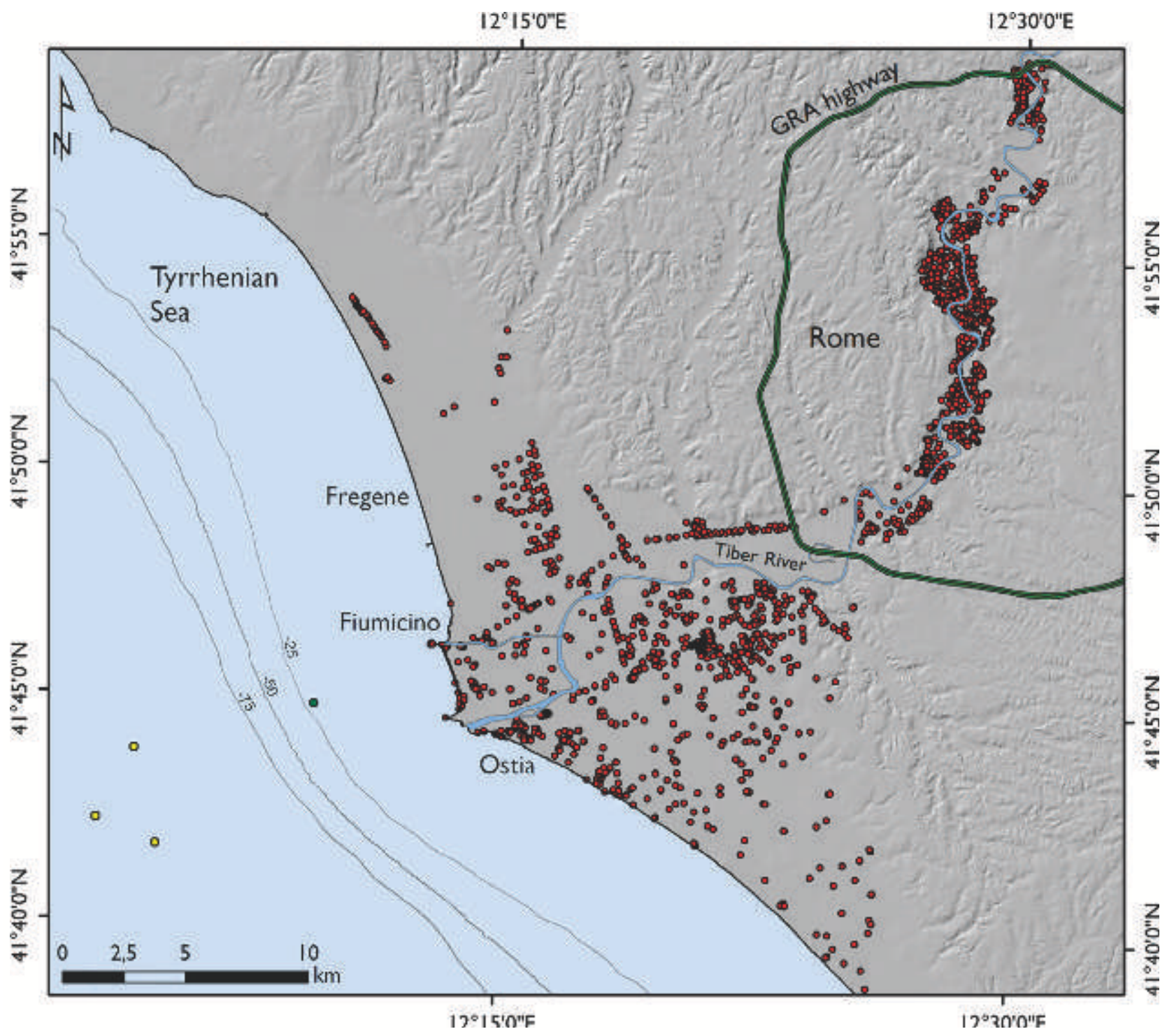

Fig. 5. Investigated area and location of the boreholes (red and green balls) and cores (yellow balls) utilized in the present study and stored in the CNR-IGAG database.

els were used in order to obtain a palaeogeographic framework as reliable as possible.

Because there were no obvious tectonic movements (essentially faults), the normal stratigraphic correlation procedures were used. This approach made it possible to assess the extension of the different geobodies (with the obvious limitations related to the same stratigraphic procedures), and the lateral and vertical stratigraphic relationships between the different lithological units. These procedures enabled the construction of the palaeogeographic schemes, which represent horizon time slices showing in plan the extension and the transition among the coeval depositional systems developing into the TDS. The combination of all these data, thus permitted not only the construction of several correlation panels but also a more detailed description and interpretation of the depositional systems and systems tracts forming the TDS and their stacking patterns. In this work, an improved revision of the previously published correlation panels located below the present Tiber delta plain are presented and new correlation panels are shown, the longest of which, $60 \mathrm{~km}$ long, encompasses the entire TDS from inland to the shelf edge (Fig. 7). 
Table 1. List of radiocarbon dates from cores occurring in the Tiber alluvial and delta plain and on the continental shelf.

\begin{tabular}{|c|c|c|c|c|c|c|c|}
\hline $\begin{array}{l}\text { Sample } \\
\text { identifier }\end{array}$ & Well & $\begin{array}{l}\text { Core- } \\
\text { depth (m) }\end{array}$ & Material & $\begin{array}{l}\text { Conventional } \\
\left({ }^{14} \mathrm{C} \text { age, yr вP }\right)\end{array}$ & $\begin{array}{l}\text { Calibrated } \\
\text { age (cal. вр) }\end{array}$ & $\begin{array}{l}\delta{ }^{13} \mathrm{C}^{(2)}(\% \\
\text { versus SMOW) }\end{array}$ & References \\
\hline Rome-1570 & $\mathrm{C}$ & $-9 \cdot 40$ & Sand with peat & $975 \pm 50$ & $945-795$ & $-27 \cdot 5$ & Bellotti et al. (2007) \\
\hline LTL-461 a & 9 & $-3 \cdot 50$ & Peaty sand & $1140 \pm 40$ & $1165-970$ & $-27 \cdot 1$ & Di Bella et al. (2011) \\
\hline Rome-2137 & PL & $-10 \cdot 00$ & Organic sand & $1445 \pm 50$ & $1390-1290$ & $-27 \cdot 0$ & Milli et al. (2013) \\
\hline LTL-463 a & 12 & $-4 \cdot 50$ & Sand with vegetal remains & $1885 \pm 50$ & $1880-1735$ & $-24 \cdot 5$ & Di Bella et al. (2011) \\
\hline DSH3171 & ATST1 & $-4 \cdot 40$ & Terrestrial gastropod & $2050 \pm 35$ & $2120-1925$ & $-8 \cdot 0$ & Mancini et al. (2013) \\
\hline LTL-467 a & 5 & $-7 \cdot 75$ & Vegetal remains & $2165 \pm 50$ & $2305-2065$ & $-19 \cdot 8$ & Di Bella et al. (2011) \\
\hline DSH5736 & FILAS1 & $-5 \cdot 80$ & Terrestrial gastropod & $2192 \pm 40$ & $2330-2113$ & $-3 \cdot 0$ & This work \\
\hline LTL-460 a & 4 & $-3 \cdot 20$ & Marine mollusc & $2385 \pm 35$ & $2465-2345$ & $+1 \cdot 4$ & Bellotti et al. (2007) \\
\hline DSH3190 & ATST2 & $-6 \cdot 30$ & Wood fragment & $2469 \pm 35$ & $2623-2430$ & $-45 \cdot 0$ & Mancini et al. (2013) \\
\hline LTL-469 a & 7 & $-11 \cdot 00$ & Marine mollusc & $2485 \pm 40$ & $2710-2470$ & $-5 \cdot 6$ & Bellotti et al. (2007) \\
\hline Rome-2069 & S5 & -3.00 & Peat & $2555 \pm 50$ & $2760-2490$ & $-25 \cdot 0$ & Bellotti et al. (2011) \\
\hline Rome-1568 & A & $-3 \cdot 20$ & Organic sand & $2665 \pm 60$ & $2845-2745$ & $-25 \cdot 4$ & Bellotti et al. (2007) \\
\hline Rome-2066 & S3 & $-2 \cdot 00$ & Peat & $2720 \pm 50$ & $2860-2770$ & $-26 \cdot 0$ & Bellotti et al. (2011) \\
\hline LTL-465 а & 12 & $-6 \cdot 50$ & Marine mollusc & $2840 \pm 35$ & $2990-2875$ & +0.4 & Di Bella et al. (2011) \\
\hline LTL-465 а 2 & 12 & $-6 \cdot 50$ & Marine mollusc & $2870 \pm 50$ & $3075-2895$ & $-3 \cdot 1$ & Bellotti et al. (2007) \\
\hline LTL-462 a & 3 & $-4 \cdot 40$ & Sand with peat & $2935 \pm 45$ & $3205-3000$ & $-27 \cdot 5$ & Bellotti et al. (2007) \\
\hline Rome-2068 & S4 & $-1 \cdot 10$ & Peat debris & $3040 \pm 55$ & $3340-3160$ & $-23 \cdot 1$ & Bellotti et al. (2011) \\
\hline LTL7004A & TC835 & $-0 \cdot 90$ & Benthic foraminifera & $3423 \pm 45$ & $3343-3173$ & $+0 \cdot 9$ & Di Bella et al. (2013) \\
\hline LTL-466 a & $2 \mathrm{D}$ & $-7 \cdot 50$ & Peaty sand & $3255 \pm 35$ & $3550-3405$ & $-24 \cdot 3$ & Bellotti et al. (2007) \\
\hline Rome-2071 & S4 & $-1 \cdot 10$ & Peat debris & $3170 \pm 100$ & $3550-3210$ & $-23 \cdot 7$ & Bellotti et al. (2011) \\
\hline Rome-1569 & A & $-8 \cdot 70$ & Peaty silt sand & $3410 \pm 60$ & $3810-3570$ & $-28 \cdot 3$ & Bellotti et al. (2007) \\
\hline Rome-2070 & S5 & $-4 \cdot 20$ & Peat & $3375 \pm 55$ & $3690-3480$ & $-23 \cdot 4$ & Bellotti et al. (2011) \\
\hline Rome-2067 & S3 & $-3 \cdot 10$ & Peat & $3465 \pm 55$ & $3830-3640$ & $-24 \cdot 8$ & Bellotti et al. (2011) \\
\hline LTL4271A & S1 & $-1 \cdot 60$ & Bone fragment & $3520 \pm 40$ & $3840-3700$ & $-21 \cdot 7$ & Bellotti et al. (2011) \\
\hline LTL-470 a & 6 & $-16 \cdot 50$ & Vegetal remains & $3920 \pm 60$ & $4420-4255$ & $-27 \cdot 1$ & Di Bella et al. (2011) \\
\hline LTL4902A & TC824 & $-1 \cdot 80$ & Benthic foraminifera & $5147 \pm 45$ & $5568-5407$ & $-3 \cdot 9$ & Di Bella et al. (2013) \\
\hline $\mathrm{R}-887 \mathrm{~A} / \alpha$ & 150 & -4.00 & Wood & $4640 \pm 80$ & $5574-5090$ & $-29 \cdot 0$ & Belluomini et al. (1986) \\
\hline R-1198 $\alpha$ & 150 & -3.00 & Peaty clay & $4710 \pm 50$ & $5575-5325$ & $-30 \cdot 1$ & Belluomini et al. (1986) \\
\hline R-1198 & 150 & -3.00 & Peaty clay & $4750 \pm 60$ & $5585-5330$ & $-30 \cdot 2$ & Belluomini et al. (1986) \\
\hline R-887 & 150 & $-4 \cdot 00$ & Organic clay & $4760 \pm 60$ & $5585-5335$ & $-28 \cdot 4$ & Belluomini et al. (1986) \\
\hline R-1345 & 179 & $-7 \cdot 80$ & Peat & $5140 \pm 60$ & $5985-5755$ & $-28 \cdot 6$ & Belluomini et al. (1986) \\
\hline Rome-1716 & 1 & -4.90 & Wood fragments & $5190 \pm 45$ & $5990-5919$ & $-2 \cdot 3$ & Bellotti et al. (2007) \\
\hline R-1623 & 151 & $-4 \cdot 00$ & Wood & $5250 \pm 50$ & $6170-5930$ & $-27 \cdot 1$ & Belluomini et al. (1986) \\
\hline LTL-471 a & 4 & $-17 \cdot 50$ & Marine mollusc & $5565 \pm 110$ & $6484-6205$ & $-2 \cdot 3$ & Di Bella et al. (2011) \\
\hline DSH5722 & FILAS1 & $-19 \cdot 60$ & Peat & $5821 \pm 23$ & $6738-6640$ & $-22 \cdot 0$ & This work \\
\hline LTL-471 a2 & 4 & $-17 \cdot 50$ & Marine mollusc & $6070 \pm 40$ & $6985-6805$ & $-5 \cdot 9$ & Bellotti et al. (2007) \\
\hline DSH5721 & FILAS1 & $-19 \cdot 20$ & Peat & $6051 \pm 41$ & $7008-6786$ & $-3 \cdot 0$ & This work \\
\hline LTL-468 a & 1 & $-11 \cdot 00$ & Brackish mollusc & $6150 \pm 55$ & $7475-7325$ & $-2 \cdot 0$ & Bellotti et al. (2007) \\
\hline DSH3214 & ATST1 & $-21 \cdot 50$ & Peat & $6812 \pm 40$ & $7705-7581$ & $-29 \cdot 0$ & Mancini et al. (2013) \\
\hline Rome-1616 & $\mathrm{D}$ & $-7 \cdot 80$ & Organic silt & $6935 \pm 70$ & $7825-7675$ & $-26 \cdot 8$ & Bellotti et al. (2007) \\
\hline DSH3189 & ATST1 & $-27 \cdot 00$ & Peat & $7184 \pm 68$ & $8170-7927$ & $-55 \cdot 0$ & Mancini et al. (2013) \\
\hline DSH5723 & FILAS1 & $-24 \cdot 70$ & Organic clay & $7304 \pm 33$ & $8178-8029$ & $-24 \cdot 0$ & This work \\
\hline LTL-472 a & 10 & $-22 \cdot 20$ & Marine mollusc & $7485 \pm 40$ & $8350-8210$ & $-4 \cdot 2$ & Bellotti et al. (2007) \\
\hline $\mathrm{R}-888 \mathrm{~A} / \alpha$ & 150 & $-9 \cdot 20$ & Wood & $7660 \pm 80$ & $8540-8385$ & $-24 \cdot 7$ & Belluomini et al. (1986) \\
\hline
\end{tabular}


Table 1. (continued)

\begin{tabular}{|c|c|c|c|c|c|c|c|}
\hline $\begin{array}{l}\text { Sample } \\
\text { identifier }\end{array}$ & Well & $\begin{array}{l}\text { Core- } \\
\text { depth (m) }\end{array}$ & Material & $\begin{array}{l}\text { Conventional } \\
\left({ }^{14} \mathrm{C} \text { age, yr } \mathrm{BP}\right)\end{array}$ & $\begin{array}{l}\text { Calibrated } \\
\text { age (cal. вр) }\end{array}$ & $\begin{array}{l}\delta{ }^{13} \mathrm{C}^{(2)}(\%, \\
\text { versus SMOW) }\end{array}$ & References \\
\hline $\mathrm{R}-889 \mathrm{~A} / \alpha$ & 150 & $-9 \cdot 30$ & Wood & $7670 \pm 70$ & $8535-8390$ & $-26 \cdot 4$ & Belluomini et al. (1986) \\
\hline R-888 & 150 & $-9 \cdot 20$ & Organic clay & $7730 \pm 80$ & $8585-8420$ & $-28 \cdot 1$ & Belluomini et al. (1986) \\
\hline R-889 & 150 & $-9 \cdot 35$ & Organic clay & $7770 \pm 60$ & $8590-8455$ & $-26 \cdot 8$ & Belluomini et al. (1986) \\
\hline DSH5735 & FILAS1 & -23.00 & Freshwater gastropod & $7799 \pm 30$ & $8638-8537$ & $+3 \cdot 0$ & This work \\
\hline DSH5724 & FILAS1 & $-39 \cdot 70$ & Wood fragment & $8717 \pm 38$ & $8797-8551$ & $-38 \cdot 0$ & This work \\
\hline R-890 & 150 & $-9 \cdot 50$ & Organic clay & $7930 \pm 70$ & $8990-8605$ & $-28 \cdot 0$ & Belluomini et al. (1986) \\
\hline Rome-1718 & 1 & $-27 \cdot 00$ & Wood fragments & $8490 \pm 70$ & $9535-9435$ & $-28 \cdot 1$ & Bellotti et al. (2007) \\
\hline R-1347 & 179 & $-30 \cdot 90$ & Peat & $8690 \pm 60$ & $9715-9550$ & $-30 \cdot 5$ & Belluomini et al. (1986) \\
\hline R-1346 & 179 & $-30 \cdot 10$ & Peat & $8750 \pm 50$ & $9890-9605$ & $-30 \cdot 7$ & Belluomini et al. (1986) \\
\hline DSH5725 & FILAS1 & -41.60 & Wood fragment & $8997 \pm 34$ & $10239-10150$ & $-20 \cdot 0$ & This work \\
\hline DSH5726 & FILAS1 & $-44 \cdot 25$ & Charcoal & $9090 \pm 40$ & $10299-10188$ & $-15 \cdot 0$ & This work \\
\hline DSH5727 & FILAS1 & $-45 \cdot 40$ & Wood fragment & $9176 \pm 36$ & $10428-10243$ & $-26 \cdot 0$ & This work \\
\hline LTL-474 a & 1 & $-47 \cdot 60$ & Vegetal remains & $9220 \pm 80$ & $10480-10245$ & $-29 \cdot 5$ & Bellotti et al. (2007) \\
\hline DSH3187 & ATST1 & $-41 \cdot 40$ & Peat & $9269 \pm 60$ & $10641-10256$ & $-49 \cdot 0$ & Mancini et al. (2013) \\
\hline Rome-2143 & PL94 & $-37 \cdot 60$ & Peat & $9345 \pm 75$ & $10690-10420$ & $-23 \cdot 6$ & Milli et al. (2013) \\
\hline R-1625 & 151 & $-31 \cdot 00$ & Wood & $9500 \pm 90$ & $11065-10595$ & $-26 \cdot 2$ & Belluomini et al. (1986) \\
\hline R-1200 & 152 & $-31 \cdot 00$ & Organic clay & $9580 \pm 60$ & $11090-10755$ & $-29 \cdot 5$ & Belluomini et al. (1986) \\
\hline $\mathrm{R}-1200 \mathrm{~A} / \alpha$ & 152 & -31.00 & Wood & $9750 \pm 80$ & $11230-10890$ & $-24 \cdot 2$ & Belluomini et al. (1986) \\
\hline LTL-475 а & 1 & $-56 \cdot 00$ & Vegetal remains & $9965 \pm 55$ & $11545-11235$ & $-29 \cdot 8$ & Bellotti et al. (2007) \\
\hline Rome-2142 & PL105 & $-38 \cdot 70$ & Peat & $9955 \pm 80$ & $11560-11220$ & $-24 \cdot 7$ & Milli et al. (2013) \\
\hline Rome-1724 & 3 & -33.50 & Organic clayey silt & $10160 \pm 75$ & $12070-11445$ & $-29 \cdot 0$ & Bellotti et al. (2007) \\
\hline R-1199 & 152 & $-31 \cdot 00$ & Organic clay & $10180 \pm 80$ & $12100-11575$ & $-28 \cdot 5$ & Belluomini et al. (1986) \\
\hline DSH3191 & ATST2 & $-50 \cdot 20$ & Peat & $10340 \pm 42$ & $12392-12033$ & $-25 \cdot 0$ & Mancini et al. (2013) \\
\hline DSH5728 & FILAS1 & -48.90 & Charcoal & $10470 \pm 38$ & $12557-12374$ & $-37 \cdot 2$ & This work \\
\hline Rome-1720 & 3 & $-30 \cdot 50$ & Organic clayey silt & $10340 \pm 80$ & $12595-11955$ & $-24 \cdot 8$ & Bellotti et al. (2007) \\
\hline Rome-2138 & PL87 & $-36 \cdot 90$ & Peaty clay & $10390 \pm 80$ & $12650-11950$ & -24.9 & Milli et al. (2013) \\
\hline R-2639 & S3f & $-66 \cdot 00$ & & $10735 \pm 75$ & $12935-12645$ & $-27 \cdot 2$ & Bellotti et al. (2007) \\
\hline Rome-2144 & PL128 & $-43 \cdot 50$ & & $10835 \pm 85$ & $13010-12660$ & $-23 \cdot 3$ & Milli et al. (2013) \\
\hline Rome-2139 & PL138 & $-44 \cdot 40$ & & $10960 \pm 80$ & $13140-12900$ & $-23 \cdot 7$ & Milli et al. (2013) \\
\hline Rome-1723 & 5 & $-40 \cdot 20$ & & $11010 \pm 80$ & $13140-12950$ & $-28 \cdot 5$ & Bellotti et al. (2007) \\
\hline Rome-2140 & PL136/138 & $-44 \cdot 30 /-44 \cdot 50$ & Peaty clay & $11010 \pm 85$ & $13150-12940$ & $-25 \cdot 8$ & Milli et al. (2013) \\
\hline Rome-1722 & 1 & -54.50 & & $11410 \pm 75$ & $13450-13190$ & $-27 \cdot 0$ & Bellotti et al. (2007) \\
\hline LTL-473 a2 & $2 \mathrm{C}$ & $-23 \cdot 00$ & & $12130 \pm 65$ & $14970-13840$ & $-11 \cdot 6$ & Bellotti et al. (2007) \\
\hline $\mathrm{R}-2639$ bis & S3f & $-68 \cdot 50$ & & $12400 \pm 80$ & $15030-14135$ & $-26 \cdot 1$ & Bellotti et al. (2007) \\
\hline Rome-2141 & PL120 & $-40 \cdot 80$ & Organic clay & $12445 \pm 90$ & $15250-14150$ & $-25 \cdot 8$ & Milli et al. (2013) \\
\hline LTL-473 a & $2 \mathrm{C}$ & $-23 \cdot 00$ & & $12640 \pm 90$ & $15515-14345$ & $-7 \cdot 4$ & Bellotti et al. (2007) \\
\hline LTL4900A & TC8_18 & $-2 \cdot 40$ & Marine mollusc & $27824 \pm 300$ & $31781-31265$ & $-3 \cdot 5$ & Di Bella et al. (2013) \\
\hline LTL4899A & TC8 4 & $-3 \cdot 80$ & Marine mollusc & $33389 \pm 350$ & $38028-36861$ & $-4 \cdot 0$ & Di Bella et al. (2013) \\
\hline LTL4901A & TC8 1 & $-4 \cdot 10$ & Benthic foraminifera & $34638 \pm 300$ & $39501-38706$ & $-8 \cdot 0$ & Di Bella et al. (2013) \\
\hline R-891 & 150 & $-25 \cdot 00$ & & $>41000$ & >41000 no cal. & $-30 \cdot 3$ & Belluomini et al. (1986) \\
\hline Rome-1571 & $\mathrm{C}$ & $-35 \cdot 50$ & & $>45000$ & $>45000$ no cal. & $-26 \cdot 4$ & Bellotti et al. (2007) \\
\hline Rome-1618 & $\mathrm{E}$ & $-12 \cdot 00$ & & $>44000$ & $>44000$ no cal. & $-28 \cdot 5$ & Bellotti et al. (2007) \\
\hline Rome-1617 & $\mathrm{D}$ & -11.00 & & $>45000$ & $>45000$ no cal. & $-28 \cdot 2$ & Bellotti et al. (2007) \\
\hline
\end{tabular}

$7770 \pm 60$

$8750 \pm 50$

$50 \pm 80$

$9965 \pm 55$

$160 \pm 75$

$180 \pm 80$

$10340 \pm 80$

$390 \pm 80$

$10835 \pm 85$

$0960 \pm 80$

$11010 \pm 85$

$24 \pm 30$

$33389 \pm 350$

$>41000$

$>45000$ 


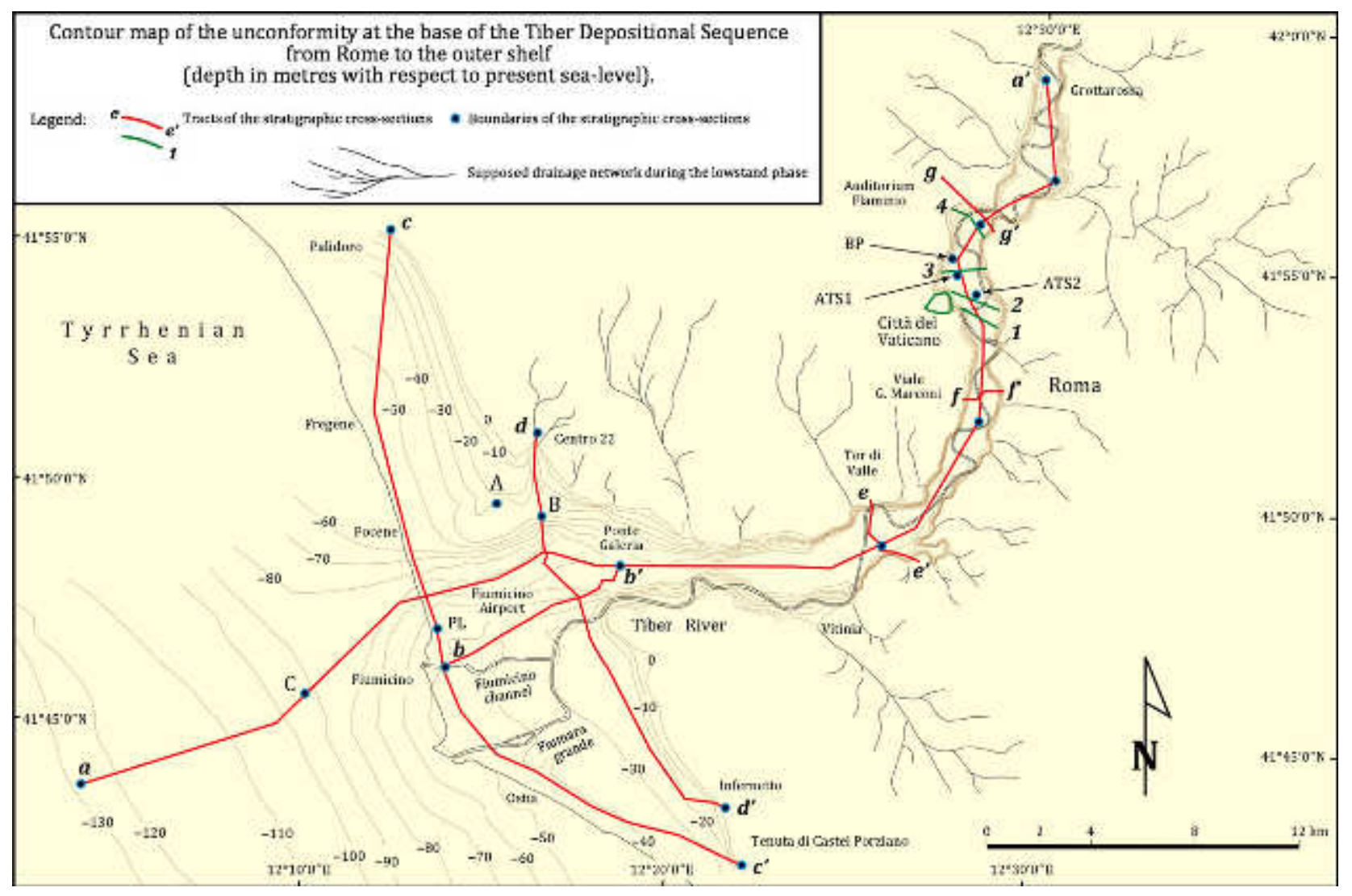

Fig. 6. Contour map (in metres) of the Tiber depositional sequence boundary from Rome to the outer shelf. Red lines indicate the track of stratigraphic cross-sections of Fig. 7. Green lines indicate the track of stratigraphic cross-sections of Figs 18 to 20. For the stratigraphy of the TC8 core ( $a$ on the map) and of the boreholes A, B, C, PL, ATS1, ATS2 and BP see Figs 9, 10, 13, 14, 15, 16 and 17, respectively.

\section{THE TIBER DEPOSITIONAL SEQUENCE}

The TDS represents one of the most complete high-frequency sequences in the Mediterranean area, where all the systems tracts are present. Nevertheless, the major thickness of sediments occurs within the inland alluvial valley and below the present delta plain, where a thick transgressive-regressive wedge, formed during the last 14 kyr, is well-preserved (Fig. 7).

The TDS comprises the sedimentary succession that developed during the last glacial-interglacial cycle of post-Tyrrhenian age, and constitutes an incomplete sequence that is still evolving. Its thickness ranges from $<1 \mathrm{~m}$ to 30 to $40 \mathrm{~m}$, reaching approximately $80 \mathrm{~m}$ along the axis of the incised valley. The lower boundary of this sequence is an erosional surface, which is carved into the underlying Lower-Middle Pleistocene deposits, and began to form with the sealevel fall that followed the last highstand phase correlated with the MIS 5.5. The peak of this fall coincides with the last glacial maximum expansion (LGM) and, in particular, with the most negative peak (between $19 \mathrm{ka}$ and $17 \mathrm{ka}$ cal вр) of MIS 2 (see Chappell \& Shackleton, 1986; Martinson et al., 1987; Shackleton, 1995; Lambeck et al., 2002; Peltier \& Fairbanks, 2006). Irrespective of the beginning of the LGM, which is still debated, the end of this period is unanimously placed at $19 \mathrm{ka}$. Starting from this date, in fact, there was an initial melting of ice and a concomitant slow rise in sea-level that lasted up to ca $14 \mathrm{ka}$. Based on these interpretations, the present authors correlate the end of the eustatic sealevel fall with the onset of the LGM. This period

Fig. 7. Stratigraphic cross-sections showing the depositional architecture of the Tiber Sequence. For the tracks of cross-sections, see Fig. 6. 


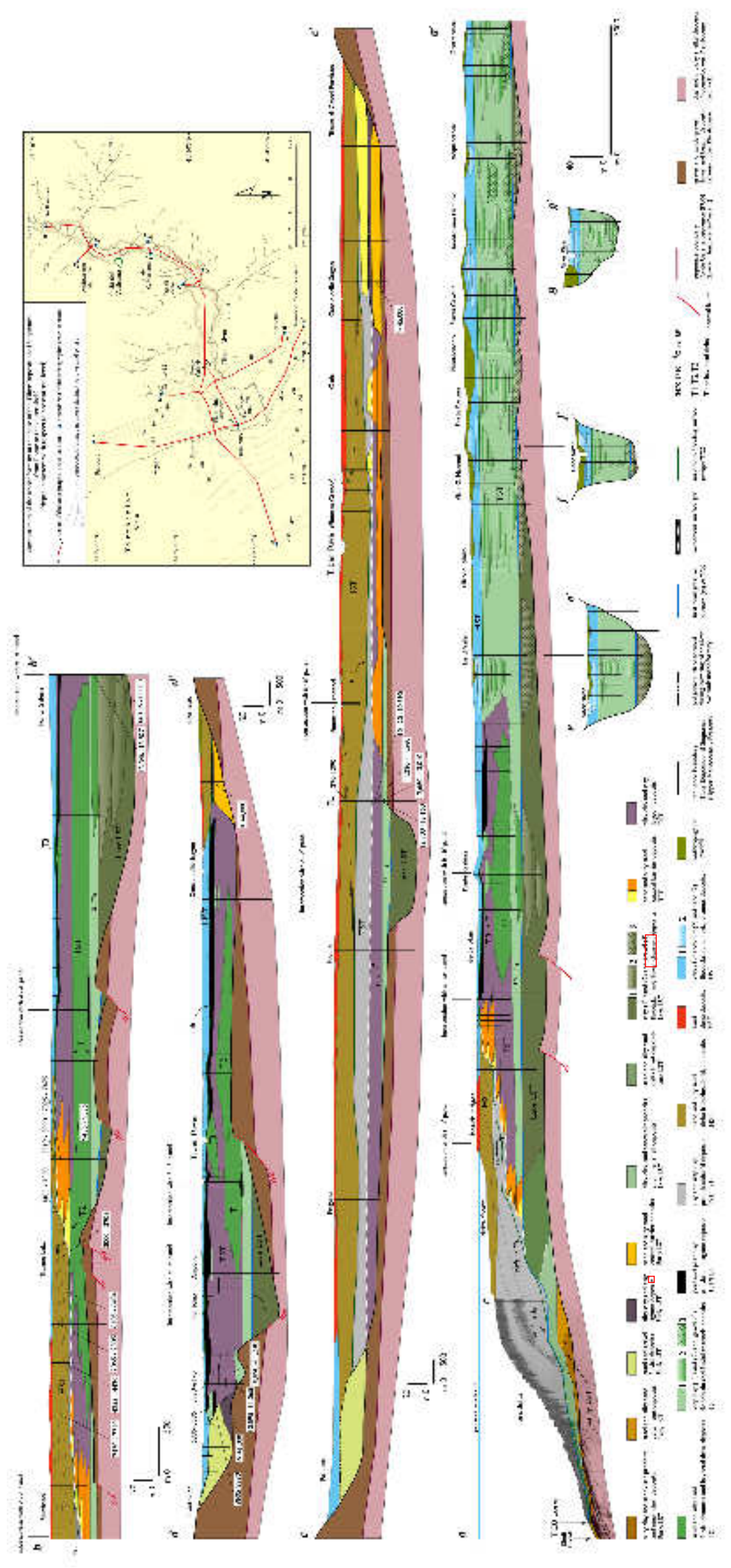


corresponds, from a sequence stratigraphy point of view, to the deposition of the Early Lowstand Systems Tract (ELST). The duration of the LGM should coincide with a eustatic stillstand phase and this, together with the subsequent initial eustatic rise, is considered to correspond to the period during which the LLST developed. The previous assumptions constitute the basis for the description and interpretation of the TDS systems tract in the paragraphs below.

\section{Lowstand Systems Tract}

In the Tiber area, as in other sectors of the Mediterranean Sea, several data suggest that the lowstand deposition took place between $120 \mathrm{ka}$ and $14 \mathrm{ka}$ cal вр (i.e. from the beginning of substage $5 \mathrm{~d}$ to the final phase of stage 2) (see Coutellier \& Stanley, 1987; Hernández-Molina et al., 1994; Stanley \& Warne, 1994; Amorosi \& Milli, 2001; Boyer et al., 2005; Labaune et al., 2005). During this period, falling, stillstand and the slow initial rise of relative sea-level occurred. This give rise to the formation of the Tiber-incised valley and to deposition of the sediments constituting the early and the late lowstand systems tracts, respectively.

\section{The Tiber depositional sequence boundary}

The surface underlying the forced regressive deposits is considered to represent the master sequence boundary (sensu Posamentier \& Allen, 1999) of the TDS ('TDS boundary' hereafter). This surface began to form as a result of fluvial incision during the overall relative sea-level fall, a fall that was episodic and punctuated by multiple higher frequency sea-level cycles. These cycles produced a series of high-frequency unconformities bounding small-scale depositional sequences of lower rank than the TDS (Fig. 8). These units are occasionally preserved within the inland Tiber-incised valley, the base and walls of which coincide with the TDS boundary; they are partially preserved below the present delta plain where they formed down-stepping terraced deposits bounded by an erosional surface (low rank sequence boundaries) merging into the TDS boundary (Fig. 7). Seaward, the TDS boundary has been identified on the continental shelf through high-resolution seismic profiles (Bellotti et al., 1994; Chiocci \& Milli, 1995). It shows the characteristics of an erosional unconformity cutting the Pleistocene clinoforms that constitute the outbuilding structure of the continental margin (Fig. 7). In the inner shelf below the present delta

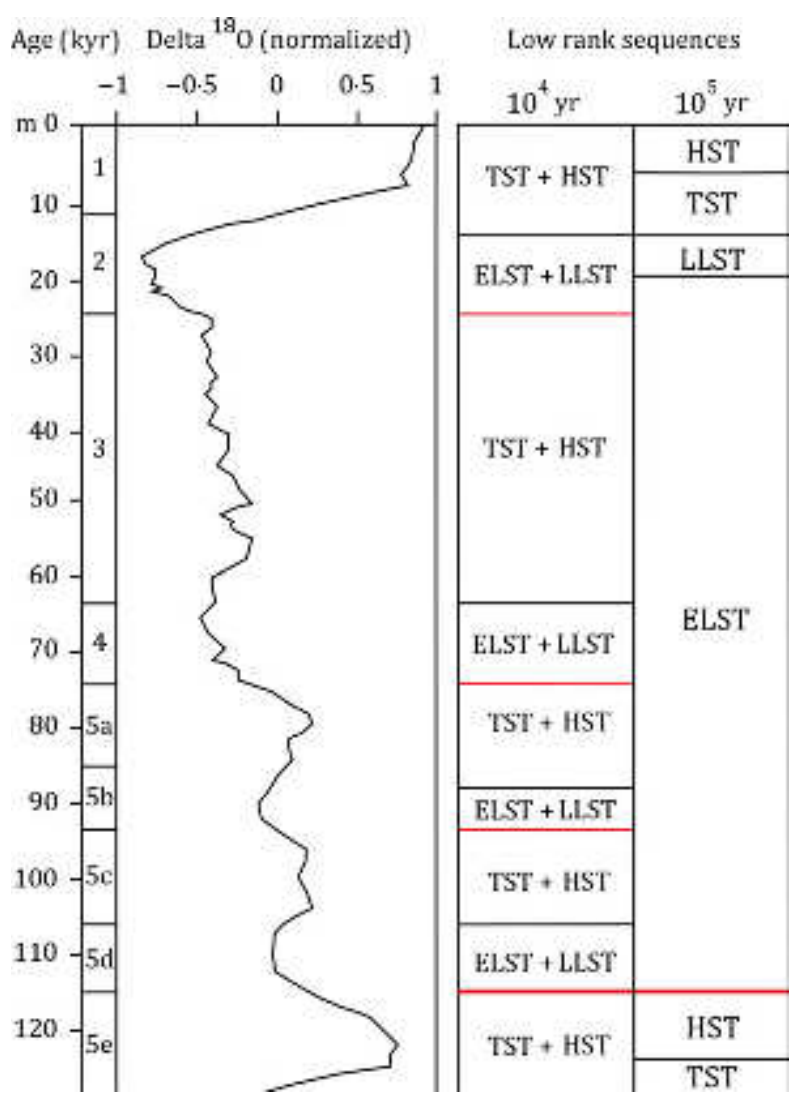

Fig. 8. Correlation between the oxygen isotope curve (Martinson et al., 1987) and the sequence-stratigraphic interpretation of the study succession. The low rank sequence with a duration of $10^{5} \mathrm{yr}$ coincides with the Tiber depositional sequence (TDS). The Late Pleistocene sequences of a duration of $10^{4} \mathrm{yr}$ are sporadically preserved within the Roman basin. Numbers refer to oxygen isotope stage and substages. The thicker red line indicates the TDS sequence boundary. The other thinner red lines indicate high-frequency unconformities bounding small-scale depositional sequences of lower rank than the TDS. ELST, Early Lowstand Systems Tract; LLST, Late Lowstand Systems Tract; TST, Transgressive Systems Tract; HST, Highstand Systems Tract.

front, lack of a good seismic pulse penetration made it difficult to reconstruct the TDS boundary. Nonetheless, the refinement of previous information and new data presented in this paper allowed reconstruction of the TDS boundary in this sector, as well as the positioning of the early lowstand Tiber delta (Fig. 7). In the middle and outer shelf sectors, the TDS boundary still maintains the character of an erosional surface that has been interpreted to form by erosion through wave scour during the forced regression phase (Di Bella et al., 2013). The TDS boundary corresponds here with the 'regressive surface of mar- 
ine erosion' of Plint (1988) and Catuneanu et al. (2009, 2011). Evidence of the passage to a true correlative conformity occurs only on the continental slope, where the TDS boundary loses its erosional character and becomes a conformable surface overlain by LST deposits (Chiocci \& Milli, 1995).

\section{Early Lowstand Systems Tract}

These deposits (between 120 ka and 26 ka вр) are difficult to detect in the inland incised valley, while they occur below the present delta plain and on the shelf. In the former area, they consist of fluvial, lagoonal and beach deposits. Based on four radiocarbon data from lagoonal peaty muds indicating an age older than $40 \mathrm{ka} \mathrm{BP}$, and on the geological, pedological and archaeological data from fluvial deposits (Arnoldus-Huyzendveld et al., 1993; Bellotti et al., 2007), an age of at least $90 \mathrm{ka}$ BP is estimated for the early lowstand deposits occurring below the present delta plain (Fig. 7). Therefore, these deposits are considered herein as the first downstepping forced regressive deposits formed after the post-125 ka вP sealevel fall. In particular, they are attributed to the transgressive/highstand systems tracts related to one of the low rank depositional sequences constituting the early lowstand of TDS (probably substage 5c). Fluvial deposits are characterized by different lithofacies, ranging from sand and gravel to mud and travertine. Such deposits are organized in fining-upward facies sequences that are interpreted as the filling of low-sinuosity channels of a braided fluvial depositional system (Fig. 9). In particular, sands and gravels should have constituted bar bodies that filled the channels, while the mud, also due to the presence of Pulmonata gastropods, is interpreted as a floodplain deposit. As a whole, these fluvial deposits form a sedimentary body with a tabular geometry that extends over 3 to $5 \mathrm{~km}$, with a thickness ranging between $10 \mathrm{~m}$ and $30 \mathrm{~m}$ (Bellotti et al., 1989, 1995). Beach deposits consist of gravels and sandy gravels forming coarsening-upward facies sequences. When preserved, such sequences show an overall passage from lower and upper shoreface to foreshore, and finally a backshore facies (see Table 2 for faunal assemblages). Lagoonal facies consist of organic-rich mud deposits with frequent intercalations of thin sandy layers often associated with shell debris.

Seaward, early lowstand deposits have been recognized and dated in core TC8 (Fig. 10). Here an increased sedimentation rate from 18.0 to $23.6 \mathrm{~cm} \mathrm{ka}^{-1}$ has been calculated between $39.0 \mathrm{ka}$ and $c a$ 30.0 ka BP (Di Bella et al., 2013). These data are consistent with the depositional context, i.e. an increased sediment supply from an incising river during forced regression. Micropalaeontological data indicate a domi-

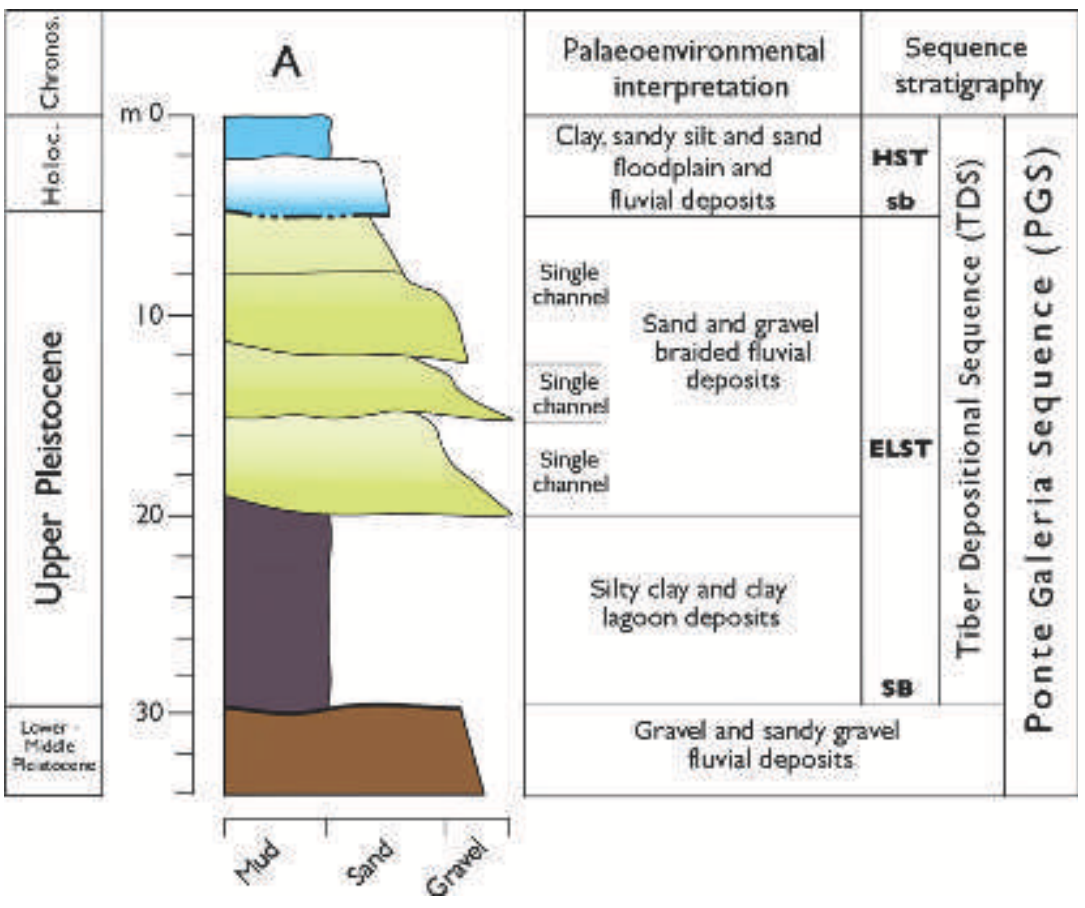

Fig. 9. Stratigraphic column of the A core showing the main depositional environments forming the early lowstand deposits of the Tiber depositional sequence (TDS) in the northern sector of the investigated area. For location see Fig. 6. The log shows either the boundary of the TDS (SB), or the boundary (sb) of a lower rank sequence formed during the early lowstand phase of the TDS. HST, Highstand Systems Tract; ELST, Early Lowstand Systems Tract. See also Fig. 7. 
(2) Table 2. Main faunal assemblages in the systems tracts of the Tiber depositional sequence (TDS). BF, benthic foraminifera; PF, planktonic foraminifera; N ELST, Early Lowstand Systems Tract; LLST, Late Lowstand Systems Tract; TST, Transgressive Systems Tract; HST, Highstand Systems Tract.

\begin{tabular}{|c|c|c|c|}
\hline Main lithofacies & Fauna & Environment & Systems tract \\
\hline Mud & Pulmonata gastropoda & Floodplain & ELST \\
\hline Gravels and sandy gravel & $\begin{array}{l}\text { BF: Elphidium spp. Lobatula lobatula, Ammonia parkinsoniana, } \\
\text { Asterigerinata mamilla; shell fragments, pulmonata gastropoda }\end{array}$ & $\begin{array}{l}\text { Beach deposits (from back- } \\
\text { shore to foreshore and } \\
\text { upper and lower shoreface) }\end{array}$ & ELST \\
\hline Sandy mud and mud & $\begin{array}{l}\text { PF: Turborotalia quinqueloba, Globigerinita glutinata, } \\
\text { Globorotalia scitula }\end{array}$ & Shelf-transition & ELST \\
\hline Sandy mud & $\begin{array}{l}\text { PF: Globorotalia inflata, Globigerinoides spp., Globorotalia } \\
\text { scitula, Globigerina bulloides }\end{array}$ & Delta front to prodelta slope & LLST \\
\hline Clay and silty mud & Freshwater gastropoda (Planorbis planorbis) & Floodplain & TST \\
\hline $\begin{array}{l}\text { Mud with fine sands } \\
\text { and silty sand, and peaty mud }\end{array}$ & Bittium reticulatum and others gastropods of Hydrobiidae family & Inner lagoon & TST \\
\hline Mud and silty mud & $\begin{array}{l}\text { BF: Ammonia parkinsoniana, A. perlucida, A. beccarii, } \\
\text { Elphidium crispum, E. granosum, Haynesina depressula, } \\
\text { H. germanica } \\
\text { Ostracods: Cyprideis torosa, Loxoconcha stellifera, Aurila } \\
\text { woodwardi, Leptocythere lagunae, Loxoconcha elliptica, } \\
\text { Palmoconcha turbida }\end{array}$ & Central lagoon & TST \\
\hline $\begin{array}{l}\text { Mud with fine sands } \\
\text { and silty sand }\end{array}$ & $\begin{array}{l}\text { BF: Elphidium granosum, E. poeyanum, } \\
\text { E. advenum, Ammonia parkinsoniana, } \\
\text { A. beccarii, A. tepida, Nonionella turgida and miliolids } \\
\text { Ostracods: Leptocythere ramose, L. bacescoi, } \\
\text { L. lagunae, Loxoconcha subrugosa, Proponto } \\
\text { cypris pirifera, Cytherois fisheri, Carino } \\
\text { cythereis antiquata, Semicytherura incongruens }\end{array}$ & Outer lagoon & TST \\
\hline Sand and sandy silt & $\begin{array}{l}\text { BF: Ammonia beccarii, A. perlucida, Elphidium } \\
\text { erispum, E. advenum, Quinqueloculina seminulum }\end{array}$ & $\begin{array}{l}\text { Beach deposits (from fore- } \\
\text { shore to upper and lower } \\
\text { shoreface) }\end{array}$ & TST \\
\hline $\begin{array}{l}\text { Silty clay with very } \\
\text { fine sand layers }\end{array}$ & $\begin{array}{l}\text { BF: Ammonia parkinsoniana, A. beccarii, Elphidium poeyanum } \\
\text { PF: Globigerina bulloides, Globigerinita } \\
\text { glutinata, Globigerinoides ruber, Turborotalia quinqueloba } \\
\text { Ostracods: Palmoconcha turbida, Pontocythere turbida }\end{array}$ & Shelf-transition & TST \\
\hline $\begin{array}{l}\text { Fine to very fine sands } \\
\text { with silty clay levels }\end{array}$ & $\begin{array}{l}\text { BF: Ammonia parkinsoniana, A. beccarii, } \\
\text { Elphidium poeyanum, Triloculina spp., } \\
\text { Adelosina spp. }\end{array}$ & Upper and lower shoreface & HST \\
\hline
\end{tabular}


Table 2. (continued)

\begin{tabular}{|c|c|c|c|}
\hline Main lithofacies & Fauna & Environment & Systems tract \\
\hline & $\begin{array}{l}\text { PF: Globigerina bulloides, Globigerinita glutinata, Globigerinoides } \\
\text { ruber, Turborotalia quinqueloba }\end{array}$ & & \\
\hline Silty clay & $\begin{array}{l}\text { BF: Ammonia parkinsoniana, A. beccarii, A. tepida, } \\
\text { Elphidium poeyanum, E. granosum. Quinqueloculina } \\
\text { seminulum, Q. stelligera, Q. pygmaea } \\
\text { PF: Globigerina bulloides, Globigerinita glutinata, } \\
\text { Globigerinoides ruber, Turborotalia quinqueloba } \\
\text { Ostracods: Palmoconcha turbida, Pontocythere } \\
\text { turbida, Carinocythereis antiquata, Semicytherura incongruens, } \\
\text { Leptocythere ramosa }\end{array}$ & Inner shelf & HST \\
\hline Mud and sandy mud & $\begin{array}{l}\text { BF: Bolivina spp., Cassidulina carinata, Bulimina marginata, } \\
\text { Uvigerina mediterranea, Melonis spp. } \\
\text { PF: Globigerinoides spp., Globorotalia inflata, } \\
\text { G. truncatulinoides, Globigerina bulloides, Turborotalia quinqueloba }\end{array}$ & Outer shelf & HST \\
\hline
\end{tabular}


TC8 core
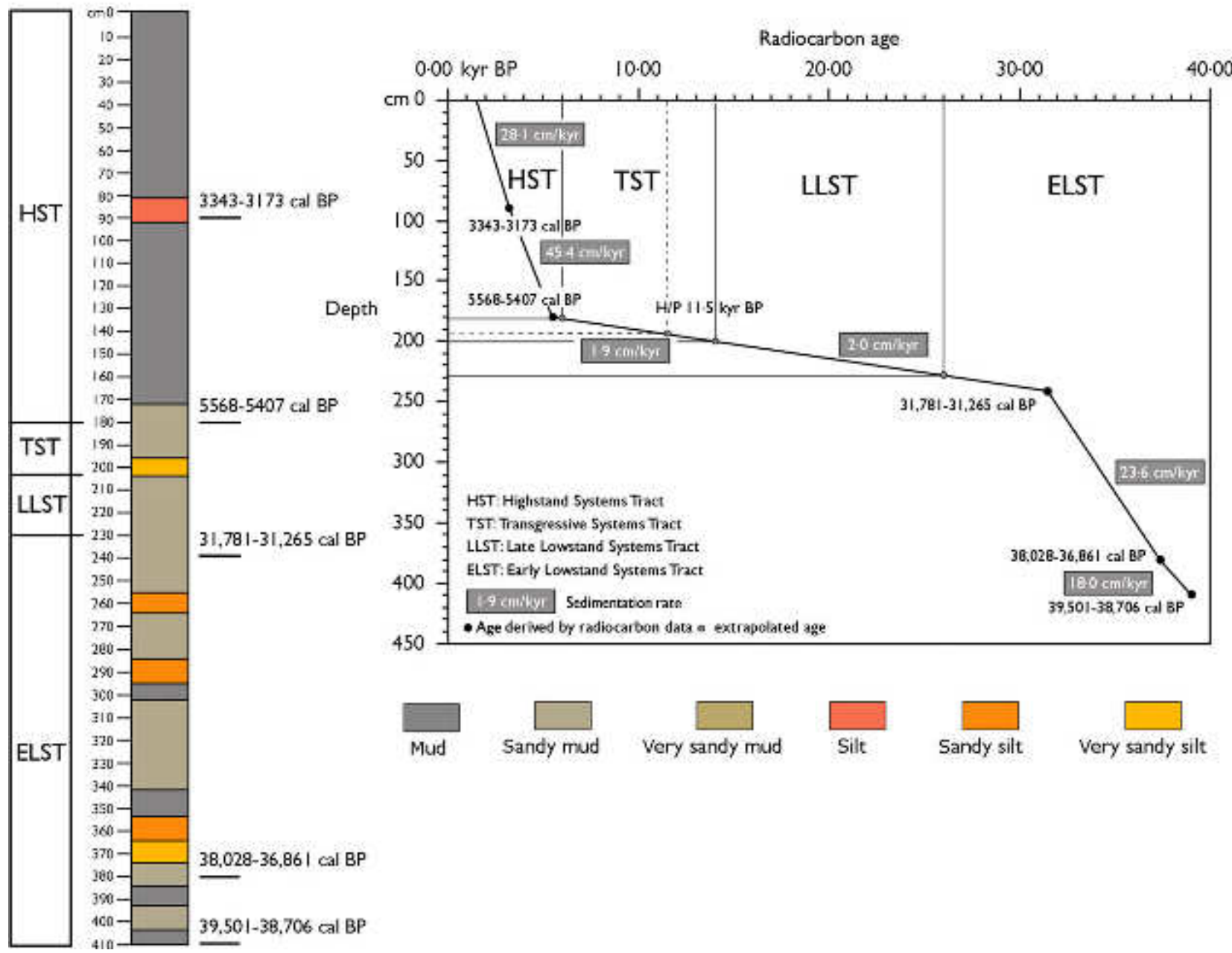

Fig. 10. Sequence-stratigraphic interpretation of core TC8 and age model with estimated sedimentation rate. Data derived from Di Bella et al. (2013).

nance of planktonic cold water species (Table 2). Similarly, a benthonic foraminiferal assemblage is characterized by cold infralittoral species indicating a shallow water environment with low to moderate organic matter content. In particular, the assemblage marks alternations from oligotrophic to more eutrophic conditions, a feature highlighting a fluvial input with nutrient supply (Di Bella et al., 2013). Sediments are mostly constituted of interbedded sandy mud and mud with sharp-based centimetre-sized sandy silt layers with bioclastic material. Together with the microfaunal data they suggest deposition in front of a river mouth (the former Tiber mouth) in shoreface to inner shelf sectors, where a record of hyperpycnal flows and/or storm events occurs. These processes must also be responsible for the formation of the network of gullies occurring on the upper slope (Chiocci \& Normark, 1992; Bellotti et al., 1994), which are inactive today. All of these data suggest a deposition at or slightly below the mean fairweather wave base for these sediments, a depth that is consistent with the supposed position of the Tiber River mouth at the end of the early lowstand phase: $c a 90 \mathrm{~m}$ below the present sealevel (see Depth of the Tiber early lowstand delta section).

\section{Late Lowstand Systems Tract}

The late lowstand deposits (aged between $26 \mathrm{ka}$ and $14 \mathrm{ka} \mathrm{вр)}$ are preserved with different thicknesses from the inland incised valley to the shelf sector. During the late lowstand, the Tiber River flowed in an ENE-WSW direction. Its course, below the present delta plain, was 

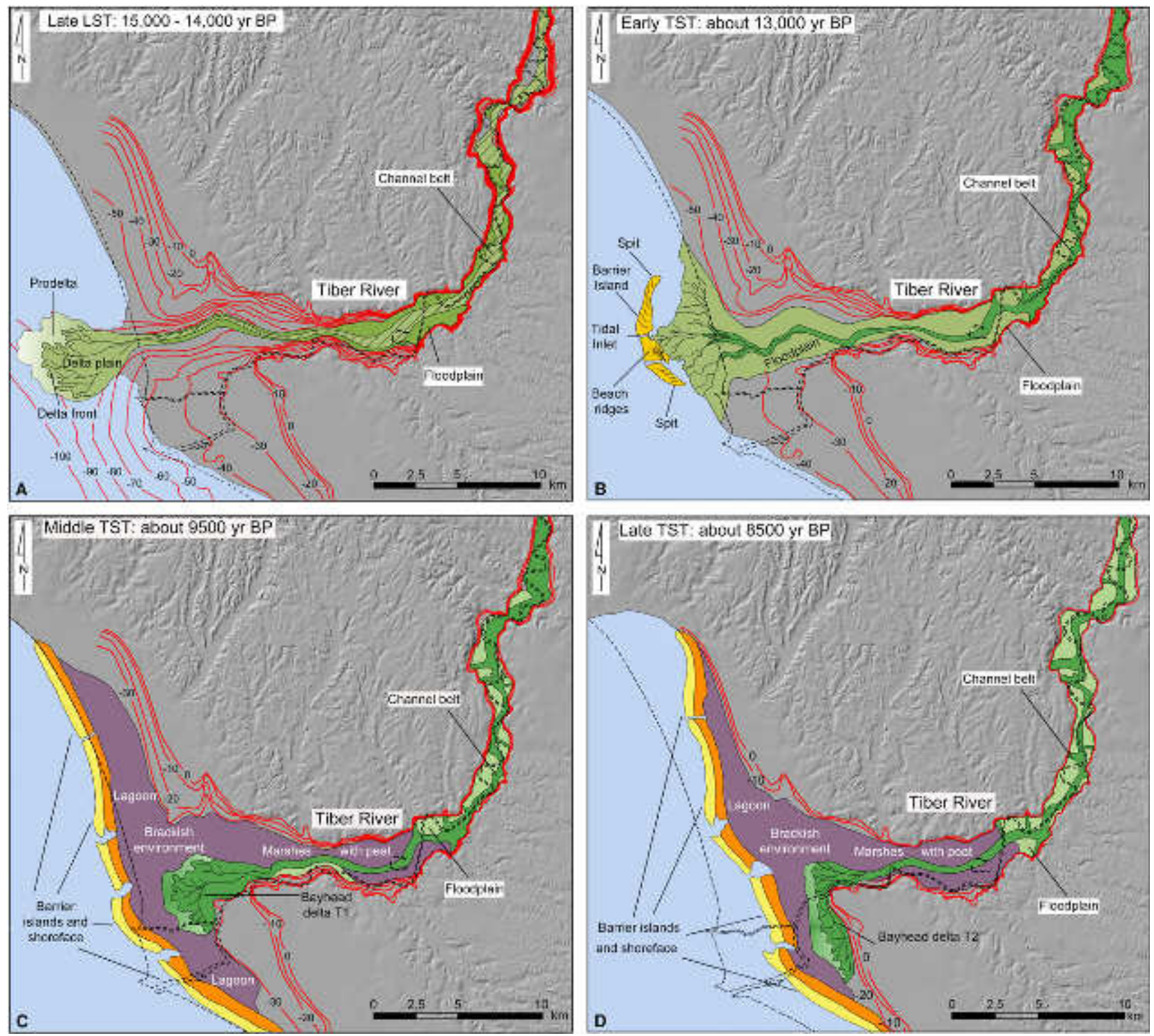

Fig. 11. Palaeogeographical sketches showing evolution of the Tiber River during the last 18000 yr BP. (A) LLST, late lowstand systems tract; (B) to (E) TST, transgressive systems tract; (F) to (H) HST, Highstand Systems Tract. The colours in the figures reflect the different depositional environments characterizing the systems tracts. The red contours (in metres) show the shape of the incised valley and the TDS sequence boundary.

placed 1 to $5 \mathrm{~km}$ north of its present location (Fig. 11A). The best record of the late lowstand deposits is within the Tiber-incised valley, where the thicknesses vary from 5 to $10 \mathrm{~m}$ to $24 \mathrm{~m}$, moving from inland to the coastal plain, respectively (Fig. 7).

In the inland sector, such deposits are composed of fluvial gravels forming an almost continuous tabular body, 6 to $10 \mathrm{~m}$ thick. It grades vertically into a narrower sheet of pebbles and sands, giving rise to amalgamated bars and bedload sheets, which have been attributed to a braided channel belt. Minor floodplain deposits composed of stiff and well-consolidated grey massive clay and silt are present and restricted in the more peripheral parts of the valley infill. Gravels are essentially represented by well-rounded heterometric (although relatively well-sorted) carbonate and chert clasts, less than $10 \mathrm{~cm}$ in diameter (Fig. 12A and B), ellipsoidal or spherical in shape. These clasts are derived from the erosion of the encasing Lower and Middle Pleistocene fluvial and beach deposits cropping out along the margins of the 

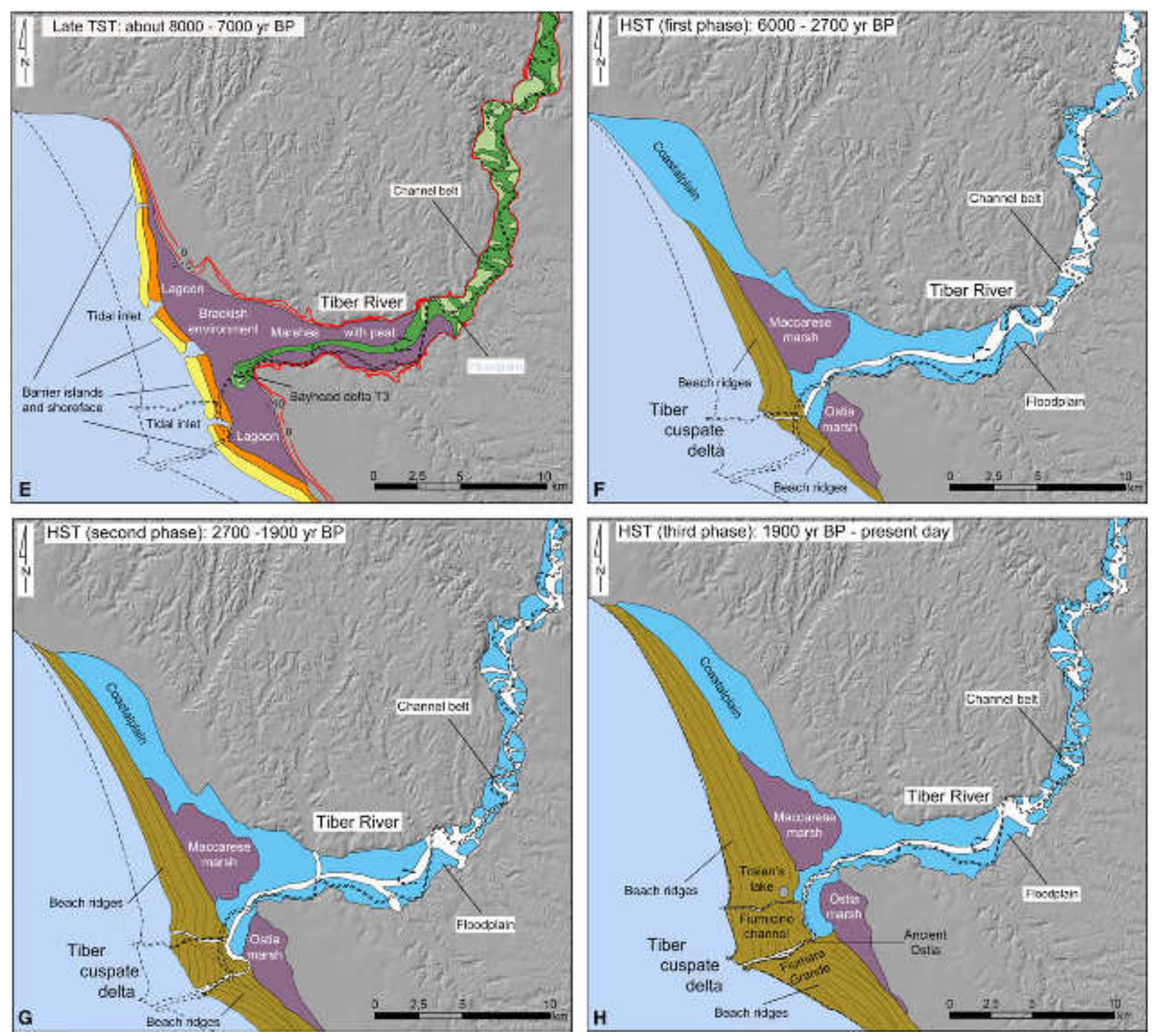

Fig. 11. Continued.

present Tiber delta and alluvial plain. Arenites and rare volcaniclastic material (pumice and tuff) are also present. The sands are rich in quartz, feldspar, muscovite and ferromagnesian minerals. Moving seaward, the thickness of these fluvial deposits increases (Fig. 7), the particle size decreases and sediments are mostly composed of sands and, more rarely, gravelly sands passing laterally and vertically to floodplain muddy deposits with peat layers. Here, a change from a braided to more sinuous channel belt is interpreted to occur, reflecting the increase in new accommodation space and a general decrease in the gradient profile (see also Schumm, 1993; Ethridge et al., 1998; Posamen- tier \& Allen, 1999) at the Tiber mouth. This allowed the development of Tiber deltaic body during the stillstand and slow sea-level rise phases characterizing the late LST. In the present interpretation, this deltaic body was probably located $c a 8$ to $10 \mathrm{~km}$ from its present position. It downlapped directly onto the TDS boundary at a depth between $-80 \mathrm{~m}$ and $-90 \mathrm{~m}$ below the present sea-level. On the basis of the thickness of fluvial deposits within the incised valley, the top of this deltaic body has been estimated at $c a-55 \mathrm{~m}$ below the present sea-level. The reconstructed stratigraphy of the late LST allows the differentiation of a lower and an upper portion, the first being characterized by 

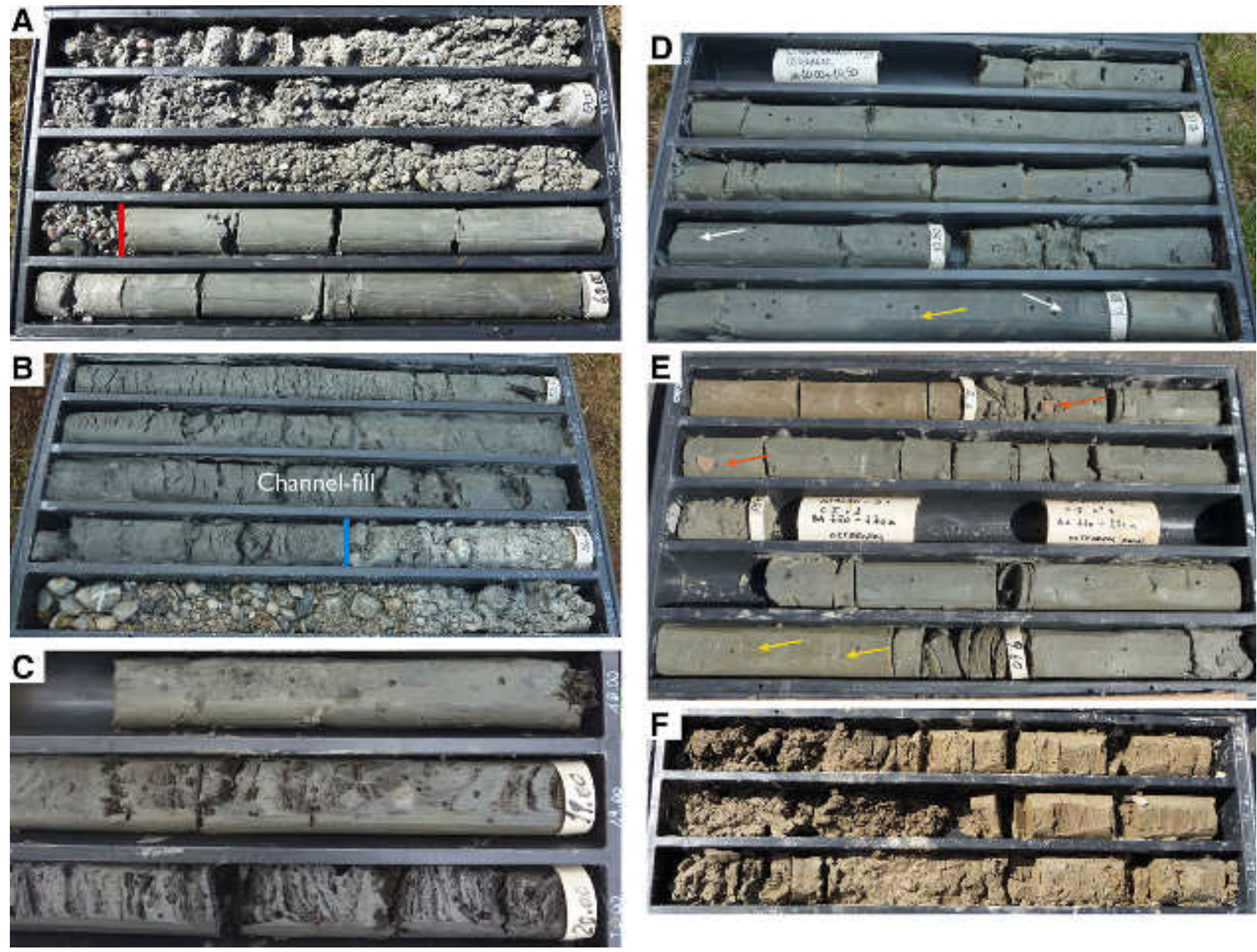

Fig. 12. (A) Late lowstand systems tract (LST) fluvial gravel deposits of the Tiber depositional sequence (TDS) overlying the Pliocene clay and silt clay shelfal deposits. The red line indicates the boundary of the TDS. (B) Late LST fluvial gravel deposits underlying the channel fluvial transgressive deposits of the TDS. The blue line indicates the 'first transgressive surface'. Cores show an example of a typical transgressive channel-fill with mediumcoarse sand at the base, passing upward to fine silty sand. (C) Floodplain reotrophic peat layers with silty deposits of the transgressive systems tract (TST). (D) and (E) Overconsolidated and weakly grey to greenish and pale brown clay and silty clay of floodplain environment formed during the highstand systems tract (HST). Note the presence of centimetric peat layers (white arrow) and carbonate nodules (yellow arrow) as well as the local archaeological remains (orange arrow). (F) Fine-grained laminated sands constituting the filling of a meandering channel.

fluvial and delta progradation, and the second by fluvial and delta aggradation. This change in the depositional trend of late lowstand deposits is related to the increase in sea-level rise rate, although this effect is amplified by the local confinement of the incised valley. Aggradation rates for the more inland and the deltaic sectors of the incised valley fill are estimated at 0.4 to $0.8 \mathrm{~mm} \mathrm{yr}^{-1}$ and $2.0 \mathrm{~mm} \mathrm{yr}^{-1}$, respectively.

The more distal portion of the deltaic deposits is recorded by a thickness of $c a 20 \mathrm{~cm}$ in the offshore TC8 core (Fig. 10). Here, the sediments are essentially constituted of sandy mud with very thin, sandy silt layers. Planktonic foraminifera are dominated by cold taxa similar to those occurring in the early lowstand deposits (Di Bella et al., 2013). The observations derived from these data, together with the calculated sedimentation rate $\left(0.02 \mathrm{~mm} \mathrm{yr}^{-1}\right)$ for this time interval (Fig. 10), suggest a local reduction in the sediment supply that is consistent with the base-level change of the Tiber River, in turn related to the initial sea-level rise. The simultaneous aggradation phase of the fluvial system constitutes the prodrome to the true transgressive phase, and is characterized by an assemblage of sandy fluvial and muddy and peat muddy alluvial deposits with widespread 


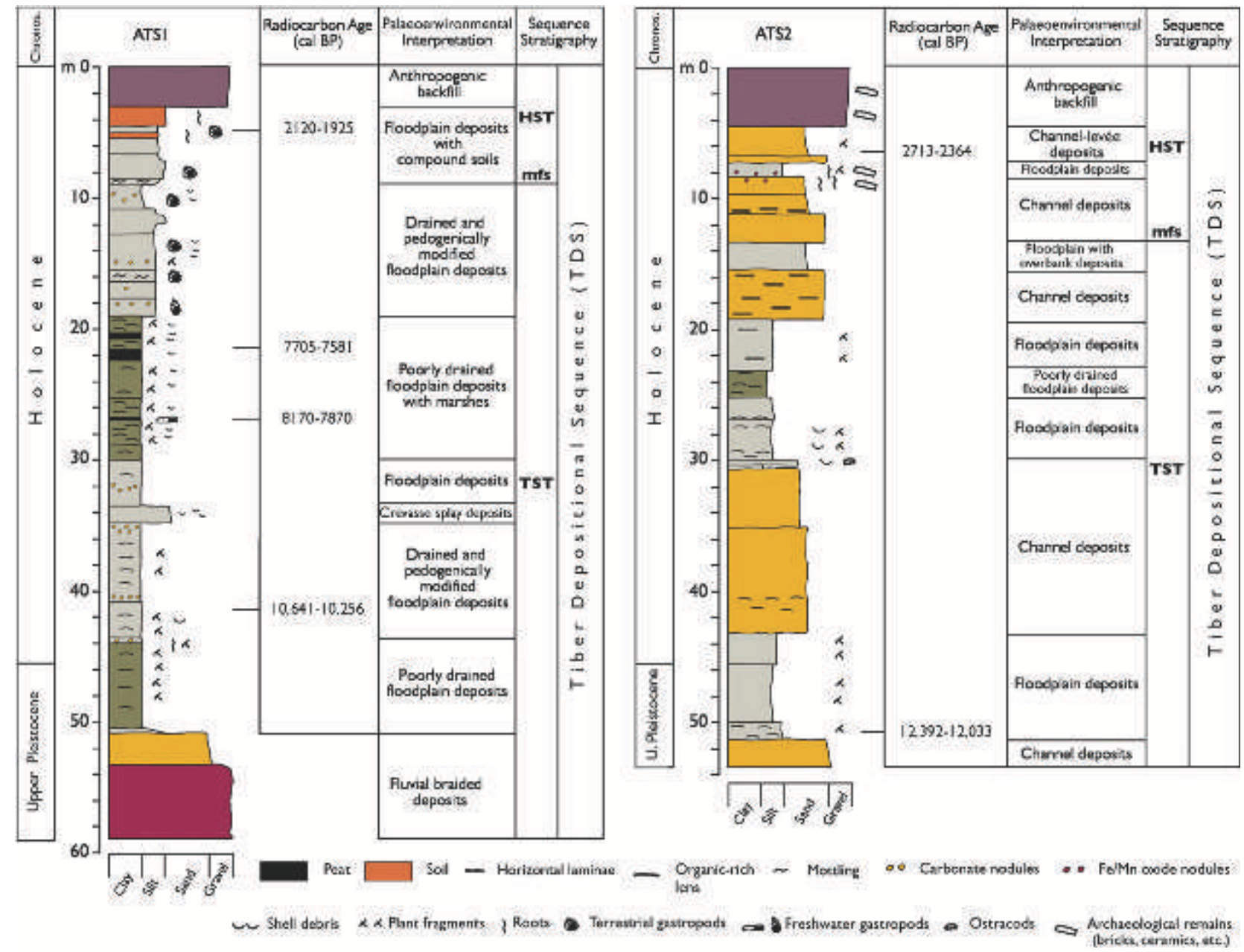

Fig. 13. Stratigraphic columns of the ATS1 and ATS2 cores showing the inferred depositional environments and the sequence-stratigraphic interpretation. HST, Highstand Systems Tract; TST, Transgressive Systems Tract; $m f s$, maximum flooding surface. For location, see Fig. 6.

organic matter and shell debris. No direct data is available about the vegetation assemblage in the Tiber area during the late lowstand. However, in surrounding areas, lacustrine (Follieri et al., 1988) and marine pollen records (Russo Ermolli \& Di Pasquale, 2002), suggest that the vegetational landscape of the Tyrrhenian coast was herb-dominated, with a modest presence of deciduous trees suggesting a relatively arid and cold palaeoclimate during the late lowstand.

The top of the late LST should coincide with the 'maximum regressive surface' (Helland-Hansen \& Martinsen, 1996) that occurs atop the late lowstand Tiber delta deposits. This surface is placed above the forced regressive deposits landward and merges with the TDS boundary where the early lowstand deposits are lacking. (see further discussion) (Fig. 7). The late low- stand and underlying early lowstand deposits are dissected by normal faults found in the delta segment of the TDS and sealed by younger transgressive deposits (see seismic section in Bigi et al., 2014).

\section{Transgressive Systems Tract}

The TST is the most developed systems tract of the Tiber depositional sequence (Fig. 11B to E). It corresponds to the post-glacial deposits that accumulated under rising sea-level conditions between $14 \mathrm{ka}$ and 6 to $5 \mathrm{ka}$ BP. Such deposits onlap directly onto the TDS boundary and locally on the early lowstand deposits (Fig. 7). These deposits also show a facies distribution and a stratal architecture characterized by a retrogradational stacking pattern of the deposi- 


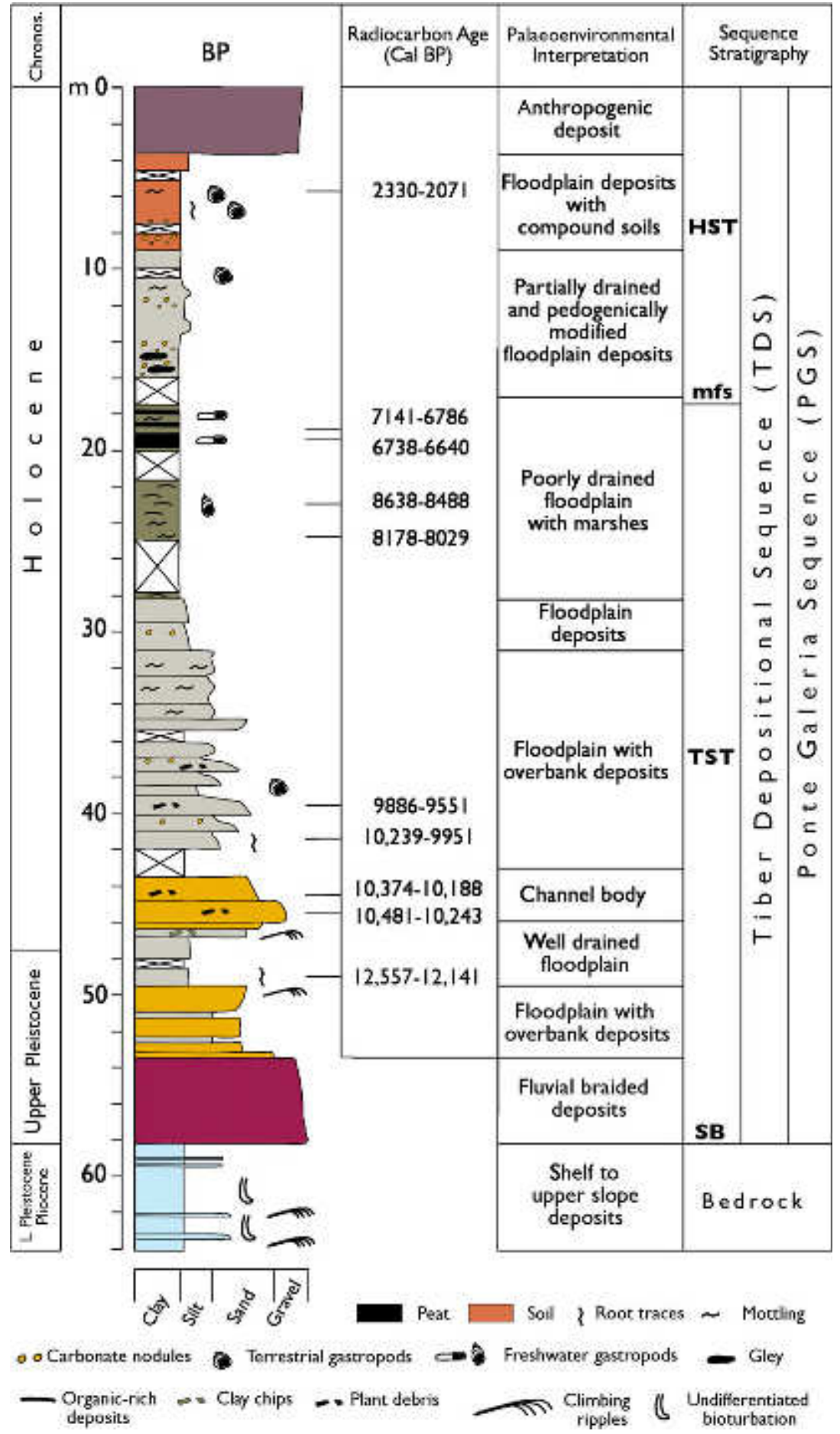

Fig. 14. Stratigraphic column of the BP core showing the inferred depositional environments and the sequencestratigraphic interpretation. HST, Highstand Systems Tract; TST, Transgressive Systems Tract; SB, sequence boundary; $m f_{s}$, maximum flooding surface. Note in this case that the sequence boundary of the low rank TDS and the high rank PGS coincide. For location, see Fig. 6.

tional systems, which include, from landward to seaward: a relatively sinuous fluvial system, a few bayhead deltaic bodies, a coastal-barrier- lagoon system and, finally, a transition to shelf system. The complex interfingering between these depositional systems was the response to 


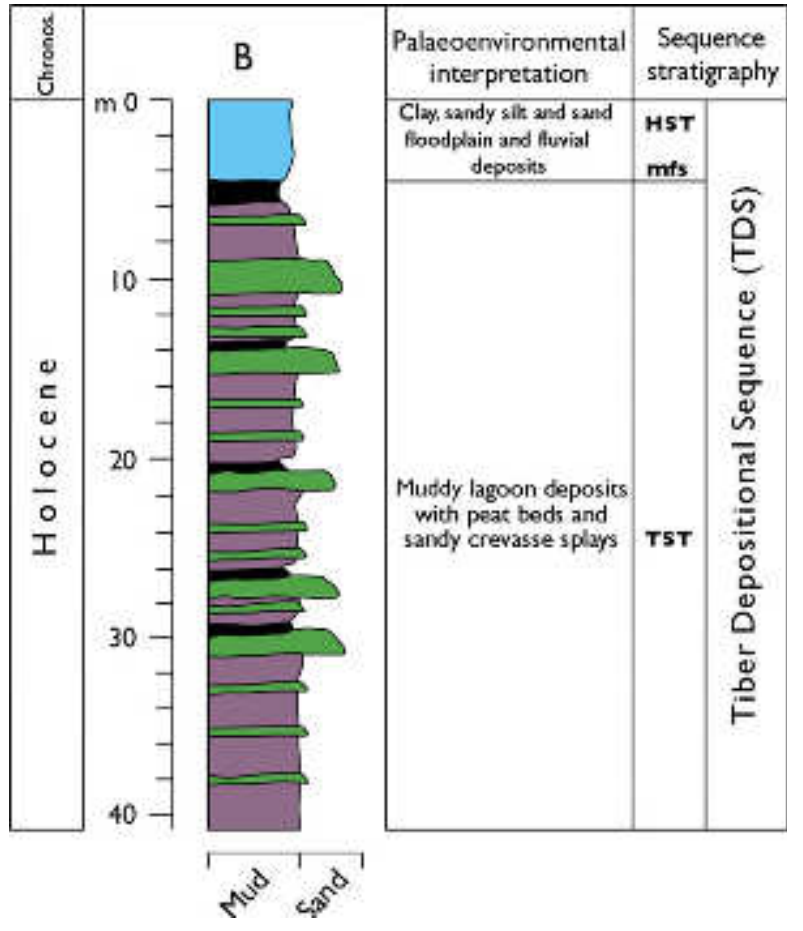

Fig. 15. Stratigraphic column of the B core showing the inferred depositional environments and the sequence-stratigraphic interpretation. HST, Highstand Systems Tract; TST, Transgressive Systems Tract; $m f s$, maximum flooding surface. For location, see Fig. 6.

the onset of transgression and the concomitant transformation of the initial Tiber-incised valley into a wave-dominated estuary (sensu Dalrymple et al., 1992; Nichol et al., 1994; Boyd et al., 2006). This depositional setting is also recognized in late-glacial and Holocene transgressive successions characterizing other Mediterranean deltaic systems (see Somoza et al., 1998; Amorosi et al., 2005, 2008, 2013; Boyer et al., 2005; Labaune et al., 2005; Aguzzi et al., 2007).

The fluvial system develops, essentially, within the Tiber-incised valley and is characterized by two main architectural elements: (i) a channel-belt complex; and (ii) a coeval floodplain bordering the river channels (Fig. 7). The channel complex is arranged into a series of vertically stacked active channel bodies with minor levée deposits, which are recurrent and almost regularly repeated in the channel complex. Channel bodies, in fact, internally show pervasive small-scale and medium-scale crossstrata and a fining-upward trend with mediumcoarse sands at the base passing upward to fine silty sand often closed at the top by a mud plug (Figs 12B to 14). As a result of correlation panels it was estimated that fluvial channels are 6 to $10 \mathrm{~m}$ thick and 400 to $800 \mathrm{~m}$ wide in strike section, having a width/ thickness $(W / T)$ ratio variable from 40 to 130 . The reconstructed channel belt at various depths shows a sinuosity pattern suggesting laterally accreting side bars typical of a meandering channel.

Floodplain deposits are constituted of soft grey-bluish clay and mud, very rich in organic matter, freshwater gastropods and reotrophic peat layers (Fig. 12C); they contain overbank and crevasse splay sandy silt deposits, as well as sand bodies constituting the filling of abandoned channels. The radiometric dating of these sediments has allowed estimation of the floodplain aggradational rates during the TST, as having values ranging from $7 \mathrm{~mm} \mathrm{yr}^{-1}$ (lower portion of the TST) to $15 \mathrm{~mm} \mathrm{yr}^{-1}$ (upper portion of the TST) in the subsurface of Rome, just below the maximum flooding surface (Fig. 7).

The bayhead deltaic bodies constitute the deltaic systems that the Tiber River built into the coastal-barrier lagoon during the sea-level rise phase. Three composite lenticular sandy bodies, named in order of decreasing age as T1, T2 and T3, have been identified; their thicknesses ranges from 5 to $21 \mathrm{~m}$ and they extend from $5 \cdot 6$ to $1.4 \mathrm{~km}$ in strike direction (Fig. 7, cross-section $d-d^{\prime}$ ). These deltaic bodies show a general coarseningupward trend and are composed of two main lithofacies. The first is prevalent in the upper part of each deltaic body and is composed of medium and fine sands, with vegetal remains and a virtual absence of fauna. It is interpreted to be related to mouth bar (delta front) deposits. The second lithofacies shows transitional contact with the previous one. It is constituted of fine sand with intercalations of thin silty clay layers and is considered to represent upper prodelta deposits. The latter shows gradational contacts with the muddy deposits of the coastal lagoon, which is the sector with the lowest energy where peat and other organic matter deposits occur at different stratigraphic levels, and where the brackish environment is also indicated by the foraminiferal, mollusc, ostracoda and pollen assemblages (Fig. 7, cross-section $d-d^{\prime}$ ) (Di Rita \& Magri, 2012; Milli et al., 2013; Di Rita et al., 2015).

The geometry and lateral extension of the deltaic bodies, as well as their sedimentological characters, faunal and vegetation assemblages and the overall depositional context, suggest that they can be considered river-dominated del- 


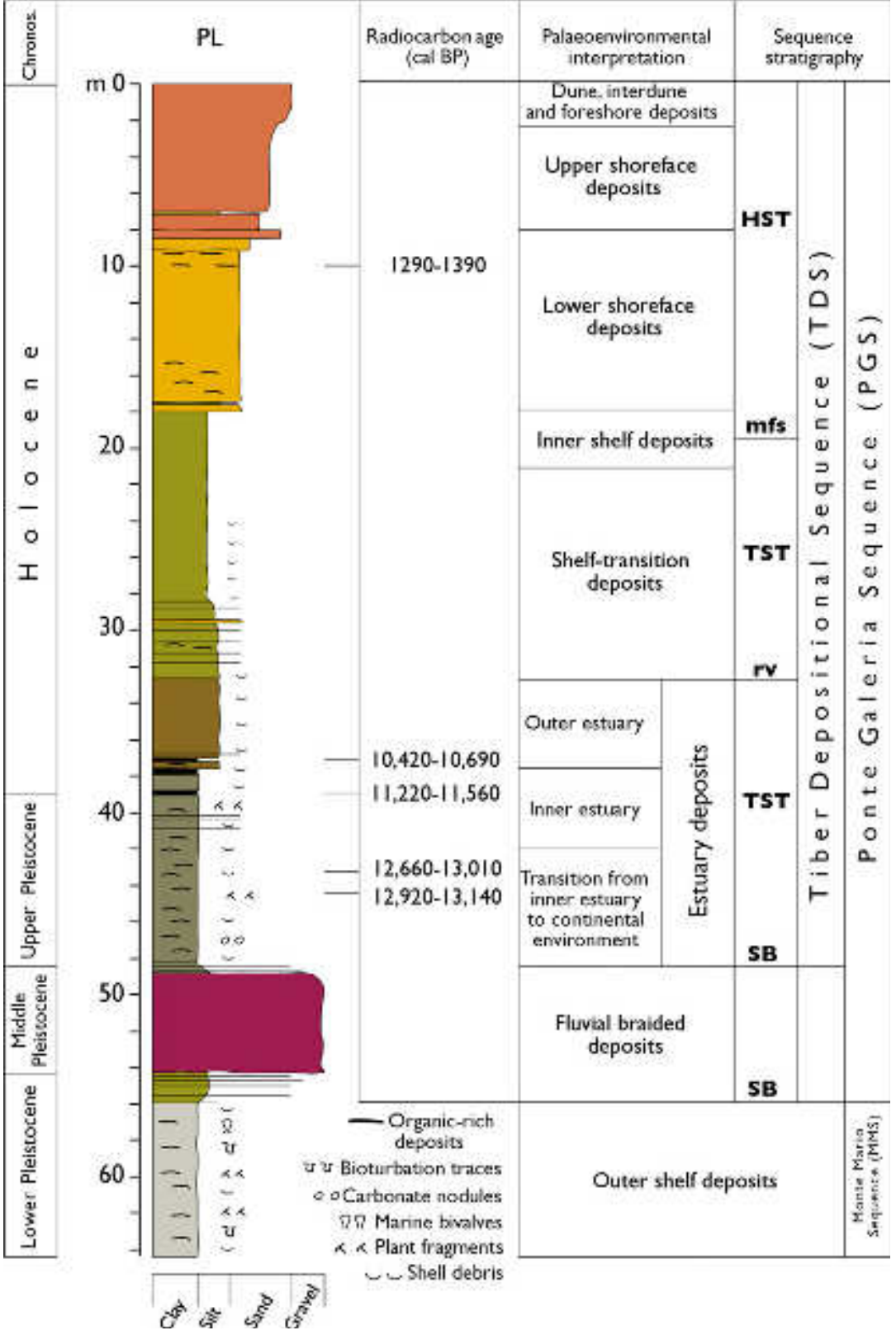

Fig. 16. Stratigraphic column of the PL core showing the inferred depositional environments and the sequence-stratigraphic interpretation. HST, Highstand Systems Tract; TST, Transgressive Systems Tract; $m f s$, maximum flooding surface; rv, ravinement surface. For location, see Fig. 6. Modified from Milli et al. (2013). tas having a series of distributary channels and related mouth bars. The close spacing of one channel to another and their probable lateral migration did not allow for the development of real interdistributary bays. However, it gave rise to the formation of extensive composite lenticular bodies, in which the bars interfingered with one another according to a principle of compensation. The development of these deltaic bodies was conditioned by the hydrodynamic regime of the lagoon, by the variation in discharge and sediment supply of the Tiber River and by the rate of sea-level rise.

The coastal-barrier-lagoon system is the most extensive depositional system developed during the post-glacial sea-level rise (Fig. 7). The barrier bodies are stacked to form a retrogradational pattern; they are 5 to $6 \mathrm{~m}$ thick and give rise to coarsening-upward sequences with medium-fine sands in the upper portion (foreshore-upper shoreface), passing downward to dark grey sandy silt with associated shell levels (lower shoreface). The microfauna indicates a coastal environment being characterized by $80 \%$ of benthonic species (Table 2).

The deposits forming the complex lagoon environment are made up of blue-grey mud with frequent intercalations of thin fine sand and sandy silt layers, often associated with peat, and organic and shell debris (Fig. 15). The macro- 


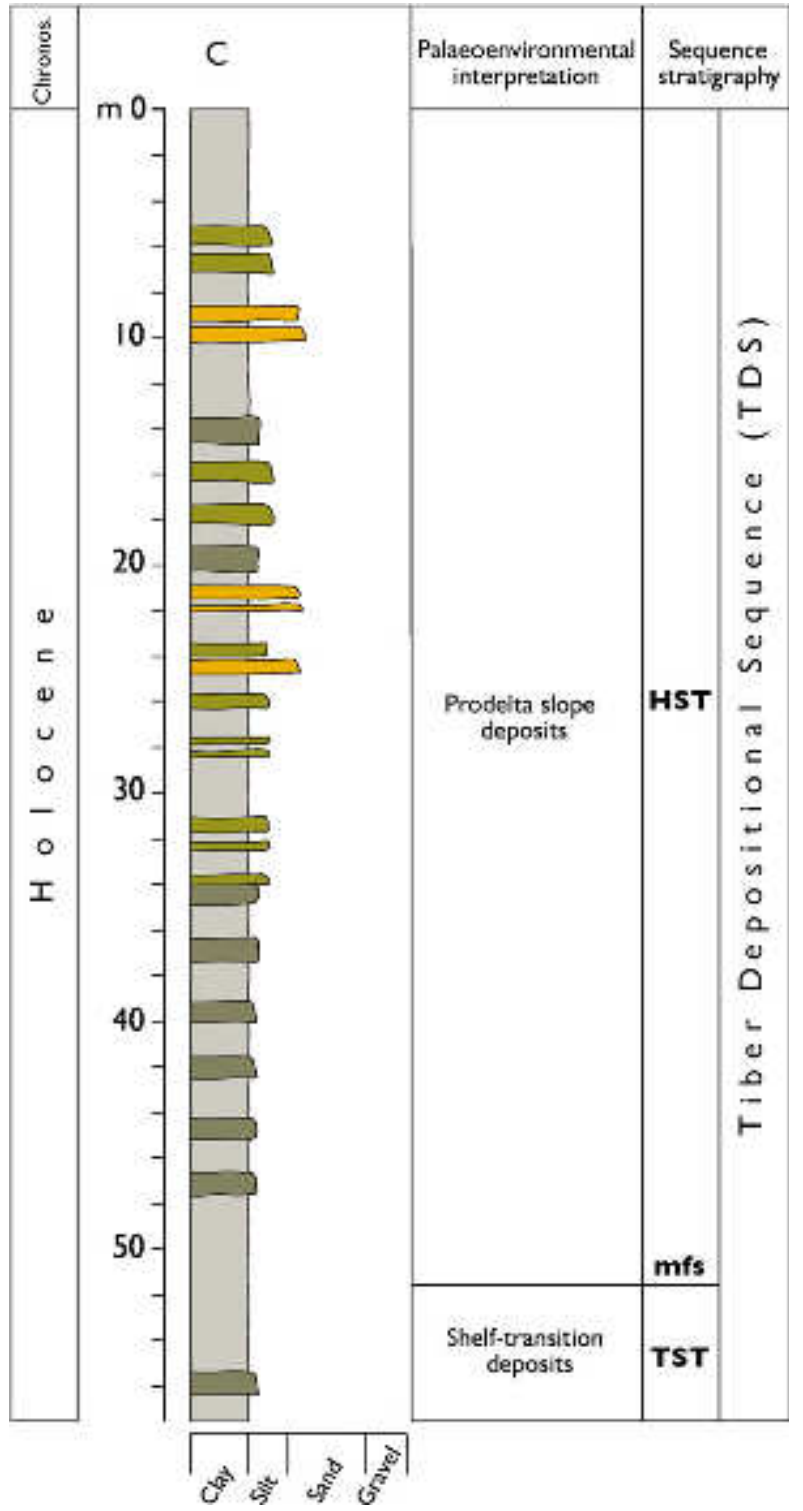

Fig. 17. Stratigraphic column of the C core showing the inferred depositional environments and the sequence-stratigraphic interpretation. HST, Highstand Systems Tract; TST, Transgressive Systems Tract; $m f s$, maximum flooding surface. For location, see Fig. 6. Modified from Bellotti et al. (1994).

fauna includes several levels of oyster shells, and other gastropods belonging to the Hydrobiidae family. The microfauna, together with pollen and plant macrofossils, shows an environmental diversification reflecting the different subenvironments of the lagoon.

The more inland sector is characterized by the absence of microfauna; pollen and plant macrofossil assemblages indicate an open landscape with a strong fluvial influence, where deciduous treee and Pinus are the main elements of the woody vegetation (Milli et al., 2013). The central sector of the lagoon is characterized by microfaunistic (Table 2) and pollen assemblages, as well as plant macroremains suggesting a brackish lagoon-marsh environment. This environment records all the different transitional passages between fresh and marine waters, having a strong trophic gradient and a high salinity variability.

Pollen data, in particular, indicate a welldeveloped marshland, mainly composed of sedge and rushes, with local variations in the arboreal vegetation (see Milli et al., 2013 and Di Rita et al., 2010, 2015, for further details). Peaty mud and peat occur at different depths within the lagoonal mud. They form a more or less continuous layer (from 0.5 to $4 \mathrm{~m}$ thick) and are better developed along the marginal sectors, where marshy deposits occur. The more recent peat layer, ca $12 \mathrm{~m}$ thick, is the most continuous and extensive, and lies 2 to $5 \mathrm{~m}$ below the topographic surface (Fig. 7).

The outer sector of the lagoon behind the barrier islands shows more frequent intercalations of silt and sands associated with wood fragments and shell debris. Such deposits often form sedimentary bodies, $c a 1$ to $2 \mathrm{~m}$ thick, that extend laterally up to $300 \mathrm{~m}$, and have been interpreted as washover fan lobes. The macrofauna and microfauna, and pollen and vegetation assemblages indicate a typical coastal environment with higher salinity. The foraminiferal assemblage is constituted by typical taxa living in shallow water environments with significant organic matter contents and taxa of the normal marine infralittoral environment (Table 2). This may suggest nutrient-rich conditions characterized by a wide availability of food with no oxygen depletion. Ostracod assemblages show a dominance of marine littoral species, although they are often associated with other forms considered to be of brackish-water/marine environments (Table 2; for more details see Milli et al., 2013). Pollen data indicate a strong reduction of grasses, sedge/rushes and aquatic plants for this sector of the lagoon which suggests a reduction of marshy environments. A clear increase in evergreen elements is recorded, indicating the development of a macchia, a typical community of the local coastal environment, indicating a marked reduction of the wetland in favour of sandy soils (Milli et al., 2013; Di Rita et al., 2015).

The transition-shelf depositional systems include the deposits formed seaward of the 
coastal-barrier-lagoon system during the sealevel rise (Figs 7 and 16). These deposits can reach a thickness of $\mathrm{ca} 10$ to $15 \mathrm{~m}$ below the present Tiber delta plain where two main facies associations with transitional contact have been recognized, stacked to form a unit with a finingupward trend. The lower facies association is constituted of an alternation of silty clay and very fine sandy levels, with frequent plant and shell debris and with a benthonic foraminifera assemblage of infralittoral sandy bottoms (Table 2) (Di Bella et al., 2013; Milli et al., 2013). The upper facies association is constituted of silty clay deposits with scattered shell debris, which decrease from the bottom to the top of the interval. The ostracoda and foraminiferal assemblage (Table 2) is substantially similar to the lower interval. The sedimentological features suggest deposition of these sediments in a sector extending from mean storm wave base to mean fair-weather wave base (Reading \& Collinson, 1996). However, it is possible that part of these deposits was the result of flood events.

The depositional systems developed during the TST are better recorded below the present Tiber delta plain and the inland sector. Seaward, in the core taken near the present shelf break, the TST is concentrated in $20 \mathrm{~cm}$ (Fig. 10). This indicates a strongly condensed sedimentation occurring during the rapid sealevel rise (sedimentation rate of $0.019 \mathrm{~mm} \mathrm{yr}^{-1}$ ) (condensed section by Loutit et al., 1988), which produced the landward migration of the Tiber mouth, the shifting of the clastic depocentres related to the other depositional environments and the general starvation on the shelf.

Facies analysis and stratigraphic correlation provide the basis for a detailed reconstruction of depositional environments during the transgressive phase of the TDS (Fig. 11). Small-scale (metre-thick) shallowing-upward cycles (parasequences) showing different facies sequences constitute the building blocks of these deposits, which record a complex interplay between fluvial and marine processes. In particular, these cycles are thought to be the response to a discontinuous relative sea-level rise that was punctuated by stillstand or quasi-stillstand phases, during which depositional systems experienced short phases of progradation and aggradation. In particular, each important step of sea-level rise, marked by a flooding surface at the base of each parasequence, resulted in the following changes from sea to land: (i) barrier migration with abandonment and, possibly, par- tial reworking by marine processes of the old barrier and construction of a new barrier in a more landward position; (ii) bayhead delta abandonment with rapid shifting of river mouths to a more internal location; (iii) increasing accommodation in the coastal plain with widespread development of lagoonal (estuarine) areas over the previously active bayhead deltas; and (iv) aggradation and fluvial channel fill in the Tiber-incised valley. The subsequent sealevel stillstands resulted in the progressive filling of newly formed accommodation space through: (i) lateral migration of the fluvial channels within the incised valley, coupled with mud and fine sand deposition by overbank processes (floodplain environment) and histosol formation (poorly drained palaeosol and swamp); (ii) renewed bayhead delta progradation; (iii) extensive mud deposition, alternating with centimetre-thick sand and shell layers (storm beds) in the lagoonal (estuarine) environments, with an upward transition to laterally extensive organic-rich marsh-swamp deposits; and (iv) beach progradation in the more external parts of the coastal system.

Taking into account what has been described previously, the depositional architecture within the TST can be subdivided into a series of steps recording the sedimentary evolution of the study area, through the interplay between relative and discontinuous sea-level rise and the variation of sediment supply, modulated by the concomitant climatic changes. The early phase of the TST (between $c a 14000$ and $13000 \mathrm{yr}$ cal вр) was characterized by a rapid sea-level rise allowing for the late lowstand Tiber deltaic body to be rapidly drowned and reworked, probably according to the transgressive submergence model of Penland et al. (1988) (Fig. 11B). On top of the delta, a distinct erosional surface (ravinement surface) was formed, representing the transgressive surface separating the lowstand from the transgressive systems tract (Posamentier \& Allen, 1999). Landward, the same transgressive surface separates the underlying late lowstand fluvial and floodplain deposits from the overlying transgressive fluvial and floodplain deposits. In this sector with the baselevel change, the Tiber fluvial valley and the tributary valleys experienced an initial aggradation, while erosion or soil development continued in the surrounding alluvial plain (see also Blum \& Price, 1998; Blum et al., 2013). During this phase, the Tiber River always flowed into the sea again and the deltaic body, due to the 
rapid rise in sea-level, was transformed into an 'erosional headland with flanking barriers' (Penland et al., 1988), at the back of which open lagoons occurred (Fig. 11B).

Between 13000 and 11500 yr cal BP, after the initial and rapid sea-level rise, a slow down occurred during the cold period of the Younger Dryas (YD). Bard et al. (2010) estimate, in fact, before and after the YD, sea-level rise values of $12.1 \pm 0.6 \mathrm{~mm} \mathrm{yr}^{-1}$ and $11.7 \pm 0.4 \mathrm{~mm} \mathrm{yr}^{-1}$, respectively, while a value of $7 \cdot 5 \pm 1 \cdot 1 \mathrm{~mm} \mathrm{yr}^{-1}$ is indicated for this colder period.

With the progressive submersion of the Tiberincised valley, the newly formed barrier island migrated landward (the present authors estimate a shift of the barrier island of nearly $800 \mathrm{~m}$ in ca 1500 years at a rate of $c a 1.8 \mathrm{~m} \mathrm{yr}^{-1}$ ) and a lagoonal basin developed, extending further in the north-west/south-east direction (Figs 7 and 11C). At the mouth of the incised valley within the lagoon, an avulsion process occurred. The Tiber River migrated its course towards the south-east by $c a 2.5 \mathrm{~km}$ with respect to the previous position, giving rise to the formation of the bayhead delta T1. The T1 delta was active until ca $9200 \mathrm{yr}$ BP (see also Bellotti et al., 1994), although its final sedimentation phase was coeval with the onset of deltaic body T2 (Figs 7 and 11D).

The deceleration of sea-level rise during the YD produced a slower rate of accommodation space with some consequences on the stratigraphic organization of depositional systems. In particular, the coastal-barrier deposits are thinner ( $c a 3.5 \mathrm{~m}$ compared to the 6 to $8 \mathrm{~m}$ of the initial phase of the TST), although they show increased lateral extension along the coast. Due to the minor quantity of sediment required to fill the accommodation space, the rate of progradation of the T1 delta increases, with the consequence that it places its mouth just behind the barrier island. At the same time, the $\mathrm{T} 1$ delta also records the maximum lateral extension within the lagoon. In the incised valley, the lowest rate of accommodation space is reflected in a low rate of fluvial channel aggradation and, consequently, in a local increase of channel clustering (see discussion in Posamentier \& Allen, 1999) that produce a greater lateral extension of the meander belt (Figs 7, 11C and 11D).

The last phase of the TST developed between $11500 \mathrm{yr}$ and 6000 to $5000 \mathrm{yr}$ cal BP. After the deceleration of sea-level rise characterizing the YD, a new acceleration phase occurred until 9000 yr BP, followed by a new decrease of the sea- level rise rate documented in the whole Mediterranean area (e.g. Boyer et al., 2005; Lambeck et al., 2011, with references therein). In the valley, this mechanism gave rise to an initial increase in fluvial channel aggradation; this was followed by an increase of the lateral expansion of the meander belt and channel amalgamation due to the decrease of accommodation space (Fig. 7). Because of the short phases of climate deterioration an increase of rainfall occurred, which favoured floodplain aggradation through recurrent flood events, and gave rise to thick overbank and crevasse splay deposits (Figs 7, 13 and 14).

Seaward in the central sector of the estuary, a rapid landward migration of barrier island and Tiber bayhead deltas occurred. The T1 delta was abandoned and a new deltaic body (T2) in the south-eastern portion was formed (Fig. 11D). Due to the greater extension of the lagoonal basin and to the decrease in the rate of sea-level rise (minor accommodation space), a major lateral extension of the T2 delta occurred. The T2 delta was active until ca 8500 yr вP. A new avulsion of the Tiber River and the formation of the bayhead delta T3 (Fig. 11E) occurred during the period of deceleration of sea-level rise related to the cold 8.2 yr вP event (Barber et al., 1999; Clarke et al., 2004). Following this, the T3 delta, fed by a renewed sediment supply, prograded very rapidly within the lagoon (the present authors estimated a progradation of the T3 delta of nearly $1300 \mathrm{~m}$ in $c a 1000$ years at a rate of $c a$ 1.2 to $1.5 \mathrm{~m} \mathrm{yr}^{-1}$ ), reached the coastal barrier and flowed into the sea, giving rise to the initial construction of the present-day, wave-dominated delta.

The final sedimentation phase of the TST is marked into the lagoon by the presence of a thick and continuous peat layer, dated between 6000 and $5000 \mathrm{cal}$ вр (Fig. 7, cross-section $d-d^{\prime}$ ). This layer was formed when sediment supply was concentrated to feed the nascent wavedominated delta. In the lagoon, sediment supply was insufficient and the available accommodation space was filled by peat (see also discussion in Church \& Gawthorpe, 1994: Hampson et al., 1999; Gibling et al., 2004), which grew during the very slow rise of the groundwater table, in turn related to the very slow rise of the eustatic sea-level (see also Bohacs \& Suter, 1997; Jerrett et al., 2011; Van Asselen, 2011). The top of the peat layer coincides with the maximum flooding surface ( $m f_{S}$; Fig. 7 , cross-section $\left.d-d^{\prime}\right)$. In the inland sector, the $m f_{s}$ is placed at the top 
of fluvial deposits, which show a marked channel amalgamation as an expression of the reduced accommodation space (Fig. 7). In the sector below the present Tiber delta plain, the $m f s$ locally coincides either with the boundary between the transgressive barrier sands and the overlying muddy and silty-sand transition-shelf deposits belonging to the HST, or is placed above the transgressive lagoon deposits. In both cases, the $m f s$ is also coincident with the ravinement surface. Seaward, the $m f s$ is located in the lower part of the transition-shelf muds. Here the passage from TST to HST is marked by a distinctive vertical variation from deeper to shallower microfossil assemblages (Fig. 17). The $m f_{s}$ also coincides with the first transgressive surface (ravinement surface) on top of the late lowstand Tiber delta (Fig. 7). The $m f s$ has also been recognized in the core deposits located near the present shelf break at the top of the thin transgressive deposits, where a peak in the plankton percentage occurs (Di Bella et al., 2013). Such deposits, $20 \mathrm{~cm}$ thick, are considered to be the expression of the condensed section (Fig. 10).

\section{Highstand Systems Tract}

The HST developed from 6000 to $5000 \mathrm{yr}$ вр, when sea-level rise decreased to less than $1 \mathrm{~mm}$ $\mathrm{yr}^{-1}$ (Bellotti et al., 1995, 2007), approaching a relatively stable position. During the highstand phase, sediment supply exceeded the rate at which new accommodation space was created, leading to extensive seaward progradation and forming the basis for the development of the present-day Tiber delta. The overall progradational trend occurred with a coeval slow rise of relative sea-level, which produced a slow alluvial plain aggradation and a likely increase in the channel clustering. In the main Tiber River trunk floodplain, the aggradational rate is in the order of 2.8 to $3.0 \mathrm{~mm} \mathrm{yr}^{-1}$. Deposits are composed of overconsolidated, grey to greenish and pale brown clay, mud and silt with rare peat layers, while dry palaeosols, rich in carbonate concretions, Fe/Mn oxides nodules, terrestrial gastropods and root traces, are found frequently (Fig. 11D and E). Channel bodies are commonly composed of fine-grained laminated sands (Fig. 12E) associated with silty-sandy levée facies and minor inactive channels, interpreted as meander cut-off or chute channels filled with fine sediments. Single channels tend to be wider than the underlying transgressive deposits and form a channel-belt complex with a higher degree of lateral amalgamation. This confers a higher lateral continuity of sands (Fig. 7), and probably an enhanced sinuosity as an effect of the channel clustering (see also Schumm, 1993 and Posamentier \& Allen, 1999).

In the coastal plain, the decrease of accommodation space favoured the rapid progradation of the bayhead delta, T3, within the lagoon, which was split into two marshy coastal ponds (Stagno di Maccarese to the north and Stagno di Ostia to the south), poorly and intermittently connected to the sea. These coastal ponds were reclaimed in 1884 (Amenduni, 1884).

The stratigraphic architecture of the HST is dominated by the well-developed wave-dominated, cuspate delta, with lateral transition to strandplains fed by a longshore drift. Readers are referred to several papers about the morphology and depositional processes of the presentday delta (Bortoluzzi et al., 1982; Caputo et al., 1987; Bellotti et al., 1993, 1994; Tortora, 1995; Bellotti \& Tortora, 1996, and references therein).

Below the low-relief dunes and beach ridge complexes forming the present delta plain, a classic coarsening-shallowing-upward sequence, including delta front sands prograding onto prodelta clay/sand alternations, develops. The stacking pattern recognized below the present delta plain and seaward through a high-resolution seismic profile (Fig. 7) shows prograding clinoforms characterized by high-amplitude, continuous internal reflections that commonly thin downdip, giving rise to downlap terminations in the outer shelf (Bellotti et al., 1994). Here, core sediments show typical foraminiferal assemblages with temperate and tropical/subtropical taxa, although small climatic changes can be highlighted through planktonic foraminiferal fluctuations and the isotopic curve (Di Bella et al., 2013).

Facies analysis of the cores along the coast near the Tiber mouth and in correspondence with lateral beach ridges reveals a cyclic grainsize variation and an alternation of beach and lagoon (from open to closed) environments. The present authors interpreted these variations as the expression of the lateral variability of the sandy bodies and the way they have accreted over the past 6000 years. Between 6000 and $2700 \mathrm{yr}$ BP, deltaic progradation gave rise to amalgamated beach ridges forming a sandstone body, ca $20 \mathrm{~m}$ thick, with a coarsening-upward trend. Beach ridges have a regular and quasisymmetrical distribution on both sides of the river mouth, thus suggesting a main wave direction from the western sectors. 
Starting from $2700 \mathrm{yr}$ вP, a noticeable change occurred concomitantly with a cold climatic phase. Unlike earlier stages, the beach ridges that have developed over the past 2700 years show an initial asymmetrical distribution with respect to the Tiber mouth, suggesting that a wave direction from the southern sectors has begun to be more influential. At this stratigraphic level, sandy beach ridges are not amalgamated but separated by muddy deposits that contain organic material and a brackish fauna, thus indicating a lagoon or a slightly confined infralittoral environment affected by a freshwater influence (Milli et al., 2013). All of these features allowed interpretation of these deposits as the expression of barrier-spit systems, whose formation and evolution should follow the mechanism proposed by Bhattacharya \& Giosan (2003), Giosan et al. (2005), van Maren (2005), Giosan (2007) and Dan et al. (2011). The interaction between flood events and the waves were responsible for sand transport towards the shoreline and along shore, giving rise to sand bodies attached to the river mouth. Over time, the emersion of these sand bodies would generate elongated shore-parallel sandy barrier-spits at the back of which fluvial and lagoonal deposits occurred. Moving from the mouth, the continuous elongation of these barrier-spits would have conferred them a cuspate geometry and the attachment to their downdrift tip to the mainland, a process favoured by the alongshore and cross-shore sediment transport. As a consequence of this process, backwater lagoonal basins were transformed into brackish coastal lakes and then into freshwater marshes, which over time were covered by dune and interdune deposits.

Available data document a very complex palaeoenvironmental evolution of the Tiber River over the last 6000 years (Giraudi, 2004, 2011; Bellotti et al., 2007, 2011; Giraudi, et al., 2009; Goiran et al., 2009; Di Rita et al., 2010, 2015; Di Bella et al., 2011, 2013; Jouannic et al., 2013; Milli et al., 2013). These studies highlight that major environmental changes were largely induced by a marked climatic variability. The latter, typical of the Holocene period, was characterized by slight cooling intervals separated by as many warming phases (see Mayewski et al., 2004, with references therein) and, subordinately, by human impact. Based on these data, the evolution of Tiber River delta over the last 6000 years can be subdivided into three different phases.
The first phase spans between $6000 \mathrm{yr}$ and $2700 \mathrm{yr}$ вP (Fig. 11F). At the beginning of this phase, the Tiber acquired a marine mouth (6000 to $5700 \mathrm{yr}$ вP). A cuspate delta with several beach ridges (strandplain) was built over the area, stretching from the present Capo due Rami to the site where the Trajan Imperial harbour was subsequently built (see also Giraudi, 2004; Bellotti et al., 2011; Milli et al., 2013). The internal margin of this strandplain marks the innermost limit of the transgressive coastal barrier. Starting from this point, the Tiber delta prograded seaward at a rate of at least $1 \mathrm{~m} \mathrm{yr}^{-1}$. Microfaunistic data in the more seaward sector (outer shelf) (Di Bella et al., 2013) indicate that between $4700 \mathrm{yr}$ and $3500 \mathrm{yr}$ BP a short cold interval occurred. The benthonic foraminiferal assemblage shows an increase of opportunistic taxa, suggesting stress conditions at the sea floor due to an oversupply of organic matter. This process is consistent with the progradation of the Tiber delta and the increase of sediment supply. It is noteworthy that during this period the sedimentation rate in the outer shelf sector is estimated to be $0.45 \mathrm{~mm} \mathrm{yr}^{-1}$, a value that is an order of magnitude greater than the rate of sedimentation recorded in the TST. Also in this sector, a decrease of the sedimentation rate to $0.28 \mathrm{~mm} \mathrm{yr}^{-1}$ has been recorded for the last 3000 years, probably in connection with the beginning of human activity, although the Tiber experienced alternating phases of erosion and progradation.

Landward, pollen data (Bellotti et al., 2011; Milli et al., 2013) indicate that towards the end of this phase, the landscape was covered by a mixed oak-dominated woodland with evergreen elements, suggesting an expansion of forest communities on the newly available land produced by the cuspate delta accretion. This also encouraged human activity that, during the transition from the first to the second phase (7th Century $\mathrm{BC}$ ), promoted the foundation of ancient Ostia, as suggested by historical accounts (Bellotti et al., 2011).

The second phase (Fig. 11G) spans from 2700 to $1900 \mathrm{yr}$ вр. This phase was characterized by the alternation of two cool and warm periods, as evidenced by foraminiferal assemblages, oxygen and carbon isotopic curves (Di Bella et al., 2013), and variations in sediment discharges. An important event characterizing this period was the abrupt southward migration of the river mouth. This probably was the result of a strong flood event that occurred during a cold climatic 
phase recognized in the Mediterranean area (Incarbona et al., 2010) and coincident with the Bond cycle B2 (Bond et al., 1997). The Tiber River flowed into the Ostia pond, thereby opening a new mouth $\mathrm{ca} 3 \mathrm{~km}$ south of the previous one (the present Fiumara Grande mouth). Through the new channel, the Tiber River began to build a new mouth lobe, having an estimated progradation rate of $\mathrm{Ca} 5$ to $6 \mathrm{~m} \mathrm{yr}^{-1}$. About 2350 to $2400 \mathrm{yr}$ BP, the Tiber delta was almost fully developed. After this phase, delta growth was interrupted by a new erosive process that produced the erosion of the beach ridge and the apex of the delta, as suggested by the reconstruction of the shoreline (Bellotti et al., 2011; Milli et al., 2013). This erosive process occurred ca 1650 yr BP (3rd Century AD) during the Roman Warm Period, which was characterized by a decrease in Tiber floods (Bellotti et al., 2011; Giraudi, 2011). Starting from $2400 \mathrm{yr}$ BP onwards, the Tiber evolution was strongly influenced by human activities; these modified the natural landscape through the introduction of cultivated and anthropochore plants, and through important deforestation phases, particularly during Imperial times.

With the third phase (from ca $1900 \mathrm{yr}$ вр to present day) (Fig. 11H), the Tiber progradation gave rise to a complex cuspate delta characterized by two simultaneously active distributary channels: Fiumara Grande, the most important and natural distributary channel, and Fiumicino channel, dredged during the 1st Century $\mathrm{AD}$ for the construction of the Roman Imperial Port. During this period, the Tiber delta experienced alternating phases of progradation, stability and erosion under the control of rapid climatic changes. Nevertheless, the delta progradation was continuous and quite intense (the Tiber delta prograded for $c a 3 \mathrm{~km}$ at a rate of $c a$ $9 \mathrm{~m} \mathrm{yr}^{-1}$ ) over the last 500 years and strictly connected to the Tiber flood events, while the erosion of beach ridges occurred during phases with reduced sediment supply (Bellotti et al., 1994, 2011; Giraudi, 2011; Di Bella et al., 2013; Milli et al., 2013).

Between the 1st Century and 1400 AD, no variations of the shoreline position seem to have occurred. Starting from the middle of the 15th Century and until 1900 AD, a major seaward shift in the shoreline position was recorded in coincidence with the Little Ice Age (between $700 \mathrm{yr}$ and $350 \mathrm{yr} \mathrm{BP}$ ), when more frequent and intense floods were historically documented in the city of Rome in 1530, 1557, 1598 and 1606 AD (water discharge variable between 3500 and $4500 \mathrm{~m}^{3} \mathrm{sec}^{-1}$ versus a present average water discharge of less than $250 \mathrm{~m}^{3} \mathrm{sec}^{-1}$ ). This important phase of Tiber delta progradation is common to other deltaic systems of the eastern Tyrrhenian Sea, although progradation rates are different from place to place and from one delta to another (Caputo et al., 1987; Alessandro et al., 1990; Bellotti, 2000).

\section{INSIGHT FROM THE TIBER DEPOSITIONAL SEQUENCE}

What was described in the previous paragraphs highlights that the Tiber depositional sequence (TDS) shares many characteristics, in terms of stratigraphic and depositional architecture, with other Late Pleistocene to Holocene deltaic and coastal successions of the world (see references in the Introduction). These features suggest that glacio-eustatic sea-level fluctuations played a major role in the stratigraphic architecture of these sedimentary successions, although other factors interacted with eustatic sea-level changes, thus determining the conditions for a more complex evolutionary history of the deltaic apparatus.

In the case of the Tiber River, the combined effect of eustatic changes, tectonic uplift of the coastal sector and coeval subsidence of the continental margin played an important role in determining: (i) the genesis of a mixed bedrockalluvial valley (sensu Gibling, 2006; Blum et al., 2013) that extends close to the coastal plain and partially to the innermost portion of the shelf; (ii) the formation of a sequence boundary that shows different physical characteristics from landward to seaward and, consequently, a different preservation of the early lowstand deposits moving from landward to seaward; (iii) a depth of the early lowstand delta different than expected from eustatic curves; (iv) a rearward position of the Tiber late lowstand delta with respect to the deposit of the early LST; and (v) a change of the channel pattern and of the stacking pattern of fluvial deposits during the LST, TST and HST. The following discussion takes these points into account.

\section{The mixed bedrock-alluvial Tiber valley}

The sector of the Tiber valley that was investigated has a complex history, with multiple incision and filling phases, reflecting the interaction 
between the tectonic uplift of the Latium continental margin, the glacio-eustatic sea-level fluctuations and volcanic activity. North-west/ south-east and north-east/south-west normal faults are the main tectonic lineaments conditioning the valley direction, the local depocentres and the depositional profile of the coastal plain on which this valley was carved. In particular, the last phase of evolution of the Tiber valley coincides with the sea-level fall occurring at the passage from MIS 5.5 to MIS 2, concomitant with the tectonic uplift of the Latium Tyrrhenian margin (Barberi et al., 1994). During this phase, a deep valley began to form at the Tyrrhenian stage highstand shoreline, which was systematically filled and incised several times. This valley is absent in the middle and outer shelf sectors, because the shelf was separated from the emerged portion of the coastal margin due to the presence of north-west/southeast normal faults (Apennine alignment). Consequently, most of the deposits were eroded and part of the valley-related deposits crop out or are preserved in the subsurface, either as fill of the smaller incised tributary valleys feeding the Tiber River or as early lowstand terraced deposits below the present delta plain. This mechanism implies that the basal surface bounding the Tiber bedrock and the mixed bedrock-alluvial valley (i.e. the TDS sequence boundary) represents a composite and diachronous surface (see discussion in the next section), a feature that is consistent with the observations of many preserved Quaternary successions.

The geometric features of the last Tiberincised valley also show many of the characteristics recognized in other Quaternary valleys and in experimental studies: (i) the basal valleyfill surface develops from multiple episodes of incision and channel-belt formation during relative sea-level fall (early lowstand) (Blum \& Price, 1998; Posamentier \& Allen, 1999; Blum \& Törnqvist, 2000; Amorosi \& Milli, 2001; Blum \& Aslan, 2006; Martin et al., 2011; Holbrook \& Bhattacharya, 2012; Blum et al., 2013); as such, the final valley at the end of the sea-level fall can be considered a composite geomorphological element that is wider than the single surface valleys that created it (Fielding \& Gibling, 2005; Gibling, 2006; Sheets et al., 2007); (ii) it deepens and widens downstream due to the base-level fall, the increases in sediment flux from valley excavation and its deposition (Cantelli et al., 2004; Strong \& Paola, 2009; Martin et al., 2011). It also deepens progressively landward because of knickpoint migration upstream. The widening of the Tiber valley probably also increased during the subsequent base-level rise characterizing the late LST and the TST, due to lateral erosion of the valley walls and the contemporaneous deposition and filling (vertical aggradation) of it; (iii) most of the sediments filling the inland sector of the Tiber valley and of their tributaries show a fining-upward trend, having fluvial deposits at the base, passing upward to lacustrine and, in some cases, lagoonal deposits, thus reflecting the general landward backstepping of the depositional systems.

\section{Significance of sequence boundary}

Complexity and significance of the sequence boundaries have been the subject of recent research papers (see Holbrook \& Bhattacharya, 2012; Blum et al., 2013; with references therein), highlighting the diachronous and composite character of this surface, a feature also evidenced and discussed by Posamentier \& Allen (1999) and, more recently, by Catuneanu et al. (2009, 2011).

In the opinion of the present authors, a large part of the problem lies in the hierarchical significance that is attributed to these surfaces within the stratigraphic framework of the analysed sedimentary succession. The Late Pleistocene Tiber River deposits, more specifically those that form at the transition between MIS 5.5 and MIS 2, are surely appropriate for discussion of these concepts.

The sea-level fall occurring at the passage from MIS 5.5 and MIS 2 is substantially discontinuous, as well as the other sea-level eustatic falls during the Pleistocene, and is characterized by higher frequency (low rank) cycles superimposed on the lower-frequency (high rank) sealevel cycle. This results in the formation of higher frequency sequences that stack to form high rank composite sequences. In light of this, the TDS represents a composite sequence, which resulted in the superimposition of higher frequency sequences developed on interval times of a thousand years. Following the concept of a sequence as a unit that may develop at any spatial and/or temporal scale (Catuneanu et al., 2009, 2011), it is evident that the low rank sequences can also show stratal geometries with LST, TST and HST, whose potential preservation is strictly related to the intensity of erosion and deposition processes occurring during a full cycle of change in accommodation. When pre- 


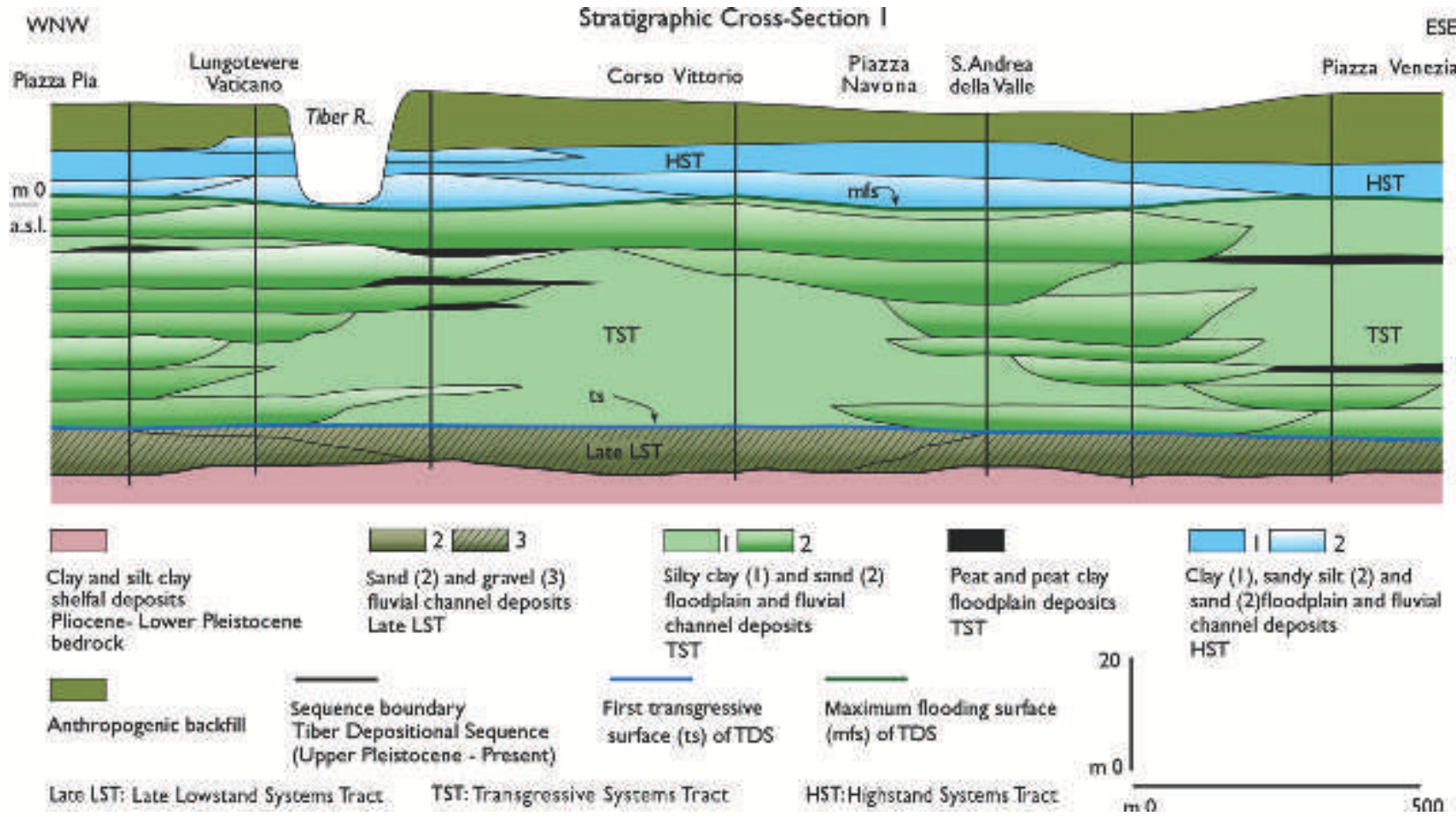

Fig. 18. Stratigraphic cross-section showing the depositional architecture of the Tiber valley fill in the centre of Rome. For the tracks of cross-sections see Fig. 6.

served, these sequences, such as in the case of the Tiber River, are bounded above and below by unconformity surfaces; they are stacked in such a way that the oldest sequences are shifted landward and topographically higher when compared to the younger ones, which are shifted seaward and topographically lower. The partial or total preservation of these low rank sequences affects the significance attributed to their bounding surfaces and, in turn, to the sequence boundary of the high rank sequence they belong to. Therefore, the sequence boundary models proposed by Holbrook \& Bhattacharya (2012) (cut and cover, and bypassing) are, in the opinion of the present authors, nothing more than different physical expressions of the sequence boundaries under the effect of the same process, i.e. the high-frequency/high-amplitude baselevel/sea-level change. These are often in combination with other factors, such as for example: (i) the type of sediments and rocks constituting the substrate where the erosive processes occur; and (ii) superimposition on the glacial eustasy of local factors like tectonic uplift and/or volcanic activity that can promote or counteract sedimentation, determining the conditions for a major or minor preservation of the early lowstand deposits and, consequently, of their bounding surfaces. The consequence of this is that a sequence boundary represents a complex surface recording several processes working during its formation. Such processes are directly responsible for the final physical expression of this surface that simultaneously and locally can be a bypassing surface or is buried by fluvial or marine sediments (cut and cover model; Holbrook \& Bhattacharya, 2012; Blum et al., 2013).

The TDS boundary shows both of these characteristics. In the inland sector, where the early lowstand deposits almost are not preserved, the TDS boundary coincides with the boundary of the incised valley (Figs 7 and 18 to 21). It is a classical subaerial unconformity representing a topographic surface where sediment bypassing occurred, subsequently buried by backfilling during relative sea-level rise. Below the present delta plain, the partially preserved early lowstand deposits form terraced units within the valley (Fig. 7, cross-sections $c-c^{\prime}$ and $d-d^{\prime}$ ). Here the TDS boundary is a 'composite valley-fill unconformity' (Blum \& Aslan, 2006; Strong \& Paola, 2009; Martin et al., 2011; Holbrook \& Bhattacharya, 2012; Blum et al., 2013) (Fig. 21). Also within the valley, below the delta plain, the top of the terraced early lowstand deposits coincides with the maximum regressive surface (MRS) that 


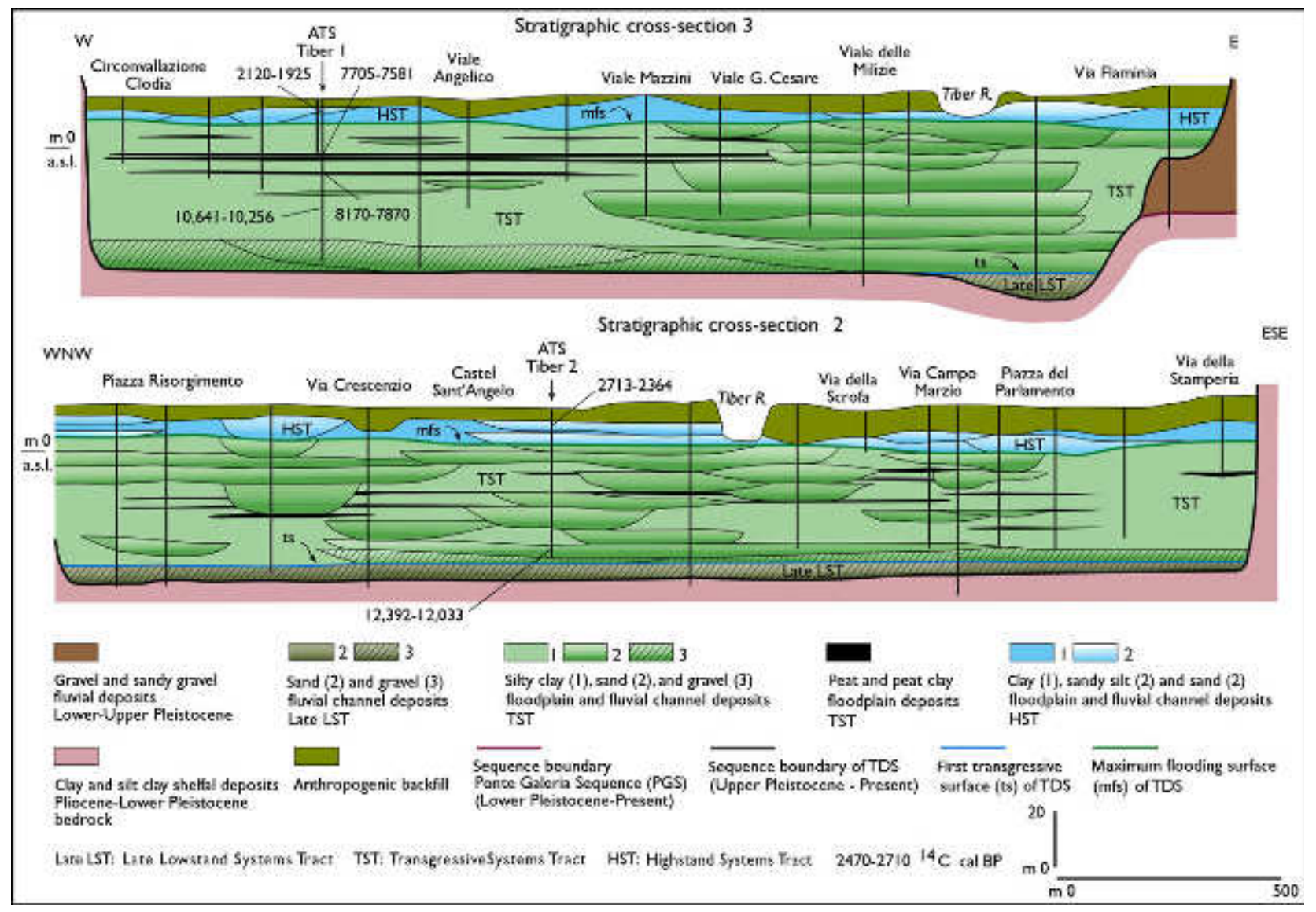

Fig. 19. Stratigraphic cross-sections showing the depositional architecture of the Tiber valley fill in the centre of Rome. For the tracks of cross-sections, see Fig. 6.

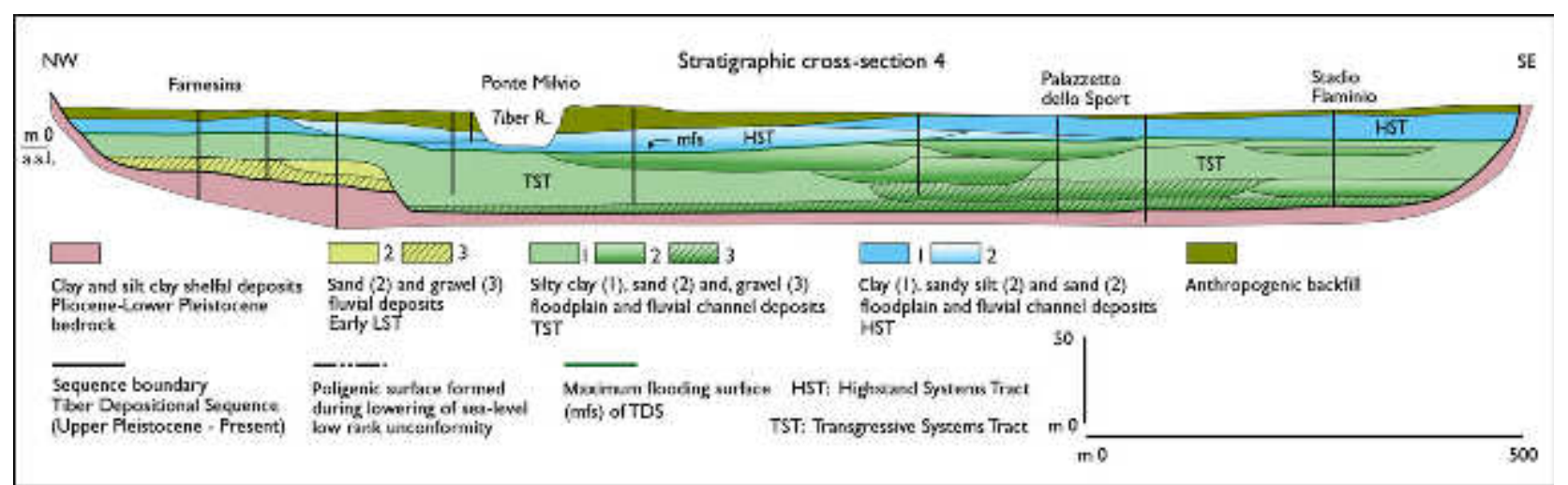

Fig. 20. Stratigraphic cross-sections showing the depositional architecture of the Tiber valley fill in the centre of Rome. For the tracks of cross-sections, see Fig. 6.

merged in the interfluvial sector with the TDS boundary (Fig. 7, cross-section $d-d^{\prime}$; Fig. 21). The MRS is onlapped by lagoonal and, locally, by Tiber bayhead delta deposits during the transgressive phase (TST). Moving seaward, the TDS boundary returns to be a subaerial unconformity below the present delta front (inner shelf sector). Then it shows the character of a regressive surface of marine erosion in the middle and outer shelf sectors and, finally, becomes a correlative conformity on the continental slope (Fig. 7, cross-section $a-a^{\prime}$; Fig. 21). 


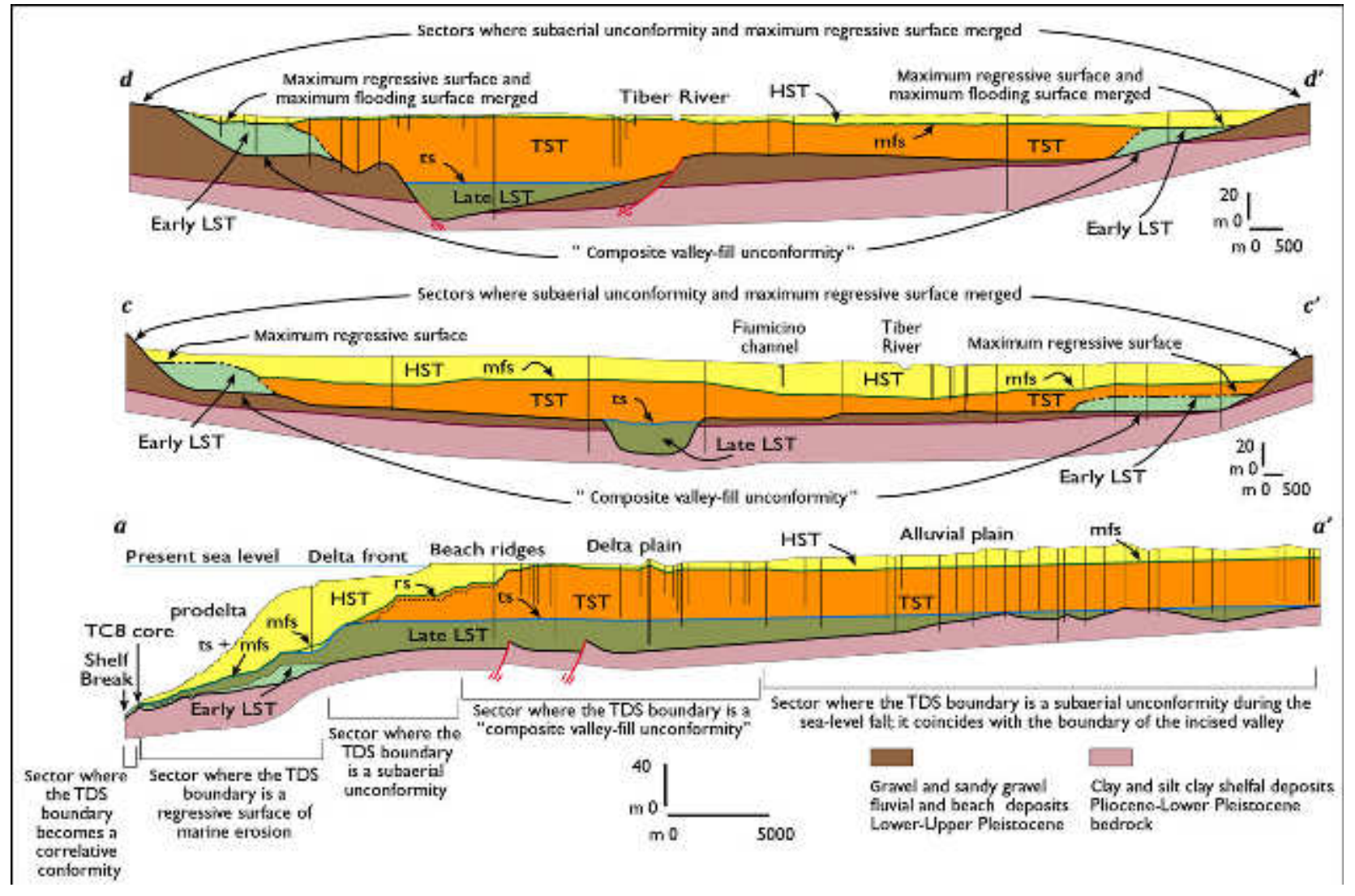

Fig. 21. Simplified cross-section of the Tiber depositional sequence (TDS) evidencing the different physical expression of the TDS boundary in dip (cross-section $a-a^{\prime}$ ) and strike direction (cross-sections $c-c^{\prime}$ and $d-d^{\prime}$ ) and its diachronous and composite character. Note that the terraced early lowstand systems tract (LST) deposits of the TDS constitute the deposits of lower rank depositional sequences, formed during the sea-level drop following the highstand phase related to substage $5 \mathrm{e}$.

These elements show the composite and diachronous origin of the TDS boundary (Amorosi \& Milli, 2001), a feature which is wellremarked in recent papers (Blum \& Aslan, 2006; Strong \& Paola, 2009; Martin et al., 2011; Holbrook \& Bhattacharya, 2012; Blum et al., 2013), and that implicitly and explicitly characterizes all the stratigraphic surfaces, independent of their time and mechanism of formation.

\section{Depth of the Tiber early lowstand delta}

Concerning the depth reached by the early lowstand delta at the end of the sea-level fall, which is of a different value than that deduced from the eustatic curves based on the Pleistocene composite $\delta^{18} \mathrm{O}$ record (see Cohen \& Gibbard, 2011), the close interaction between the eustatic sea-level fall, the tectonic uplift and volcanism of the Latium coastal margin must be considered. Considering only the glacioeustatic effect, Peltier \& Fairbanks (2006) estimated that the peak of the post-Tyrrhenian sea-level fall, coinciding with the LGM expansion, was at $c a 120 \mathrm{~m}$ below the present sealevel. Taking into account that, in the Mediterranean area, the adopted eustatic height of MIS 5.5 is $7 \pm 1 \mathrm{~m}$ above the present sea-level, a sea-level fall of $c a 127 \mathrm{~m}$ is suggested by these data.

Along the Latium Tyrrhenian margin, extensional tectonics have been active since the Miocene and the effects of volcanism must be added since the Pliocene. In particular, in the studied area, the inland Pleistocene coastal terraces show a well-evident uplift related to the tectonic and volcanic activity since $500 \mathrm{ka}$ (Cavinato et al., 1992; Milli, 1997; Karner et al., 2001). For the last $125 \mathrm{ka}$, an estimated rate of tectonic uplift of $c a 0.23 \mathrm{~mm} \mathrm{yr}^{-1}$ as related to magmatic intrusion is suggested by Bordoni \& 
Valensise (1998), Nisi et al. (2003) and Ferranti et al. (2006). The resulting geological picture documents the presence of a north-west/southeast oriented crustal thermal bulge with a $150 \mathrm{~km}$ wavelength, substantially centred in correspondence to the Sabatini volcanic district whose effects are also felt blandly along the continental shelf, which is instead affected by a regional thermal subsidence with an estimated rate of $c a 0.21 \mathrm{~mm} \mathrm{yr}^{-1}$ (Fraccascia et al., 2013).

If the effects of the glacio-isostatic and hydroisostatic rebound that produce subsidence in the Mediterranean area with a rate of $\mathrm{Ca}$ $0 \cdot 20 \mathrm{~mm} \mathrm{yr}^{-1}$ (a very conservative estimate) (see Lambeck et al., 2004) and the post-Tyrrhenian sea-level fall rate ( $c$ a $1.3 \mathrm{~mm} \mathrm{yr}^{-1}$ ) are added to this value, the resulting sea-level position in the sector in front of the Tiber River is estimated at ca $90 \mathrm{~m}$ below the present sea-level. The present data therefore suggest that: (i) the lowstand sealevel, $20 \mathrm{ka}$ cal вр, was located at $c a 90 \mathrm{~m}$ below the present sea-level and not at $120 \mathrm{~m}$; and (ii) the lack of an incised valley on the outer shelf in front of the Tiber River is consistent with the previous data, because the sea-level never fell below the shelf break (Fig. 7, cross-section $a-a^{\prime}$ ).

\section{Location of the Tiber late lowstand delta}

A consequence of the processes described in the previous paragraph is the rearward location of the Tiber late lowstand delta with respect to the last deposit of early LST and, consequently, the different progradation/aggradation rates of the late lowstand deposits within the landward and the seaward sectors of the valley. The present authors attribute the stratigraphic setting described above to the different subsidence and tectonic uplift characterizing the outer shelf sector on one hand, and the inner shelf/coastal margin on the other. The latter, uplifting at a greater rate, would have favoured a deep incision of the valley, creating the successive conditions for a major accommodation space: a major thickness of the late lowstand delta deposits, resulting more aggradational than progradational and a rearward position of the delta just at the mouth of the incised valley. However a significant fluvial aggradation during the late lowstand in the upstream sector of the incised valley is not evident, and this could be the different response of the upstream and downstream sectors of the incised valley to the base-level change. Essentially, while in the coastal sector, the Tiber late lowstand delta responded more rapidly to the sea-level rise through an aggradation and a weaker progradation phase, the upstream sector of the incised valley responded with a time lag to this process so that the fluvial aggradation was slower than the aggradation and progradation of the delta. The result of this is the different thickness of the late lowstand deposits, being thicker and thinner in the downstream and upstream sectors of the incised valley, respectively. Alternatively, the reduced thickness of more internal deposits (i.e. the lack of significant fluvial aggradation) with respect to those filling the outer sector may be explained not only by different accommodation between the two sectors, but also by reduced sediment supply due to a reduced catchment area during a cold and relatively arid period (LGM). Further seaward the late lowstand deposits become thinner and downlapped onto the early lowstand coastal systems.

\section{Stacking pattern of channel fluvial deposits during the lowstand systems tract, transgressive systems tract and highstand systems tract}

The change of the channel pattern and of the stacking pattern of fluvial deposits during the LST, TST and HST constitutes an issue that has been discussed in several papers (Miall, 1991, 2006; Schumm, 1993; Wright \& Marriott, 1993; Shanley \& McCabe, 1994; Posamentier \& Allen, 1999; Blum \& Törnqvist, 2000; Holbrook \& Bhattacharya, 2012; Blum et al., 2013). The definition of the channel pattern is complex and as a result is controlled by the change of shape, dimension and widening of the valley as well as by other factors, including stream power, grain size and the presence or absence of mud and/or vegetation inducing bank stabilization (for a detailed discussion see Dade \& Friend, 1998; Dade, 2000; Church, 2006; Peakall et al., 2007; Tal \& Paola, 2007). At the same time, it is also difficult to interpret channel geometry and width only on idealized vertical sequences of lithofacies, although some authors (Bridge \& Tye, 2000; Leclair \& Bridge, 2001; Bridge, 2003) have suggested solutions to this problem (see also the critical contribution of Miall, 2006).

In the case of the Tiber, the data used to estimate the characters of the channel pattern and of the channel-belt width are derived from the examination of several and closely spaced core logs, and by their detailed correlations (Figs 18 
to 20). Nevertheless, some doubts remain because from only the cores it is very difficult to distinguish whether a vertical profile is related to a single channel-fill or records a superimposition of two or more channel-fills (see also discussion in Best et al., 2003; Lunt et al., 2004; Miall, 2006). At the same time, it is not possible to define the degree of channel splitting or the sinuosity of channels, although some elements related to the facies help to better characterize the type of channels. The following discussion is subdivided, considering the characteristics of fluvial style during the LST, the TST and the HST.

Concerning the early LST, the only preserved fluvial deposits occur as old terraced deposits within the Tiber valley below the present delta plain and, doubtfully, in some localized innermost sectors within the incised valley. Such deposits form a sedimentary body with a tabular geometry, 3 to $5 \mathrm{~km}$ wide and 10 to $30 \mathrm{~m}$ thick that has been attributed to a braided depositional system (Figs 7 and 20). On the contrary, the present authors have no evidence of the thickness, width and type of channel pattern of the younger fluvial deposits in the deeper portion of the valley where, instead, the onlapping late LST and TST fluvial deposits occur. However, considering the gradient of the valley and its width, and the nature of the encasing and erodible Pleistocene sediments of the substratum, it is suggested that a sandy and sandygravel-braided channel belt probably developed during the Early LST. The absence, at present, of fluvial deposits in the deeper portion of the valley indicates that a fluvial deposition and a subsequent erosion of the deposits occurred as related to the sea-level fall. In light of this, a preferentially bypassing role of the deeper portion of the valley is suggested during the early LST.

During the late LST, the rise of the base level produced an increase of accommodation and aggradation of fluvial-deltaic deposits in the lower course of the Tiber River. The valley began to fill with fluvial deposits onlapping onto the basal surface of the valley, in turn coincident with the TDS boundary. Fluvial deposits formed a complex of amalgamated channels and occupied almost the entire section of the valley (as can be seen in strike sections). It is possible to measure the thickness of these single channels, varying from 5 to $10 \mathrm{~m}$ and from 8 to $18 \mathrm{~m}$, in only a few sections and also show a decrease of the amalgamation level moving from landward to seaward, respectively. The change of the channel pattern along the axial-valley is suggested, based on the geometry and grain size of the deposits, a characteristic that in turn is related to the base-level rise. Landward, the Tiber received several tributaries transporting gravel and coarse sand derived from the erosion of the Pleistocene fluvial and beach gravel and sandy-gravel deposits cropping out along the flanks of the valley. These coarse deposits thus constitute a product of the cannibalization of the valley flanks. Their presence is consistent with the model of valley evolution previously described and characterized by widening and lateral migration of the channels (Milli et al., 2008; Strong \& Paola, 2009). So, in this sector, a low sinuosity or probably a braided morphology is suggested for the river system, based on the width of the valley and prevailing grain sizes (Figs 18 and 19). Moving seaward, the widening of the valley and the absence of tributaries supplying coarse sediment to the major trunk allowed the Tiber to change its channel morphology, assuming a greater sinuosity and probably a meandering pattern. This situation remained substantially unchanged up to the end of the late LST, although upward in the sections a decrease of grain size occurs as well as a probable increase of the sinuosity of the channels, a feature that would be evidenced by the increase of fine-grained floodplain deposits and local peat beds.

In the TDS, a marked change of channel pattern is found in the TST. In particular, channels are not laterally amalgamated and in general are distinguishable from one another, being separated by floodplain mudstones rich in organic matter, peat layers and sand beds with variable thicknesses, interpreted as crevasse splays and abandoned channel deposits, respectively. The reconstructed channel belt shows at various depths in plan view a pattern of sinuosity suggesting lateral accreting side bars, chute and neck cut-offs that are typical of the meandering style. Channels are arranged into a series of vertically stacked bodies reflecting a rate of accommodation space greater than the rate of sediment supply (Figs 18 to 20). This situation also promoted the build-up of floodplain deposits due to the high sedimentation rate. In the lower and middle portion of TST, the channel-fill thickness varies from 8 to $11 \mathrm{~m}$, and decreases to $c a$ $5 \mathrm{~m}$ just below the $m f s$. The width of the channels shows a variation in relation to the width of the valley: where the latter is narrower, chan- 
nels are up to $c a 200 \mathrm{~m}$ wide, whereas where it widens, channels are $c a 750$ to $800 \mathrm{~m}$ wide. The channel widths seem to increase up to $c a 1300$ to $1400 \mathrm{~m}$ in the final stage of the TST just below the $m f s$. The difference in channel width is explained here as being connected to two main factors: (i) the filling of the valley that widens from bottom to top; and (ii) the reduction of accommodation space when approaching the $m f s$. This process should be connected with a deceleration of the relative sea-level rise rate, which allows an increase in the channel clustering and, consequently, a greater amalgamation between channels. The initial and intermediate phases of the TST are, in fact, characterized by a relative sea-level rise rate greater than $10 \mathrm{~mm} \mathrm{yr}^{-1}$ (Bellotti et al., 1995). These values are also consistent with the rates of vertical aggradation of floodplain, estimated between $7 \mathrm{~mm}$ and $15 \mathrm{~mm} \mathrm{yr}^{-1}$ and with the stacking pattern of channels. Channels are, in fact, narrower and vertically stacked one on top of the other, thus suggesting a very low rate of lateral migration. This tendency is reversed just below the $m f_{S}$ due to the decrease of the relative sealevel rise rate (1.5 to $1.7 \mathrm{~mm} \mathrm{yr}^{-1}$ ) (Bellotti et al., 1995) and, consequently, of the accommodation space that induces a reduction of the channel-fill thickness, and an increase in lateral amalgamation and width of the channels.

During the HST, the further decrease of accommodation space led the Tiber fluvial system to a reduction of the aggradation rate. This favoured a reduction of the floodplain aggradation rate $\left(2.8\right.$ to $\left.3.0 \mathrm{~mm} \mathrm{yr}^{-1}\right)$, an increase of channel sinuosity with lateral expansion of the meander belts, as well as an increase in the channel interconnection and, consequently, of channel clustering (Figs 18 to 20). Fluvial deposits are also characterized by the presence of rare peat layers, whereas the dry palaeosols rich in carbonate concretions, forming away from the areas of active fluvial erosion, are more developed.

\section{CONCLUSIONS}

The Late Pleistocene/Holocene Tiber delta succession represents the most recent and one of the best preserved high-frequency/low rank depositional sequences developed along the Latium continental margin of the Italian peninsula. It has been investigated by integrating the stratigraphy of ca 1200 wells and several data derived from sedimentological, microfaunistic, pollen and geochemical analyses that have constituted the robust database for the environmental and stratigraphic reconstruction. Eightyone calibrated radiocarbon dates were also utilized to better constrain the age of deposits, and of the main stratigraphic surfaces forming the framework of this sedimentary succession. All of these data were utilized to construct several correlation panels, the longest of which, $60 \mathrm{~km}$ long, shows the entire Tiber depositional sequence from the landward to seaward sectors, and where the lowstand systems tract (LST), transgressive systems tract (TST) and highstand systems tract (HST) are well-represented. This study confirms that the Tiber depositional sequence (TDS) shares many characteristics, in terms of stratigraphic and depositional architecture, found in other Late Pleistocene to Holocene deltaic and coastal successions of the Mediterranean area. This suggests that beyond the local factors, represented by tectonic uplift, volcanism and subsidence of the continental margin, the processes exerting major control on the stratigraphic architecture of the Tiber sedimentary succession are the glacio-eustatic sealevel fluctuations. The sedimentary history confirms a lithofacies distribution recording a passage from a wave-dominated estuary to a wavedominated delta. This evolution is characterized by: (i) alluvial plain formation and valley incision during the early LST; (ii) partial filling of the valley during the late LST; (iii) complete filling of the valley and rapid landward migration of barrier-lagoon-estuary systems during the TST; and (iv) progradation of a wave-dominated delta during the HST.

Some important elements discussed in this study relate to: (1) the genesis of the Tibermixed bedrock-alluvial valley that extends perpendicularly to the coastal plain and partially to the innermost portion of the shelf. This valley shows many of the characteristics recognized in other Quaternary valleys and in experimental studies, namely: (i) a basal valleyfill surface formed through multiple episodes of incision during relative sea-level fall and (ii) a downstream increase of depth and width of the valley during the base-level fall, and the subsequent base-level rise due to the lateral erosion of the valley walls and the contemporaneous deposition and filling (vertical aggradation) of it. (2) The different physical expressions of the Tiber depositional sequence boundary from landward to seaward, and its diachronous and 
composite character recording several processes working during its formation (Fig. 21). (3) The maximum depth reached by the Tiber early lowstand delta at the end of the sea-level fall; a depth different than that deduced from the eustatic curves, and strictly related to the relative sea-level fall and the gradient of the shelf. (4) The rearward position of the Tiber late lowstand delta with respect to the deposit of early LST that the present authors attribute to the different subsidence and tectonic uplift characterizing the outer shelf sector on one hand and the inner shelf/coastal margin on the other. ( $\forall)$ The change of the channel pattern and of the stacking pattern of fluvial deposits during the LST, TST and HST. This is characterized by a low-sinuosity/braided style during the early LST and partially during the late LST, evolving to a high-sinuosity/meandering style during the Transgressive and highstand systems tracts, reflecting the change in accommodation space and the change of shape, dimension and widening of the valley.

All of these features indicate that the Late Pleistocene/Holocene Tiber delta succession, even if deposited in a short period of time from a geological point of view, represents the result of close interaction between many autogenic and allogenic factors. However, global eustatic variations and sediment supply under the control of climatic changes can be considered to be the main factors responsible for the stratigraphic architecture of this sedimentary succession, which has been heavily modified by human activity only in the last 3000 years.

\section{ACKNOWLEDGMENTS}

Many individuals and organisations have supported research on the Tiber Delta. Financial support was provided by MIUR (Ministero Istruzione Università Ricerca), SAPIENZA University of Rome, CNR (Consiglio Nazionale delle Ricerche) and 'CARG Project' - Geological Map of Italy $1: 50000$. We are very grateful to the ANAS for the access to core data. We would like to thank the reviewers J. Shaw, L. Giosan, A. Amorosi, the editor (N. Mountney) and associate editor (D. Mohrig) for late LST critical reviews of the manuscript and for their advice and positive comments, which helped us to improve it. Finally, Salvatore Milli wants to thank Piero Bellotti who introduced him to the study of the Tiber delta several years ago.

\section{REFERENCES}

Acocella, V. and Funiciello, R. (2006) Transverse systems along the extensional Tyrrhenian margin of central Italy and their influence on volcanism. Tectonics, 25, TC2003. doi: 10.1020/2005TC001845.

Aguzzi, M., Amorosi, A., Colalongo, M.L., Ricci Lucchi, M., Rossi, V., Sarti, G. and Vaiani, S.C. (2007) Late Quaternary climatic evolution of the Arno coastal plain (Western Tuscany, Italy) from subsurface data. Sed. Geol., 202, 211-229.

Alessandro, V., Bartolini, C., Caputo, C. and Pranzini, E. (1990) Land use impact on Arno, Ombrone and Tiber deltas during historical times. In: Littoral 1990 (Eds R.E. Qnélennec, E. Ercolani and G. Michon), Eurocoast, Château-Gombert, Marseille (France) 9-13 July, 261-265.

Amenduni, G. (1884) Sulle opere di bonificazioni della plaga litoranea dell'Agro Romano che comprende le paludi e gli stagni di Ostia, Porto, Maccarese e delle terre vallive di Stracciacappa, Baccano, Pantano e Lago dei Tartari. Relazione del progetto generale 15/7/1880. Min. LL.PP. Eredi Botta, Roma, 1-36.

Amorosi, A. and Colalongo, M.L. (2005) The linkage between alluvial and coeval nearshore marine successions: evidence from the Late Quaternary record of the Po River Plain, Italy. In: Fluvial Sedimentology VII (Eds M.D. Blum, S.B. Marriott and S.F. Leclair), IAS Spec. Publ., 35, 257275.

Amorosi, A. and Milli, S. (2001) Late Quaternary depositional architecture of Po and Tevere river deltas (Italy) and worldwide comparison with coeval deltaic successions. Sed. Geol., 144, 357-375.

Amorosi, A., Colalongo, M.L., Fusco, F., Pasini, G. and Fiorini, F. (1999) Glacio-eustatic control of continentalshallow marine cyclicity from Late Quaternary deposits of the south-eastern Po Plain (Northern Italy). Quatern. Res., 52, 1-13.

Amorosi, A., Centineo, M.C., Colalongo, M.L., Pasini, G., Sarti, G. and Vaiani, S.C. (2003) Facies architecture and Latest Pleistocene-Holocene depositional history of the Po Delta (Comacchio area), Italy. J. Geol., 111, 39-56.

Amorosi, A., Colalongo, M.L., Fiorini, F., Fusco, F., Pasini, G., Vaiani, S.C. and Sarti, G. (2004) Palaeogeographic and palaeoclimatic evolution of the Po Plain from 150-ky core records. Global Planet. Change, 40, 55-78.

Amorosi, A., Centineo, M.C., Colalongo, M.L. and Fiorini, F. (2005) Millennial-scale depositional cycles from the Holocene of the Po Plain, Italy. Mar. Geol., 222-223, 718.

Amorosi, A., Sarti, G., Rossi, V. and Fontana, V. (2008) Anatomy and sequence stratigraphy of the late Quaternary Arno valley fill (Tuscany, Italy). In: Advances in Application of Sequence Stratigraphy in Italy (Eds A. Amorosi, B.U. Haq and L. Sabato), GeoActa Spec. Publ., 1, 55-66.

Amorosi, A., Rossi, V., Sarti, G. and Mattei, R. (2013) Coalescent valley fills from the late Quaternary record of Tuscany (Italy). Quatern. Int., 288, 129-138.

Anderson, J.B., Rodriguez, A., Abdulah, K., Kenneth, A.R., Fillon, R.H., Banfield, L., McKeown, H. and Wellner, J. (2004) Late Quaternary stratigraphic evolution of the northern Gulf of Mexico margin: a synthesis. In: Late Quaternary Stratigraphic Evolution of the Northern Gulf of Mexico Margin (Eds J.B. Anderson and R.H. Fillon), SEPM Spec. Publ., 79, 1-23. 
Arnoldus-Huyzendveld, A., Gioia, P., Mussi, M., Toniutti, P., Zampetti, D. and Zarlenga, F. (1993) Paleosuperficie esposta, concentrazione di industria litica e stratigrafia nella piana costiera di Maccarese (Roma). Il Quaternario, 6, 213-226.

Barber, D.C., Dyke, A., Hillaire-Marcel, C., Jennings, A.E., Andrews, J.T., Kerwin, M.W., Bilodeau, G., McNeely, R., Southon, J., Morehead, M.D. and Gagnon, J.M. (1999) Forcing of the cold event of 8,200 years ago by catastrophic drainage of Laurentide lakes. Nature, 400, 344-348.

Barberi, F., Buanasorte, G., Cioni, R., Fiordelisi, A., Foresi, L., Iaccarino, S., Laurenzi, M.A., Sbrana, A., Vernia, L. and Villa, I.M. (1994) Plio-Pleistocene geological evolution of the geothermal area of Tuscany and Lazio. Mem. Descrittive Cart. Geol. D'Ital., 49, 77-134.

Bard, E., Hamelin, B. and Delanghe-Sabatier, D. (2010) Deglacial meltwater pulse 1B andYounger Dryas sea levels revisited with boreholes at Tahiti. Science, 327, 12351237.

Barra, D., Bonaduce, G., Brancaccio, L., Cinque, A., Ortolani, F., Pagliuca, S. and Russo, F. (1992) Evoluzione olocenica della piana costiera del Fiume Sarno (Campania). Soc. Geol. Ital. Mem., 42, 255-267.

Belknap, D.F., Kraft, J.C. and Dunn, R.K. (1994) Transgressive valley-fill lithosomes: Delaware and Maine. In: Incised-Valley Systems: Origin and Sedimentary Sequences (Eds W. Dalrimple, R. Boyd and B.A. Zaitlin), SEPM Spec. Publ., 51, 303-320.

Bellotti, P. (2000) Il modello morfosedimentario dei maggiori delta tirrenici italiani. Boll. Soc. Geol. Ital., 119, 777-792.

Bellotti, P. and Tortora, P. (1996) I sedimenti sul fondale del delta del Fiume Tevere. Boll. Soc. Geol. Ital., 115, 449458.

Bellotti, P., Carboni, M.G., Milli, S., Tortora, P. and Valeri, P. (1989) La piana deltizia del Fiume Tevere: analisi di facies ed ipotesi evolutiva dall'ultimo lowstand glaciale all'attuale. Giorn. Geol., 51, 71-91.

Bellotti, P., Chiocci, F.L., Milli, S. and Tortora, P. (1993) Variabilità nel tempo della distribuzione granulometrica sui fondali del Delta del Tevere. Boll. Soc. Geol. Ital., 112, 143-153.

Bellotti, P., Chiocci, F.L., Milli, S., Tortora, P. and Valeri, P. (1994) Sequence stratigraphy and depositional setting of the Tiber delta: integration of high-resolution seismics, well logs, and archeological data. J. Sed. Res., B64, 416432.

Bellotti, P., Milli, S., Tortora, P. and Valeri, P. (1995) Physical stratigraphy and sedimentology of the late Pleistocene-Holocene Tiber Delta depositional sequence. Sedimentology, 42, 617-634.

Bellotti, P., Caputo, C., Davoli, L., Evangelista, S. and Valeri, P. (1999) Lineamenti morfologici e sedimentologici della piana deltizia del Fiume Ombrone (Toscana meridionale). Boll. Soc. Geol. Ital., 118, 141-147.

Bellotti, P., Caputo, C., Davoli, L., Evangelista, S., Garzanti, E., Pugliese, F. and Valeri, P. (2004) Morpho-sedimentary characteristics and Holocene evolution of the Ombrone river Delta (Southern Tuscany). Geomorphology, 61, 7190.

Bellotti, P., Calderoni, G., Carboni, M.G., Di Bella, L., Tortora, P., Valeri, P. and Zernitskaya, V. (2007) Late Quaternary landscape evolution of the Tiber River delta plain (Central Italy): new evidence from pollen data, biostratigraphy and 14C dating. Z. Geomorphol., 4, 505534.
Bellotti, P., Mattei, M., Tortora, P. and Valeri, P. (2009) Geoarchaeological investigations in the area of the imperial harbours of Rome. Méditerranée, 112, 51-58.

Bellotti, P., Calderoni, G., Di Rita, F., D’Orefice, M., D'Amico, C., Esu, D., Magri, D., Preite Martinez, M., Tortora, P. and Valeri, P. (2011) The Tiber river delta plain (central Italy): coastal evolution and implications for the ancient Ostia Roman settlement. Holocene, 21, 11051116.

Belluomini, G., Iuzzolini, P., Manfra, L., Mortari, R. and Zalaffi, M. (1986) Evoluzione recente del delta del Tevere. Geol. Romana, 25, 213-224.

Best, J.L., Ashworth, P.J., Bristow, C.S. and Roden, J. (2003) Three-dimensional sedimentary architecture of a large mid-channel sand braid bar, Jamuna River, Bangladesh. J. Sed. Res., 73, 516-530.

Bhattacharya, J.P. and Giosan, L. (2003) Wave-influenced deltas: geomorphological implications for facies reconstruction. Sedimentology, 50, 187-210.

Bigi, S., Beaubien, S.E., Ciotoli, G., D'ambrogi, C., Doglioni, C., Ferrante, V., Lombardi, S., Milli, S., Orlando, L., Ruggiero, L., Tartarello, M.C. and Sacco, P. (2014) Mantle-derived $\mathrm{CO}_{2}$ migration along active faults within an extensional basin margin (Fiumicino, Rome, Italy). Tectonophysics, 637, 137-149.

Blum, M.D. (1994) Genesis and architecture of incised valley fill sequences: a Late Quaternary example from the Colorado River, Gulf of Coastal Plasin in Texas. In: Siliciclastic Sequence Stratigraphy: Recent Developments and Applications (Eds P. Weimer and H.W. Posamentier), AAPG Mem., 58, 259-283.

Blum, M.D. and Aslan, A. (2006) Signatures of climate vs. sea-level change within incised valley-fill successions: quaternary examples from the Texas Gulf Coast. Sed. Geol., 190, 177-211.

Blum, M.D. and Price, D.M. (1998) Quaternary alluvial plain construction in response to interacting glacio-eustatic and climatic controls, Texas Gulf Costal Plain. In: Relative Role of Eustasy, Climate, and Tectonism in Continental Rocks (Eds K.W. Shanley and P.J. McCabe), SEPM Spec. Publ., 59, 31-48.

Blum, M.D. and Törnqvist, T.E. (2000) Fluvial response to climate and sea-level change: a review and look forward. Sedimentology, 47(Suppl. 1), 2-48.

Blum, M.D., Martin, J., Milliken, K. and Garvin, M. (2013) Paleovalley systems: insights from Quaternary analogs and experiments. Earth Sci. Rev., 116, 128-169.

Bohacs, K. and Suter, J. (1997) Sequence stratigraphic distribution of coaly rocks: fundamental controls and paralic examples. Am. Assoc. Petrol. Geol. Bull., 81, 1612-1639.

Bond, G., Showers, W., Cheseby, M., Lotti, R., Almasi, P., deMenocal, P., Priore, P., Cullen, H., Hajdas, I. and Bonani, G. (1997) A pervasive millennial-scale cycle in North Atlantic Holocene and glacial climates. Science, 278, 1257-1266.

Bordoni, P. and Valensise, G. (1998) Deformation of the 125 ka marine terrace in Italy: tectonic implications. In: Coastal Tectonics (Eds I.S. Stewart and C. Vita-Finzi), Geol. Soc. London Spec. Publ., 146, 71-110.

Bortoluzzi, G., Frascari, F., Guerzoni, S., Incremona, N., Ravloli, M. and Rovatti, G. (1982) Some sedimentological and chemical features of the seafloor in front of Tiber River. Geogr. Fis. Dinam. Quatern., 5, 120-128.

Boyd, R., Dalrymple, R. and Zaitlin, B.A. (1992) Classification of clastic coastal depositional environments. Sed. Geol., 80, 139-150. 
Boyd, R., Dalrymple, R.W. and Zaitlin, B.A. (2006) Estuarine and incised-valley facies models. In: Facies Models Revisited (Eds H.W. Posamentier and R.G. Walker), SEPM Spec. Publ., 84, 171-235.

Boyer, J., Duvail, C., Le Strat, P., Gensous, B. and Tesson, M. (2005) High resolution stratigraphy and evolution of the Rhône delta plain during postglacial time, from subsurface drilling data bank. Mar. Geol., 222-223, 267-298.

Bridge, J.S. (2003) Rivers and Floodplains: Forms, Processes and Sedimentary Record. Blackwell, Oxford, 491 pp.

Bridge, J.S. and Tye, R.S. (2000) Interpreting the dimensions of ancient fluvial channel bars, channels, and channel belts from wire-line logs and cores. Am. Assoc. Petrol. Geol. Bull., 84, 1205-1228.

Cantelli, A., Paola, C. and Parker, G. (2004) Experiments on upstream-migrating erosional narrowing and widening of an incisional channel caused by dam removal. Water Resour. Res., 40, W03304. doi:10.1029/2003WR002940.

Caputo, C., La Monica, G.B., Lupia Palmieri, E. and Pugliese, F. (1987) Physiographic characteristics and dynamics of the shores of Rome (Italy). In: Proceeding of the First International Conference on Geomorphology, Part I (Ed. V. Gardiner), pp. 1185-1198. Wiley, Chichester.

Catuneanu, O., Abreu, V., Bhattacharya, J.P., Blum, M.D., Dalrymple, R.W., Eriksson, P.G., Fielding, C.R., Fisher, W.L., Galloway, W.E., Gibling, M.R., Giles, K.A., Holbrook, J.M., Jordan, R., Kendall, C.G., St, C., Macurda, B., Martinsen, O.J., Miall, A.D., Neal, J.E., Nummedal, D., Pomar, L., Posamentier, H.W., Pratt, B.R., Sarg, J.F., Shanley, K.W., Steel, R.J., Strasser, A., Tucker, M.E. and Winker, C. (2009) Towards the standardization of sequence stratigraphy. Earth Sci. Rev., 92, 1-33.

Catuneanu, O., Galloway, W.E., Kendall, C.G., St, C., Miall, A.D., Posamentier, H.W., Strasser, A. and Tucker, M.E. (2011) Sequence stratigraphy: methodology and nomenclature. Newsl. Stratigr., 44, 173-245.

Cavinato, G.P. and De Celles, P.G. (1999) Extensional basins in the tectonically bimodal central Apennines fold-thrust belt, Italy: response to corner flow above a subducting slab in retrograde motion. Geology, 27, 955-958.

Cavinato, G.P., De Rita, D., Milli, S. and Zarlenga, F. (1992) Correlazione tra i principali eventi tettonici, sedimentari, vulcanici ed eustatici che hanno interessato l'entroterra (conche intrappenniniche) ed il margine costiero tirrenico laziale durante il Pliocene superiore ed il Pleistocene. Stud. Geol. Camerti, volume speciale 1992/1, 109-114.

Chappell, J. and Shackleton, N.J. (1986) Oxygen isotopes and sea level. Nature, 324, 137-140.

Chiocci, F.L. and Milli, S. (1995) Construction of a chronostratigraphic diagram for a high-frequency sequence: the $20 \mathrm{ky}$ B.P. to present Tiber depositional sequence. Il Quaternario, 8, 339-348.

Chiocci, F.L. and Normark, W.R. (1992) Effect of sea-level variation on upper-slope depositional processes offshore of Tiber delta, Tyrrhenian Sea, Italy. Mar. Geol., 104, 109-122.

Church, M. (2006) Bed material transport and the morphology of alluvial river channels. Annu. Rev. Earth Planet. Sci., 34, 325-354.

Church, K.D. and Gawthorpe, R.L. (1994) High resolution sequence stratigraphy of the late Namurian in the Widmerpool Gulf (east Midlands, U.K.). Mar. Petrol. Geol., 11, 528-544.

Cioni, R., Laurenzi, M.A., Sbrana, A. and Villa, I.M. (1993) ${ }^{40} \mathrm{Ar} /{ }^{39} \mathrm{Ar}$ chronostratigraphy of the initial activity in the Sabatini Volcanic Complex (Italy). Boll. Soc. Geol. Ital., 112, 251-263.
Clarke, G.K.C., Leverington, D.W., Teller, J.T. and Dyke, A.S. (2004) Paleohydraulics of the last outburst flood from glacial Lake Agasiz and the 8200 BP cold event. Quatern. Sci. Rev., 23, 389-407.

Cohen, K.M. and Gibbard, P. (2011) Global chronostratigraphical correlation table for the last 2.7 million years. Subcommission on Quaternary Stratigraphy (International Commission on Stratigraphy), Cambridge, UK.

Conato, V., Esu, D., Malatesta, A. and Zarlenga, F. (1980) New data on the Pleistocene of Rome. Quaternaria, 22, 131-176.

Cosentino, D., Cipollari, P., Di Bella, L., Esposito, A., Faranda, C., Giordano, G., Gliozzi, E., Mattei, M. and Mazzini, I. (2009) Tectonics, sea-level changes and paleoenvironments in the early Pleistocene of Rome (Italy). Quatern. Res., 72, 143-155.

Coutellier, V. and Stanley, D.J. (1987) Late Quaternary stratigraphy and paleogeography of the eastern Nile delta, Egypt. Mar. Geol., 77, 257-275.

Dade, W.B. (2000) Grain size, sediment transport and alluvial channel pattern. Geomorphology, 35, 119-126.

Dade, W.B. and Friend, P.F. (1998) Grain-size, sediment transport regime, and channel slope in alluvial rivers. J. Geol., 106, 661-675.

D'Agostino, N., Jackson, J., Dramis, F. and Funiciello, R. (2001) Interactions between mantle upwelling, drainage evolution and active normal faulting: an example from the central Apennines (Italy). Geophys. J. Int., 147, 475-497.

Dalrymple, R.W., Zaitlin, B.A. and Boyd, R. (1992) Estuarine facies models: conceptual basis and stratigraphic implications. J. Sed. Petrol., 62, 1130-1146.

Dalrymple, R.W., Baker, E.K., Harris, P.T. and Hughes, M.G. (2003) Sedimentology and stratigraphy of a tidedominated foreland-basin delta (Fly river, Papua New Guinea). In: Tropical Deltas of Southeast Asia, Sedimentology, Stratigraphy, and Petroleum Geology (Eds F.H. Sidi, D. Nummedal, P. Imbert, H. Darman and H.W. Posamentier), SEPM Spec. Publ., 76, 147-173.

Dan, S., Walstra, D.R., Stive, M.J.F. and Panin, N. (2011) Processes controlling the development of a river mouth spit. Mar. Geol., 280, 116-129.

De Rita, D., Funiciello, R., Corda, L., Sposato, A. and Rossi, U. (1993) Volcanic unit. In: Sabatini Volcanic Complex (Ed. M. Di Filippo), Consiglio Nazionale Delle Ricerche, Progetto Finalizzato "Geodinamica” Monografie Finali, 11, 33-79.

De Rita, D., Milli, S., Rosa, C., Zarlenga, F. and Cavinato, G.P. (1994) Catastrophic eruptions and eustatic cycles: example of Lazio volcanoes. Atti Conv. Lincei., 112, 135-142.

De Rita, D., Faccenna, C., Funiciello, R. and Rosa, C. (1995) Stratigraphy and volcano-tectonics. In: The Volcano of the Alban Hills (Ed. R. Trigila), Tipografia S.G.S, Roma, 33-71.

De Rita, D., Fabbri, M., Mazzini, I., Paccara, P., Sposato, A. and Trigari, A. (2002) Volcanoclastic sedimentation in coastal environments: the interplay between volcanismand Quaternary sea level changes (central Italy). Quatern. Int., 95-96, 141-154.

Demarest II, J.M. and Kraft, J.C. (1987) Stratigraphic record of Quaternary sea levels: implications for more ancient strata. In: Sea-Level Fluctuation and Coastal Evolution (Eds D. Nummedal, O.H. Pilkey and J.D. Howard), SEPM Spec. Publ., 41, 223-239.

Di Bella, L. (2010) Plio-Pleistocene foraminiferal assemblages of the Monte Mario site (Rome, Italy). Boll. Soc. Paleontol. Ital., 49, 145-161. 
Di Bella, L., Bellotti, P., Frezza, V., Bergamin, L. and Carboni, M.G. (2011) Benthic foraminiferal assemblages of the imperial harbor of Claudius (Rome): further paleoenvironmental and geoarcheological evidences. Holocene, 21, 1245-1259.

Di Bella, L., Bellotti, P. and Milli, S. (2013) The role of foraminifera as indicators of the Late Pleistocene-Holocene palaeoclimatic fluctuations on the deltaic environment: the example of Tiber delta succession (Tyrrhenian margin, Italy). Quatern. Int., 303, 191-209.

Di Rita, F. and Magri, D. (2012) An overview of the Holocene vegetation history from the central Mediterranean coasts. J. Mediterranean Earth Sci., 4, 3552.

Di Rita, F., Celant, A. and Magri, D. (2010) Holocene environmental instability in the wetland north of the Tiber delta (Rome, Italy): sea-lake-man interactions. $J$. Paleolimnol., 44, 51-67.

Di Rita, F., Celant, A., Milli, S. and Magri, D. (2015) Late glacial-early Holocene vegetation history of the Tiber delta (Rome, Italy) under the influence of climate change and sea level rise. Rev. Palaeobot. Palynol., 218, 204-216.

Díaz, J.I., Nelson, C.H., Barber Jr, J.H. and Giro, S. (1990) Late Pleistocene and Holocene sedimentary facies on the Ebro continental shelf. In: The Ebro Continental Margin, Northwestern Mediterranean (Eds C.H. Nelson and A. Maldonado ), Mar. Geol., 95, 333-352.

Doglioni, C., Innocenti, F., Morellato, C., Procaccianti, D. and Scrocca, D. (2004) On the Tyrrhenian sea opening. Mem. Descrittive Cart. Geol. Ital., 44, 147-164.

Dominguez, J.M.L. and Wanless, H.R. (1991) Facies architecture of a falling sea-level strandplain, Doce River coast, Brazil. In: Shelf Sand and Sandstone Bodies (Eds D.J.P. Swift, G.F. Oertel, R.W. Tillman and J.A. Thorne), IAS Spec. Publ., 14, 259-281.

Dominguez, J.M.L., Martin, L. and Bittencourt, A.C.S.P. (1987) Sea-level history and Quaternary evolution of river mouth-associated beach-ridge plains along the eastsoutheast Brazilian coast: a summary. In: Sea-Level Fluctuation and Coastal Evolution (Eds D. Nummedal, O.H. Pilkey and J.D. Howard), SEPM Spec. Publ., 41, 115-127.

Ercilla, G., Alonso, B. and Baraza, J. (1994) Post-Calabrian sequence stratigraphy of the northwestern Alboran Sea (southwestern Mediterranean). Mar. Geol., 120, 249265.

Ethridge, F.G., Wood, L.J. and Schumm, S.A. (1998) Cyclic variables controlling fluvial sequence development: problems and perspectives. In: Relative Role of Eustasy, Climate, and Tectonism in Continental Rocks (Eds K.W. Shanley and P.J. McCabe), SEPM Spec. Publ., 59, 17-29.

Evans, K.G., Stephens, A.W. and Shorten, G.G. (1992) Quaternary sequence stratigraphy of the Brisbane River delta, Moreton Bay, Australia. Mar. Geol., 107, 61-79.

Faccenna, C., Funiciello, R., Bruni, A., Mattei, M. and Sagnotti, L. (1994) Evolution of a transfer related basin: the Ardea basin (Latium, Central Italy). Basin Res., 5, 111.

Ferranti, L., Antonioli, F., Mauz, B., Amorosi, A., Dai Pra, G., Mastronuzzi, G., Monaco, C., Orru', P., Pappalardo, M., Radtke, U., Renda, P., Romano, P., Sanso', P. and Verrubbi, V. (2006) Markers of the last interglacial sealevel highstand along the coast of Italy: tectonic implications. Quatern. Int., 145-146, 30-54.

Fielding, C.R. and Gibling, M.R. (2005) Distinguishing between channel and valley fills: definitions, diagnostic criteria and dimensional data. 8th International Conference on Fluvial Sedimentology, Delft, The Netherlands, $101 \mathrm{pp}$.

Follieri, M., Magri, D. and Sadori, L. (1988) 250,000-year pollen record from Valle di Castiglione(Roma). Pollen Spores, 30, 329-356.

Fornaseri, M. (1985) Geochronology of volcanic rocks from Lazio (Italy). Rend. Soc. Ital. Min. Petr., 40, 73-106.

Fraccascia, S., Chiocci, F.L., Scrocca, D. and Falese, F. (2013) Very high-resolution seismic stratigraphy of Pleistocene eustatic minima markers as a tool to reconstruct the tectonic evolution of the northern Latium shelf (Tyrrhenian Sea, Italy). Geology, 41, 375-378.

Funiciello, R., Locardi, E. and Parotto, M. (1976) Lineamenti geologici dell'area sabatina orientale. Boll. Soc. Geol. Ital., 95, 831-849.

Gensous, B. and Tesson, M. (1996) Sequence stratigraphy, seismic profiles, and cores of Pleistocene deposits on the Rhône continental shelf. Sed. Geol., 105, 183-190.

Gensous, B. and Tesson, M. (1998) Postglacial deposits of the Rhône shelf (western Mediterranean): stratigraphic organization, sedimentary budget and preservation potential. Volume abstract 15th International Sedimentological Congress, Alicante, Spain, 374.

Gensous, B., Williamson, D. and Tesson, M. (1993) LateQuaternary transgressive and highstand deposits of a deltaic shelf (Rhône Delta, France). In: Sequence Stratigraphy and Facies Associations (Eds H.W. Posamentier, C.P. Summerhayes, B.U. Haq and G.P. Allen), IAS Spec. Publ., 18, 197-211.

Gibling, M.R. (2006) Width and thickness of fluvial channel bodies and valley fills in the geological record: a literature compilation and classification. J. Sed. Res., 76, 731-770.

Gibling, M.R., Saunders, K.I., Tibert, N.E. and White, J.A. (2004) Sequence set, high-accommodation events, and the coal window in the Carboniferous Sydney Coalfied, Atlantic Canada. In: Sequence Stratigraphy, Paleoclimate, and Tectonics of Coal-Bearing Strata (Eds J.C. Pashin and R.A. Gastaldo), AAPG Stud. Geol., 51, 169-197.

Giordano, G., Esposito, A., De Rita, D., Fabbri, M., Mazzini, I., Trigari, A., Rosa, C. and Funiciello, R. (2003) The sedimentation along the Roman coast between middle and upper Pleistocene: the interplay of eustatism, tectonics and volcanism - new data and review. Il Quaternario, 16, 121-129.

Giosan, L. (2007) Morphodynamic feedbacks on deltaic coasts: lessons from the wave dominated Danube delta. Proceedings of Coastal Sediments 2007. ASCE, New Orleans, USA, 828-841.

Giosan, L., Donnelly, J., Vespremeanu, E., Bhattacharya, J., Olariu, C. and Buonaiuto, F. (2005) River delta morphodynamics: examples from the danube delta. In: River Deltas: Concepts, Models, Examples (Eds L. Giosan and J.P. Bhattacharya), SEPM Spec. Publ., 83, 393-411.

Giraudi, C. (2004) Evoluzione tardo-olocenica del delta del Tevere. Il Quaternario, 17, 477-492.

Giraudi, C. (2011) The sediments of the 'Stagno di Maccarese'marsh (Tiber river delta, central Italy): a lateHolocene record of natural and human-induced environmental changes. Holocene, 21, 1233-1243.

Giraudi, C., Tata, C. and Paroli, L. (2009) Late Holocene evolution of Tiber River Delta and geoarchaeology of Claudius and Trajan Harbor, Rome. Geoarchaeology, 24, 371-382. 
Goiran, J.P., Tronchère, H., Salomon, F., Carbonel, P., Djerbi, H. and Ognard, C. (2009) Paleoenvironmental recontruction of the ancient harbors of Rome: Claudius and Trajan's marine harbors on the Tiber delta. Quatern. Int., 216, 3-13.

Hampson, G.H., Stollhofen, H. and Flint, S. (1999) A sequence stratigraphic model for the lower coal measures (Upper Carboniferous) of the Ruhr discrict, north-west Germany. Sedimentology, 46, 1197-1231.

Haq, B.U., Hardenbol, J. and Vail, P.R. (1988) Mesozoic and Cenozoic chronostratigraphy and cycles of sea-level change. In: Sea-Level Changes: An Integrated Approach (Eds C.K. Wilgus, B.S. Hastings, C.G.St.C. Kendall, H.W. Posamentier, C.A. Ross and J.C. Van Wagoner), SEPM Spec. Publ., 42, 71-108.

Hardenbol, J., Thierry, J., Farley, M.B., Jacquin, T., De Graciansky, P.C. and Vail, P.R. (1998) Mesozoic and Cenozoic sequence chronostratigraphic framework of European basins. In: Mesozoic and Cenozoic Sequence Stratigraphy of European Basins (Eds P.C. De Graciansky, J. Hardenbol, J. Thierry and P.R. Vail), SEPM Spec. Publ., 60, 3-13.

Helland-Hansen, W. and Martinsen, O.J. (1996) Shoreline trajectories and sequence: description of variable depositional-dip scenarios. J. Sed. Res., 66, 670-688.

Hernández-Molina, F.J., Somoza, L., Rey, J. and Pomar, L. (1994) Late Pleistocene-Holocene sediments on the Spanish continental shelves: model for very highresolution sequence stratigraphy. Mar. Geol., 120, 129-174.

Hernández-Molina, F.J., Somoza, L. and Rey, J. (1996) Late Pleistocene-Holocene high-resolution sequence analysis on the Alboran Sea continental shelf. In: Geology of Siliciclastic Shelf Seas (Eds M. De Batist and P. Jacobs), Geol. Soc. London Spec. Publ., 117, 139-154.

Holbrook, J.M. and Bhattacharya, J.P. (2012) Reappraisal of the sequence boundary in time and space: case and considerations for and SU (subaerial unconformity that is not a sediment bypass surface, a time barrier, or an unconformity). Earth Sci. Rev., 113, 271-302.

Incarbona, A., Di Stefano, E., Sprovieri, R., Bonomo, S. Pelosi, N. and Sprovieri, M. (2010) Millennial-scale paleoenvironmental changes in the central Mediterranean during the last interglacial: comparison with European and North Atlantic records. Geobios, 43, 111-122.

Jerrett, R.M., Flint, S.S., Davies, R.C. and Hodgson, D.M. (2011) Sequence stratigraphic interpretation of a Pennsylvanian (Upper Carboniferous) coal from the central Appalachian Basin, USA. Sedimentology, 58, 1180-1207.

Jouannic, G., Gillot, P.Y., Goiran, J.P., Lefevre, J.C., Siani, G. and Salomon, F. (2013) Tephrochronological study in the Maccarese lagoon (near Rome, Italy): identification of Holocene tephra layers. Quaternaire, 24, 65-74.

Karner, D.B., Marra, F. and Renne, P.R. (2001) The history of the Monti Sabatini and Alban Hills volcanoes: groundwork for assessing volcanic-tectonic hazards for Rome. J. Volcanol. Geoth. Res., 107, 185-219.

Labaune, C., Jouet, G., Berne', S., Gensous, B., Tesson, M. and Delpeint, A. (2005) Seismic stratigraphy of the deglacial deposits of the Rhône prodelta and of the adjacent shelf. Mar. Geol., 222-223, 299-311.

Lambeck, K., Yokoyama, Y. and Purcell, T. (2002) Into and out of the Last Glacial Maximum: sea-level change during oxygen isotope stages 3 and 2. Quatern. Sci. Rev., 21, 343360.
Lambeck, K., Antonioli, F., Purcell, A. and Silenzi, S. (2004) Sea-level change along the Italian coast for the past 10,000 yr. Quatern. Sci. Rev., 23, 1567-1598.

Lambeck, K., Antonioli, F., Anzidei, M., Ferranti, L., Leoni, G., Scicchitano, G. and Silenzi, S. (2011) Sea level change along the Italian coast during the Holocen and projections for the future. Quatern. Int., 232, 250-257.

Leclair, S.F. and Bridge, J.S. (2001) Quantitative interpretation of sedimentary structures formed by river dunes. J. Sed. Res., 71, 713-716.

Locardi, E., Lombardi, G., Funiciello, R. and Parotto, M. (1976) The main volcanic group of Lazio (Italy): relations between structural evolution and petrogenesis. Geol. Romana, 15, 279-300.

Loutit, T.S., Hardenbol, J., Vail, P.R. and Baum, G.R. (1988) Condensed sections: the key to age determination and correlation of continental margin sequences. In: Sea-Level Changes: An Integrated Approach (Eds C.K. Wilgus, B.S. Hastings, C.G. St. C. Kendall, H.W. Posamentier, C.A. Ross and J.C. Van Wagoner), SEPM Spec. Publ., 42, 183-213.

Lunt, I.A., Bridge, J.S. and Tye, R.S. (2004) A quantitative, three-dimensional depositional model of gravelly braided rivers. Sedimentology, 51, 377-414.

Malinverno, A. and Ryan, W.B.F. (1986) Extension in the Tyrrhenian Sea and shortening in the Apennines as a result of arc migration driven by sinking of the lithosphere. Tectonics, 5, 227-245.

Mancini, M. and Cavinato, G.P. (2005) The middle valley of the Tiber River, Central Italy: Plio-Pleistocene fluvial and coastal sedimentation, extensional tectonics and volcanism. In: Fluvial Sedimentology VII (Eds M.D. Blum, S.B. Marriott and S.F. Leclair), IAS Spec. Publ., 35, 373396.

Mancini, M., D'Anastasio, E., Barbieri, M. and De Martini, P.M. (2007) Geomorphological, paleontological and ${ }^{87} \mathrm{Sr} /{ }^{86} \mathrm{Sr}$ isotope analyses of early Pleistocene paleoshorelines to define the uplift of Central Apennines (Italy). Quatern. Res., 67, 487-501.

Mancini, M., Moscatelli, M., Stigliano, F., Cavinato, G.P., Milli, S., Pagliaroli, A., Simionato, M., Brancaleoni, R., Cipolloni, I., Coen, G., Di Salvo, C., Garbin, F., Lanzo, G., Napoleoni, Q., Scarapazzi, M., Storoni Ridolfi, S. and Vallone, R. (2013) The Upper Pleistocene-Holocene fluvial deposits of the Tiber River in Rome (Italy): lithofacies, geometries, stacking pattern and chronology. J. Mediterranean Earth Sci., 5, 95-101.

Mariani, M. and Prato, R. (1988) I bacini Neogenici costieri del margine tirrenico: approccio sismico-stratigrafico. Mem. Soc. Geol. Ital., 41, 519-531.

Marini, M., Milli, S., Rossi, M., De Tomasi, V., Meda, M. and Lisi, N. (2013) Multi-scale characterization of the Pleistocene-Holocene Tiber delta deposits as a depositional analogue for hydrocarbon reservoirs. J. Mediterranean Earth Sci., 5, 103-109.

Martin, J., Cantelli, A., Paola, C., Blum, M. and Wolinsky, M. (2011) Quantitative modeling of the evolution and geometry of incised valleys. J. Sed. Res., 81, 64-79.

Martinson, D.G., Pisias, N.G., Hayes, J.D., Imbrie, J., Moore, T.C. and Shackleton, N.J. (1987) Age dating and the orbital theory of the ice ages development of a highresolution 0 to 300,000 year chronostratigraphy. Quatern. Res., 27, 1-29.

Mayewski, P.A., Rohling, E.E., Stager, C., Karlen, K., Maasch, K., Meeker, L.D., Meyerson, E., Gasse, F., ven Kreveld, S., Holmgrem, K., Lee-Thorp, J., Rosqvist, G., 
Rack, F., Staubwasser, M. and Schneider, R. (2004) Holocene climate variability. Quatern. Res., 62, 243-255.

McBride, R.A., Anderson, L.C., Tudoran, A. and Roberts, H.H. (1999) Holocene stratigraphic architecture of a sandrich shelf and the origin of linear shoals: Northeastern Gulf of Mexico. In: Isolated Shallow Marine Sand Bodies: Sequence Stratigraphic Analysis and Sedimentologic Interpretation (Eds K.M. Bergman and J.W. Snedden), SEPM Spec. Publ., 64, 85-93.

Miall, A.D. (1991) Stratigraphic sequences and their chronostratigraphic correlation. J. Sed. Petrol., 61, 497505.

Miall, A.D. (2006) Reconstructing the architecture and sequence stratigraphy of a preserved fluvial record as a tool for reservoir development: a reality check. Am. Assoc. Petrol. Geol. Bull., 90, 989-1002.

Miller, K.G., Kominz, M.A., Browning, J.V., Wright, J.D., Mountain, G.S., Katz, M.E., Sugarman, P.J., Cramer, B.S., Christie-Blick, N. and Pekar, S.F. (2005) The Phanerozoic record of global sea-level change. Science, 310, 1293-1298.

Milli, S. (1994) High-frequency sequence stratigraphy of themiddle-late Pleistocene to Holocene deposits of the Roman Basin (Rome, Italy): relationships among highfrequency eustatic cycles, tectonics and volcanism. In: Second High-Resolution Sequence Stratigraphy Conference (Eds H.W. Posamentier and E. Mutti), Tremp, Spain, 2027 June.

Milli, S. (1997) Depositional setting and high-frequency sequence stratigraphy of the middle-upper Pleistocene to Holocene deposits of the Roman basin. Geol. Romana, 33, 99-136.

Milli, S., Moscatelli, M., Palombo, M.R., Parlagreco, L. and Paciucci, M. (2008) Incised valleys, their filling and mammal fossil record: a case study from Middle-Upper Pleistocene deposits of the Roman Basin (Latium, Italy). In: Advances in Application of Sequence Stratigraphy in Italy (Eds A. Amorosi, B.U. Haq and L. Sabato), GeoActa Spec. Publ., 1, 67-87.

Milli, S., D'Ambrogi, C., Bellotti, P., Calderoni, G., Carboni, M.G., Celant, A., Di Bella, L., Di Rita, F., Frezza, V., Magri, D., Pichezzi, R.M. and Ricci, V. (2013) The transition from wave-dominated estuary to wavedominated delta: the Late Quaternary stratigraphic architecture of Tiber deltaic succession (Italy). Sed. Geol., 284-285, 159-180.

Mitchum, R.M., Jr and Van Wagoner, J.C. (1991) Highfrequency sequences and their stacking pattern: sequence stratigraphy evidence of high-frequency eustatic cycles. Sed. Geol., 70, 131-170.

Morton, R.A. and Suter, J.R. (1996) Sequence stratigraphy and composition of Late Quaternary shelf-margin deltas, northern Gulf of Mexico. Am. Assoc. Petrol. Geol. Bull., 80, 505-530.

Nelson, H.F. (1970) Hydrography, sediment dispersal, and recent historical development of the Po river delta, Italy. In: Deltaic Sedimentation Modern and Ancient (Ed. J.P. Morgan), SEPM Spec. Publ., 15, 152-184.

Nichol, S.L., Boyd, R. and Penland, S. (1994) Stratigraphic response of wave-dominated estuaries to Ddfferent relative sea-level changes and sediment supply histories: Quaternary case studies from Nova Scozia, Louisiana and Eastern Australia. In: Incised-Valley Systems: Origin and Sedimentary Sequences (Eds R.W. Dalrymple, R. Boyd and B.A. Zaitlin), SEPM Spec. Publ., 51, 266-283.
Nichol, S.L., Boyd, R. and Penland, S. (1996) Sequence stratigraphy of a coastal-plain incised valley estuary: Lake Calcasieu, Louisiana. J. Sed. Res., 66, 847-857.

Nisi, M.F., Antonioli, F., Pra, G.D., Leon, G. and Silenzi, S. (2003) Coastal deformation between the Versilia and the Garigliano plains (Italy) since the last interglacial stage. J. Quatern. Sci., 18, 709-721.

Oomkens, E. (1970) Depositional sequences and sand distribution in the postglacial Rhône delta complex. In: Deltaic Sedimentation Modern and Ancient (Ed. J.P.E. Morgan), SEPM Spec. Publ., 15, 198-212.

Ortolani, F. and Pagliuca, S. (1999) Evoluzione geologica e geomorfologica olocenica e problemi geoambientali delle pianure costiere antropizzate della Campania. Giorn. Geol., 61, 73-75.

Patacca, E., Sartori, R. and Scandone, P. (1990) Tyrrhenian basin and apenninic arcs kinematic relations since Late Tortonian times. Mem. Soc. Geol. Ital., 45, 425-451.

Peakall, J., Ashworth, P.J. and Best, J.L. (2007) Meanderbend evolution, alluvial architecture, and the role of cohesion in sinuous river channels: a flume study. J. Sed. Res., 77, 197-212.

Peccerillo, A. (2005) Plio-Quaternary Volcanism in Italy. Petrology, Geochemistry, Geodynamics. Springer, Heidelberg.

Peltier, W.R. and Fairbanks, R.G. (2006) Global glacial ice volume and last glacial maximum duration from an extended Barbados sea level record. Quatern. Sci. Rev., 25, 3322-3337.

Penland, S., Boyd, R. and Suter, J.R. (1988) Transgressive depositional systems of the Mississippi delta plain: a model for barrier shoreline and shelf sand development. J. Sed. Petrol., 58, 932-949.

Plint, A.G. (1988) Sharp-based shoreface sequences, and "offshore bars" in the Cardium Formation of Alberta: their relationships to relative changes in sea level. In: Sea Level Changes: An Integrated Approach (Eds C.K. Wilgus, B.S. Hastings, C. G. St. C. Kendall, H.W. Posamentier, C.A. Ross and J.C. Van Wagoner), SEPM Spec. Publ., 42, 357-370.

Posamentier, H.W. and Allen, G.P. (1999) Siliciclastic sequence stratigraphy - concepts and applications. SEPM Concepts Sedimentol. Paleontol., 7, 210.

Rampino, M.R. and Sanders, J.E. (1980) Holocene transgression in south-central Long Island, New York. J. Sed. Petrol., 50, 1063-1080.

Reading, H.G. and Collinson, J.D. (1996) Clastic coasts. In: Sedimentary Environments: Processes, Facies and Stratigraphy (Ed. H.G. Reading), pp. 154-231. Blackwell Science, Oxford.

Reijenstein, H.M., Posamentier, H.W. and Bhattacharya, J.P. (2011) Seismic geomorphology and high-resolution seismic stratigraphy of inner-shelf, fluvial, estuarine, deltaic, and marine sequences, Gulf of Thailand. Am. Assoc. Petrol. Geol. Bull., 95, 1959-1990.

Robert, H.H. and Sydow, J. (2003)Late Quaternary stratigraphy and sedimentology of the offshore Mahakam delta, east Kalomantan (Indonesia). In:Tropical Deltas of Southeast Asia: Sedimentology, Stratigraphy, and Petroleum Geology (Eds F.H. Sidi, D. Nummedal, P. Imbert, H. Darman and H.W. Posamentier), SEPM Spec. Publ., 76, 125-145.

Roy, P.S. (1994) Holocene estuary evolution-stratigraphic studies from southern Australia. In: Incised-Valley Systems: Origin and Sedimentary Sequences (Eds W. 
Dalrymple, R. Boyd and B.A. Zaitlin), SEPM Spec. Publ., 51, 241-263.

Russo Ermolli, E. and di Pasquale, G. (2002) Vegetation dynamics of south-western Italy in the last $28 \mathrm{kyr}$ inferred from pollen analysis of a Tyrrhenian Sea core. Veg. Hist. Archaeobot., 11, 211-219.

Saito, Y. (1994) Shelf sequence and characteristic bounding surfaces in a wave-dominated setting: latest PleistoceneHolocene examples from Northeast Japan. Mar. Geol., 120, 105-127.

Schumm, S.A. (1993) River response to base level change: implications for sequence stratigraphy. J. Geol., 101, 279294.

Sestini, G. (1989) Nile Delta: a review of depositional environments and geological history. In: Deltas: Sites and Traps for Fossil Fuels (Eds M.K.G. Whateley and K.T. Pickering), Geol. Soc. London Spec. Publ., 41, 99-127.

Shackleton, N.J. (1995) New data on the evolution of Pliocene climatic variability. In: Paleoclimate and Evolution, with Emphasis on Human Origins (Eds E.S. Vrba, G.H. Denton, T.C. Partridge and L.H. Burckle), pp. 242-248. Yale University Press, New Haven, Connecticut.

Shanley, K.W. and McCabe, P.J. (1994) Perspectives on the sequence stratigraphy of continental strata: report of a working group at the 1991 NUNA conference on high resolution sequence stratigraphy. Am. Assoc. Petrol. Geol. Bull., 74, 544-568.

Sheets, B.A., Paola, C. and Kelberer, J.M. (2007) Creation and preservation of channel-form sand bodies in an experimental alluvial system. In: Sedimentary Processes, Environments and Basins - Tribute to Peter Friend (Eds G.J. Nichols, E. Williams and C. Paola), IAS Spec. Publ., 38, 555-657.

Somoza, L., Barnolas, A., Arasa, A., Maestro, A., Rees, J.G. and Hernandez-Molina, F.J. (1998) Architectural stacking pattern of the Ebro delta controller by Holocene highfrequency eustatic fluctuation, delta-lobe switching and subsidence processes. Sed. Geol., 117, 11-32.

Stanley, D.J. and Warne, A.G. (1994) Worldwide initiation of Holocene marine deltas by deceleration of sea level rise. Science, 265, 228-231.

Strong, N. and Paola, C. (2009) Valleys that never were: time surfaces versus stratigraphic surfaces. J. Sed. Res., 78, 579-593.

Suter, R.J., Berryhill Jr, H.L. and Penland, S. (1987) Late Quaternary sea-level fluctuations and depositional sequences, southwest Louisiana continental shelf. In: SeaLevel Fluctuation and Coastal Evolution (Eds D. Nummedal, O.H. Pilkey and J.D. Howard), SEPM Spec. Publ., 41, 199-219.

Sydow, J. and Roberts, H.H. (1994) Stratigraphic framework of a Late Pleistocene shelf-edge delta, northeast Gulf of Mexico. Am. Assoc. Petrol. Geol. Bull., 78, 1276-1312.
Tal, M. and Paola, C. (2007) Dynamic single-thread channels maintained by the interaction of flow and vegetation. Geology, 35, 347-350.

Tarragoni, C., Bellotti, P., Davoli, L., Petronio, B.M. and Pietroletti, M. (2011) Historical and recent environmental changes of the Ombrone Delta (southern Italy). J. Coast. Res. Spec. Issue, 61, 344-352.

Tesson, M., Gensous, B., Allen, G.P. and Ravenne, C. (1990) Late Quaternary deltaic lowstand wedges on the Rhône continental shelf, France. Mar. Geol., 91, 325-332.

Tesson, M., Allen, G.P. and Ravenne, C. (1993) Late Pleistocene shelf-perched lowstand wedges on the Rhône continental shelf. In: Sequence Stratigraphy and Facies Associations (Eds H.W. Posamentier, C.P. Summerhayes, B.U. Haq and G.P. Allen), IAS Spec. Publ., 18, 183-196.

Thom, B.G. (1983) Transgressive and regressive stratigraphies of coastal sand barriers in southeast Australia. Mar. Geol., 56, 137-158.

Thom, B.G. and Roy, P.S. (1985) Relative sea levels and coastal sedimentation in southeast Australia in the Holocene. J. Sed. Petrol., 55, 257-264.

Thomas, M.A. and Anderson, J.B. (1994) Sea-level controls on the facies architecture of the Trinity/Sabine incisedvalley system, Texas continental shelf. In: Incised-Valley Systems: Origin and Sedimentary Sequences (Eds W. Dalrymple, R. Boyd and B.A. Zaitlin), SEPM Spec. Publ., 51, 63-82.

Torres, J., Savoye, B. and Cochonat, P. (1995) The effects of Late Quaternary sea-level changes on the Rhône slope sedimentation (northwestern Mediterranean), as indicated by seismic stratigraphy. J. Sed. Res., 65, 368-387.

Tortora, P. (1995) La superficie deposizionale del delta sottomarino del Tevere: zonazione del sedimento e processi associati. Boll. Soc. Geol. Ital., 113, 89-105.

Van Asselen, S. (2011) The contribution of peat compaction to total basin subsidence: implications for the provision of accommodation space in organic-rich deltas. Basin Res., 23, 239-255.

Van Maren, D.S. (2005) Barrier formation on an actively prograding delta system: the Red River delta, Vietnam. Mar. Geol., 224, 123-143.

Wright, V.P. and Marriott, S.B. (1993) The sequence stratigraphy of fluvial depositional systems: the role of floodplain sediment storage. Sed. Geol., 86, 203-210.

Yoo, D.G. and Park, S.C. (2000) High-resolution seismic study as a tool for sequence stratigraphic evidence of high-frequency sea-level changes: latest PleistoceneHolocene example from the Korea Strait. J. Sed. Res., 70, 296-309.

Manuscript received 12 April 2015; revision accepted 23 February 2016 